Colección Estándares del Sistema Interamericano de Derechos Humanos: miradas complementarias desde la academia

\title{
LOS DERECHOS DE LOS PUEBLOS
} INDÍGENAS Y TRIBALES EN LOS SISTEMAS DE DERECHOS HUMANOS

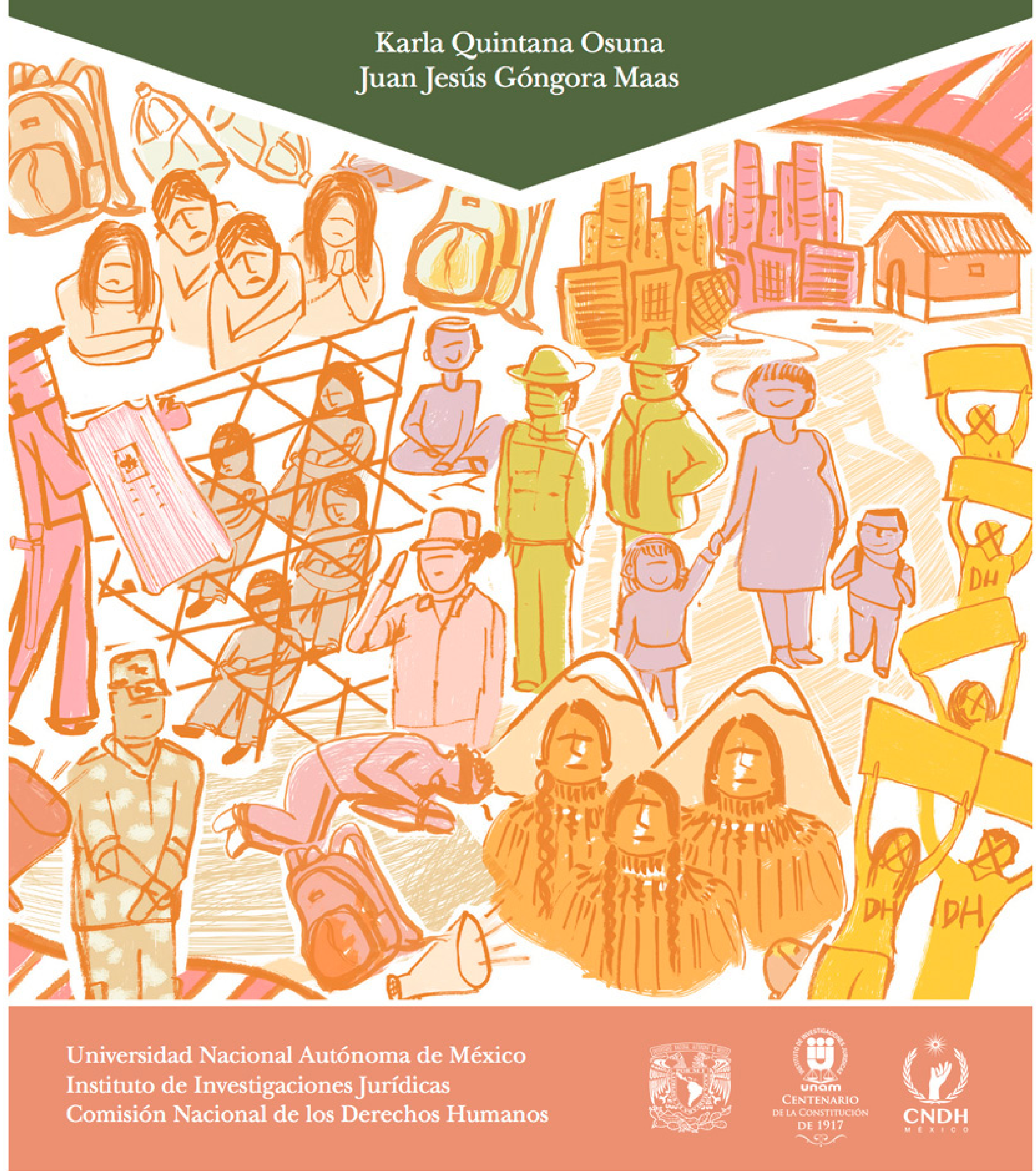


LOS DERECHOS DE LOS PUEBLOS INDÍGENAS Y TRIBALES EN LOS SISTEMAS DE DERECHOS HUMANOS 
Colección Estándares del Sistema Interamericano de Derechos Humanos: miradas complementarias desde la academia, Núm. 6

\author{
COORDINACIÓN EDITORIAL \\ IIJ-UNAM \\ CENADEH-CNDH \\ Lic. Raúl Márquez Romero \\ Secretario Técnico \\ Lic. Wendy Vanesa Rocha Cacho \\ Jefa del Departamento de Publicaciones \\ Lic. Miguel Ángel Ortiz Buendía \\ Director de Publicaciones \\ Eugenio Hurtado Márquez \\ Director Editorial
}

Edna María López García

Diana Luján Verón

Cuidado de la edición

Carlos Acevedo R.

Formación en computadora

José Antonio Bautista Sánchez

Diseño de interiores

Aramxa Guillén Sánchez

Diseño y elaboración del forro 


\section{KARLA I. QUINTANA OSUNA JUAN JESÚS GÓNGORA MAAS}

\section{LOS DERECHOS \\ DE LOS PUEBLOS INDÍGENAS \\ $Y$ TRIBALES EN LOS SISTEMAS DE DERECHOS HUMANOS}
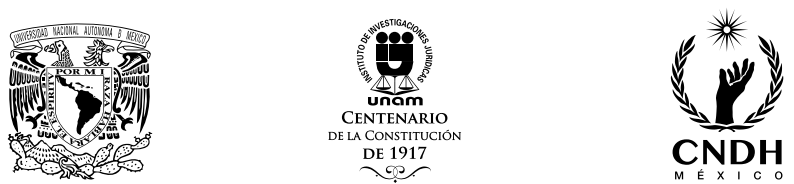

UNIVERSIDAD NACIONAL AUTÓNOMA DE MÉXICO INSTITUTO DE INVESTIGACIONES JURÍDICAS COMISIÓN NACIONAL DE LOS DERECHOS HUMANOS MÉXICO, 2017 
Esta colección es el resultado del proyecto editorial del Observatorio del Sistema Interamericano de Derechos Humanos del Instituto de Investigaciones Jurídicas de la UNAM.

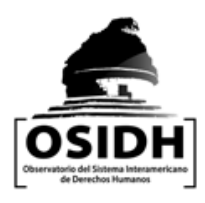

El contenido y las opiniones expresadas en el presente trabajo son responsabilidad exclusiva de sus autores y no necesariamente reflejan el punto de vista de la Comisión Nacional de los Derechos Humanos.

Primera edición: septiembre de 2017

DR (C) 2017. Universidad Nacional Autónoma de México INSTITUTO DE INVESTIGACIONES JURÍDICAS

Circuito Maestro Mario de la Cueva $s / n$

Ciudad de la Investigación en Humanidades

Ciudad Universitaria, C. P. 04510 Ciudad de México

DR (C) 2017. Comisión Nacional de los Derechos Humanos Periférico Sur 3469, Col. San Jerónimo Lídice

Delegación Magdalena Contreras, C. P. 10200 Ciudad de México

Impreso y hecho en México

ISBN: 978-607-729-350-7 (Obra completa)

ISBN: 978-607-729-357-6 (Cuaderno núm. 6) 


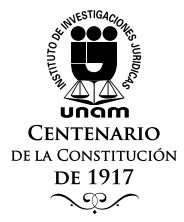

INSTITUTO DE INVESTIGACIONES JURÍDICAS

\author{
Director \\ Pedro Salazar Ugarte \\ Secretario Académico \\ Francisco Ibarra Palafox \\ Secretario Técnico \\ Raúl Márquez Romero
}

Jefa del Departamento de Publicaciones

Wendy Vanesa Rocha Cacho 


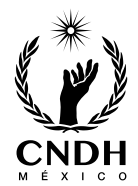

COMISIÓN NACIONAL DE LOS DERECHOS HUMANOS

Presidente

Luis Raúl González Pérez

Consejo Consultivo

Mariclaire Acosta Urquidi

María Ampudia González

Alberto Manuel Athié Gallo

Mariano Azuela Güitrón

Ninfa Delia Domínguez Leal

Mónica González Contró

David Kershenobich Stalnikowitz

Carmen Moreno Toscano

María Olga Noriega Sáenz

Guillermo I. Ortiz Mayagoitia 


\section{CONTENIDO}

PRESENTACIÓN $\ldots \ldots \ldots \ldots \ldots \ldots \ldots \ldots \ldots \ldots \ldots \ldots \ldots$ XI

INTRODUCCIÓN $\ldots \ldots \ldots \ldots \ldots \ldots \ldots \ldots \ldots \ldots$

\section{SISTEMA INTERAMERICANO DE DERECHOS HUMANOS}

1. Reconocimiento de la propiedad comunal: obligaciones de delimitar, demarcar, titular, sanear y consultar a los pueblos indígenas y tribales $\ldots \ldots \ldots \ldots \ldots 6$

A. Obligación de delimitación, demarcación y titulación $\quad 10$

B. Obligación de saneamiento . . . . . . . . . . . 20

C. Derecho/obligación de consulta . . . . . . . . 21

2. Vida digna $\ldots \ldots \ldots \ldots \ldots \ldots \ldots \ldots \ldots \ldots \ldots$

3. Discriminación $\ldots \ldots \ldots \ldots \ldots \ldots \ldots \ldots \ldots$

4. Libertad de consciencia y religión . . . . . . . . . . 41

5. Derecho de participación política . . . . . . . . 44

6. Mujeres indígenas $\ldots \ldots \ldots \ldots \ldots \ldots \ldots \ldots 48$

7. Desplazamiento forzado . . . . . . . . . . . . 49

8. Personalidad jurídica de los miembros y pueblos indígenas y tribales . . . . . . . . . . . . 52 
9. Otros temas sustantivos: integridad cultural, uso del idioma e identidad cultural . . . . . . . . . . . . 55

10. Medidas de protección $\ldots \ldots \ldots \ldots \ldots \ldots$

II. SISTEMA AFRICANO DE DERECHOS HUMANOS

1. Caso Endorois vs. Kenia $\ldots \ldots \ldots \ldots \ldots$

2. Caso Ogoni vs. Nigeria $\ldots \ldots \ldots \ldots \ldots \ldots \ldots$

3. Caso Ogiek vs. Kenia $\ldots \ldots \ldots \ldots \ldots \ldots \ldots$

III. SISTEMA EUROPEO DE DERECHOS HUMANOS

IV. SISTEMA UNIVERSAL DE DERECHOS HUMANOS

1. Comité de Derechos Humanos de la Organización de las Naciones Unidas: . . . . . . . . . . . . . . . 82 A. Casos . . . . . . . . . . . . . . . . 82 B. Observaciones Generales $\ldots \ldots \ldots \ldots \ldots .90$

2. Comité de Derechos Económicos, Sociales y Culturales: 93 Observaciones Generales . . . . . . . . . . . . . 93

3. Otros Comités. . . . . . . . . . . . . . . . . . 99

4. Relatoría Especial sobre los Derechos de los Pueblos Indígenas . . . . . . . . . . . . . . . . . . . 101

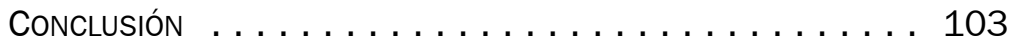

Bibliografía . . . . . . . . . . . . . . . . . . 105 


\section{PRESENTACIÓN}

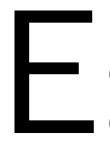

n la actualidad es indiscutible que, en la protección de los derechos humanos, no basta con hacer referencia a tratados internacionales en la materia. Por suerte, cada vez se acude con mayor intensidad al uso de jurisprudencia producida por organismos internacionales como una fuente adicional para fundamentar dicha protección. De esta forma, la jurisprudencia ha adquirido un nuevo papel en el sistema de fuentes a nivel nacional e internacional.

La producción de jurisprudencia es resultado de la labor de las y los jueces que, desde los pronunciamientos que hacen en los casos que se someten a su conocimiento, interpretan los instrumentos internacionales (tratados, convenciones y otras fuentes del derecho internacional), aportando una gran variedad de criterios para la mejor protección de la dignidad, la igualdad y los derechos humanos.

La existencia de una serie de principios y valores universales, así como de marcos jurídicos de naturaleza similar, ha permitido que la jurisprudencia que se genere en un ámbito regional o en un contexto nacional, sea retomada por otros tribunales. A esta dinámica o proceso de intercambio, que ha sido denominada de múltiples maneras, se le conoce como diálogo jurisprudencial. Como sostiene Irene Spigno, con independencia de los matices que hay entre las diferentes expresiones de este fenómeno, el mismo consiste

en la ampliación, explícita -es decir mediante una referencia textual a decisiones o técnicas argumentativas de otro juez perteneciente a un ordenamiento jurídico diverso- e implícita, 
del espectro de parámetros interpretativos y argumentativos a los cuales el juez recurre en el procedimiento de asignación de significado a un cierto enunciado normativo, de ponderación y de argumentación de las decisiones. ${ }^{1}$

Uno de los espacios en los cuales se produce una amplia jurisprudencia es en los sistemas regionales de protección (el interamericano, el europeo y el africano). La revisión de casos resueltos en estos sistemas permite constatar que la producción y uso de jurisprudencia ha permitido el fortalecimiento de la protección de los derechos fundamentales, siendo ésta una de las razones de su relevancia.

Ahora bien, reconocer el valor de la jurisprudencia no supone pasar por alto la complejidad de retomarla, principalmente en función de los múltiples tribunales que la producen y de que en muchos casos no la sistematizan, lo que vuelve necesaria su búsqueda caso por caso. Frente a este escenario, se consideró útil impulsar una iniciativa de sistematización de jurisprudencia de organismos regionales y tribunales nacionales.

La Colección Estándares del Sistema Interamericano de Derechos Humanos: miradas complementarias desde la academia, en tanto iniciativa del Observatorio del Sistema Interamericano de Derechos Humanos de la Universidad Nacional Autónoma de México y la Comisión Nacional de los Derechos Humanos $(\mathrm{CNDH})$, pone el énfasis en la sistematización, de manera especial pero no exclusiva, de la jurisprudencia producida por dicho sistema regional.

1 Spigno, Irene, “El diálogo entre Europa y América Latina. El estudio comparado de los casos líderes de la Corte IDH y el Tribunal EDH”, Ríos Vega, Luis Efrén y Spigno, Irene (Directores), Estudios de casos, líderes interamericanos y europeos, Vol. I. Libertad religiosa/ Libertad de expresión/ Derechos económicos, sociales y culturales/ Derechos de las personas desaparecidas, 2016, México, Tirant lo Blanch, p. 6. 
Sin desconocer que la Corte Interamericana de Derechos Humanos tiene su propia Colección de Jurisprudencia, ${ }^{2}$ además de Boletines Jurisprudenciales, ${ }^{3}$ en un ánimo de no duplicar, se pensó en desarrollar otra iniciativa editorial que fuera complementaria.

Que la Colección se desarrolle desde la academia, permitió incluir otros elementos que hacen de este proyecto un verdadero aporte en la sistematización de la jurisprudencia, tales como incorporar los estándares de la Comisión Interamericana y de otros sistemas de protección, e incluso jurisprudencia de Tribunales Constitucionales; análisis y problematización de la producción jurisprudencial; poner énfasis en la visión pragmática, es decir, abordar cómo podría darse la implementación práctica de los estándares, además de una evaluación de los retos por venir y, de esa forma, los temas pendientes en el Sistema Interamericano.

Es importante poner énfasis en que -sin desconocer el valor de la jurisprudencia, y en ese sentido, de los estándares desarrollados por la Corte Interamericana de Derechos Humanos, es indiscutible- las decisiones de la Comisión Interamericana también se consideran un referente obligado para la protección de los derechos humanos en sede nacional. Por esa razón, la Colección ha puesto énfasis en considerar, también, a este tipo de decisiones.

La Colección incluye siete Cuadernos, cada uno sobre un tema diferente, los cuales fueron seleccionados a partir de la revisión de las decisiones recientes de los dos órganos que for-

2 Véase Cuadernillos de Jurisprudencia de la Corte Interamericana de Derechos Humanos, Consúltese en http://www.corteidh.or.cr/index.php/es/al-dia/ publicaciones

${ }^{3}$ Para consultarlos acceder a http://www.corteidh.or.cr/index.php/es/al-dia/ publicaciones 
man parte el Sistema Interamericano de Derechos Humanos y de su relevancia para el escenario mexicano.

Queremos agradecer de manera especial a las personas que participaron en la escritura de los cuadernos que integran esta colección, reconociendo que su calidad de especialistas en los temas que abordaron garantiza un análisis exhaustivo, a profundidad y con alto rigor académico.

La Colección es una iniciativa del Observatorio del Sistema Interamericano de Derechos Humanos de la Universidad Nacional Autónoma de México y de la Comisión Nacional de los Derechos Humanos, a través del Centro Nacional de Derechos Humanos.

Esperamos que esta Colección sea una herramienta a nivel nacional para que las decisiones judiciales, administrativas y de política pública en todos los órdenes de gobierno, estén permeadas por los estándares internacionales que en materia de derechos humanos se han desarrollado, coadyuvando en la garantía plena de estos derechos.

\section{Dr. Pedro Salazar Ugarte Lic. Luis Raúl González Pérez Director IIJ-UNAM Presidente de la CNDH}




\section{INTRODUCCIÓN}

I reconocimiento de los derechos de los pueblos indígenas y tribales en los diferentes sistemas de derechos humanos y en las diversas constituciones nacionales ha tenido un largo camino. Tuvieron que pasar varias décadas, diversos movimientos y coyunturas para que dichos derechos fueran, poco a poco y no sin tensiones, reconocidos por los estados, tanto en el ámbito internacional como constitucional. Existen razones históricas, jurídicas, sociológicas y económicas para ello que exceden este trabajo, sin embargo, basta con recordar que muchos pueblos indígenas y tribales actualmente ocupan, o han sido desplazados, de territorios ricos en recursos naturales que son objeto de interés empresarial, y que en la gran mayoría de los países, los pueblos indígenas se encuentran inmersos en un contexto de discriminación estructural que impide o dificulta el reconocimiento de sus derechos.

Después de la Segunda Guerra Mundial, los primeros instrumentos internacionales de derechos humanos plasmaron una visión eurocéntrica respecto de los pueblos indígenas y tribales. Poco a poco, con la intervención directa de éstos, el gradual reconocimiento en los diferentes instrumentos internacionales y el desarrollo jurisprudencial, han dado mayor contenido y alcance a sus derechos.

Si bien existen diversas declaraciones y tratados que han reconocido paulatinamente los derechos de los pueblos indígenas 
y tribales, no se puede entender el desarrollo internacional del reconocimiento de esos derechos sin tener en cuenta, por un lado, el Convenio No. 169 de la Organización Internacional del Trabajo, que constituye un tratado internacional fundamental en el reconocimiento de derechos colectivos de los pueblos indígenas, con 22 ratificaciones, ${ }^{1}$ y por otro, analizar el Sistema Interamericano de Protección de Derechos Humanos, cuya jurisprudencia es, en el sistema internacional y regional, el que ha tenido mayores avances en dicho reconocimiento.

Tanto los informes de la Comisión Interamericana de Derechos y las sentencias de la Corte Interamericana de Derechos Humanos son referencia obligada, en especial, en el derecho de consulta previa, libre e informada, que tienen los pueblos indígenas respecto de su territorio. La sentencia de los Doce clanes Saramaka vs. Surinam (Caso del pueblo Saramaka) fue la primera sentencia a nivel internacional en referirse expresamente al derecho de consulta - y con ello a sus salvaguardas - de los pueblos indígenas y tribales, y ha aportado importantes estándares en la materia ${ }^{2}$ que han sido retomados por otros organismos internacionales. ${ }^{3}$

El reconocimiento en derechos de los pueblos indígenas y tribales no se ha limitado al derecho de consulta ni a los territorios - aunque sí ha tenido un especial acento-, sino que se ha extendido a otros conflictos de territorio y a diversas violaciones a sus derechos como pueblos y como individuos.

1 Información en http://www.ilo.org/dyn/normlex/es/f?p=NORMLEXPUB:11 300:0::NO::P11300_INSTRUMENT_ID:312314.

2 No podemos dejar del lado que algunos de esos estándares han sido criticados por los pueblos indígenas por considerarlos limitados.

3 Véase, por ejemplo, Comisión Africana de Derechos Humanos y de los Pueblos (Comisión ADHP), Centre for Minority Rights Development (Kenya) and Minority Rights Group International on behalf of Endorois Welfare Council vs. Kenya, 25 de noviembre de 2009. 
El presente trabajo destacará los principales temas en reconocimiento de derechos de pueblos indígenas que han sido desarrollados por los sistemas regionales y el sistema universal de protección de los derechos humanos. Es importante mencionar que hemos delimitado este trabajo al derecho internacional y no hemos hecho referencia al reconocimiento de dichos derechos por parte de los tribunales constitucionales, ${ }^{4}$ algunos de los cuales tienen importantes desarrollos y a los cuales han recurrido varios de los organismos internacionales a los que nos referiremos.

${ }^{4}$ Por ejemplo: Bolivia: Constitución Política del Estado Plurinacional de Bolivia (artículo 30.II.15), ley No. 3058 (19 de mayo de 2005) y el Decreto Supremo No. 29033 (16 de febrero de 2007); Colombia: Constitución Política de Colombia (artículo 330), Ley General Ambiental de Colombia (No. 99, 22 de diciembre de 1993) y el decreto No. 4633 ( 9 de diciembre de 2011); Ecuador: Corte Constitucional de Ecuador, Caso de los Pantanos Secos de Pastaza, No. 222-2004-RA, Sentencia del 9 de junio de 2004, Considerando Décimo Segundo; Guatemala: Corte de Constitucionalidad, Guatemala, 21 de diciembre de 2009, apelación de sentencia de amparo, Expte. 3878-2007, apartado; Perú: Sentencia del Tribunal Constitucional, Expte. No. 03343-2007-PA/TC, párr. 30. Véase en el mismo sentido: Corte IDH, Caso Pueblo Indígena Kichwa de Sarayaku vs. Ecuador. Fondo y reparaciones. Sentencia del 27 de junio de 2012. Serie C, No. 245, párr. 164. 
Este libro forma parte del acervo de la Biblioteca Jurídica Virtual del Instituto de Investigaciones Jurídicas de la UNAM

\section{SISTEMA INTERAMERICANO DE DERECHOS HUMANOS ${ }^{5}$}

I presente capítulo está dividido en diferentes subtemas
que resultan ser, en nuestro criterio, los más destacados
para tener una visión general y descriptiva del desarrollo del reconocimiento de derechos de los pueblos indígenas por parte de los órganos del Sistema Interamericano. ${ }^{6}$

Primeramente, es importante recordar que el carácter internacional de los derechos humanos permite una interpretación extensiva y evolutiva de los derechos tanto de la Declaración Americana de Derechos y Deberes del Hombre como de la Convención Americana sobre Derechos Humanos (en adelante "la Convención", "la Convención Americana" o "la CADH”). En ese sentido, los órganos del Sistema Interamericano han dado contenido específico a derechos no expresamente mencionados en

${ }^{5}$ Este capítulo corresponde, en gran parte, al artículo de Karla I. Quintana Osuna, "Algunas reflexiones sobre la evolución en el reconocimiento de los derechos de los pueblos indígenas y tribales en el sistema interamericano". En proceso de publicación.

${ }^{6}$ Citroni, Gabriela y Quintana Osuna, Karla, "Reparations for Indigenous Peoples in the Inter-American Court", en Reparations for Indigenous Peoples. International and Comparative Perspectives, Lenzerini, Federico (ed.), Oxford University Press, 2008, pp. 317-344. En virtud de las características específicas del presente escrito, la autora no pretende realizar un análisis exhaustivo de la totalidad de precedentes y temas abordados por el sistema. Tampoco pretende entrar en discusiones que, si bien son necesarias en el diálogo interjurisprudencial, así como en el relativo a las políticas y prácticas en la materia, se quedarán en el tintero para posteriores escritos. 
la citada Convención ${ }^{7}$ - con referencia expresa al convenio No. 169 de la OIT como parámetro de interpretación, no de aplicación-, como es el derecho a la propiedad comunitaria, el derecho a la consulta, el daño a la integridad cultural o al saneamiento en territorio indígena.

\section{RECONOCIMIENTO DE LA PROPIEDAD COMUNAL: OBLIGACIONES DE DELIMITAR, DEMARCAR, TITULAR, SANEAR Y CONSULTAR A LOS PUEBLOS INDÍGENAS Y TRIBALES}

Tanto la Comisión IDH como la Corte IDH han prestado especial atención al derecho de los pueblos indígenas y tribales, ${ }^{8}$ a la propiedad comunal sobre sus tierras como un derecho en sí mismo, y como garantía del disfrute efectivo de otros derechos. ${ }^{9}$ La Comisión IDH ha manifestado que "la protección del derecho

7 Esta práctica se ha realizado con base en la interpretación evolutiva de los derechos humanos. Cfr. Corte IDH, El Derecho a la Información sobre la Asistencia Consular en el Marco de las Garantías del Debido Proceso Legal. Opinión Consultiva OC-16/99 del 1 de octubre de 1999. Serie A, No. 16.

8 Un pueblo tribal es "un pueblo que no es indígena a la región [que habita] pero que comparte características similares con los pueblos indígenas, como tener tradiciones sociales, culturales y económicas diferentes de otras secciones de la comunidad nacional, identificarse con sus territorios ancestrales y estar regulados, al menos en forma parcial, por sus propias normas, costumbres o tradiciones". Corte IDH, Caso del Pueblo Saramaka vs. Surinam. Excepciones Preliminares. Fondo, Reparaciones y Costas. Sentencia del 28 de noviembre de 2007. Serie C, No. 172, párr. 79. Esta definición concuerda con lo establecido en el artículo 1.1 (a) del Convenio 169 de la OIT. Sin embargo, la Corte ha aplicado los estándares sobre protección de tierras ancestrales sin distinción alguna entre pueblos indígenas y tribales.

9 Comisión IDH, Informe sobre derechos de los Pueblos Indígenas y Tribales sobre sus tierras ancestrales y recursos naturales. Normas y jurisprudencia del Sistema Interamericano de Derechos Humanos (en adelante "Informe sobre derechos de los Pueblos Indígenas y Tribales sobre sus tierras ancestrales y recursos naturales"), 30 de diciembre de 2009, párr. 3. 
Este libro forma parte del acervo de la Biblioteca Jurídica Virtual del Instituto de Investigaciones Jurídicas de la UNAM

a la propiedad de los pueblos indígenas sobre sus territorios ancestrales es un asunto de especial importancia, porque su goce efectivo implica no sólo la protección de una unidad económica, sino la protección de los derechos humanos de una colectividad que basa su desarrollo económico, social y cultural en la relación con la tierra"10 Y la Corte IDH ha agregado que "la protección de la relación del territorio con los recursos naturales tradicionalmente usados, bajo el derecho a la propiedad comunitaria permitirá asegurar su subsistencia, respetando e integrando su propia "cosmovisión e identidad cultural y espiritual'". ${ }^{11}$

Si bien el artículo 21 de la Convención Americana reconoce el "Derecho a la Propiedad Privada", en los trabajos preparatorios de la Convención Americana se reemplazó “[t]oda persona tiene el derecho a la propiedad privada, pero la ley puede subordinar su uso y goce al interés público" por la de “[t]oda persona tiene derecho al uso y goce de sus bienes. La Ley puede subordinar tal uso y goce al interés social”. Es decir, se optó por hacer referencia al "uso y goce de los bienes" en lugar de "propiedad privada", ${ }^{12}$ lo que —como se verá- posteriormente permitió hacer la interpretación para tierras comunitarias y territorios.

10 Alegatos de la Comisión IDH ante la Corte IDH, en Corte IDH, Caso Comunidad Indígena Yakye Axa vs. Paraguay. Fondo Reparaciones y Costas. Sentencia del 17 de junio de 2005. Serie C, No. 125, párr. 120(c).

11 Corte IDH, Caso Pueblo Indígena Kichwa de Sarayaku vs. Ecuador. Fondo y Reparaciones. Sentencia del 27 de junio de 2012. Serie C, No. 245, párr. 155.

12 En el estudio y consideración de los trabajos preparatorios de la Convención Americana sobre Derechos Humanos, el derecho a la propiedad privada fue uno de los más extensamente debatidos en el seno de la Comisión. Desde el primer momento las delegaciones manifestaron la existencia de tres corrientes ideológicas, a saber: una tendencia a suprimir del texto del proyecto toda referencia al derecho de propiedad; otra tendencia a consagrar el texto del proyecto tal y como fue presentado, y una tercera posición conciliadora que reforzaría la función social de la propiedad. Finalmente prevaleció el criterio de incorporar el derecho de propiedad en el texto de la Convención. Corte IDH, 
El concepto "bienes" fue definido por la Corte Interamericana en el Caso Ivcher Bronstein vs. Perú, en el que el tribunal determinó que “[I]os 'bienes' pueden ser conceptualizados como aquellas cosas materiales apropiables, así como todo derecho que pueda formar parte del patrimonio de una persona; dicho concepto comprende todos los muebles e inmuebles, los elementos corporales e incorporales y cualquier otro objeto inmaterial susceptible de valor". ${ }^{13}$

Así, si bien tradicionalmente el derecho a la propiedad ha sido considerado en su forma individual, cuando la Corte IDH conoció del Caso Mayagna (Sumo) Awas Tingni vs. Nicaragua, determinó el alcance comunitario del derecho a la propiedad territorial ${ }^{14}$ al estipular que:

[l]os términos de un tratado internacional de derechos humanos tienen sentido autónomo, por lo que no pueden ser equiparados al sentido que se les atribuye en el derecho interno. Además, dichos tratados de derechos humanos son instrumentos vivos cuya interpretación tiene que adecuarse a la evolución de los tiempos y, en particular, a las condiciones de vida actuales. ${ }^{15}$

Caso de la Comunidad Mayagna (Sumo) Awas Tingni vs. Nicaragua. Fondo, Reparaciones y Costas. Sentencia del 31 de agosto de 2001. Serie C, No. 79, párrs. 143 y 145.

13 Corte IDH, Caso Ivcher Bronstein vs. Perú, Fondo, Reparaciones y Costas. Sentencia del 6 de febrero del 2001, Serie C, No. 74, párr. 122. En el mismo sentido: Caso Comunidad indígena Yakye Axa vs. Paraguay, Fondo, Reparaciones y Costas. Sentencia del 17 de junio de 2005. Serie C, No. 125, párr. 137; Caso de la Comunidad Mayagna (Sumo) Awas Tingni vs. Nicaragua, Fondo, Reparaciones y Costas. Sentencia del 31 de agosto de 2001. Serie C, No. 79, párr. 144.

${ }^{14}$ González Morales, Felipe, Sistema Interamericano de Derechos Humanos, Valencia, Tirant lo Blanch-Tratados, 2013, p. 432.

${ }_{15}$ Corte IDH, Caso de la Comunidad Mayagna (Sumo) Awas Tingni vs. Nicaragua, Fondo, Reparaciones y Costas. Sentencia del 31 de agosto de 2001. Serie C, No. 79, párr. 146. En el mismo sentido: Corte IDH, El Derecho a la In- 
Este libro forma parte del acervo de la Biblioteca Jurídica Virtual del Instituto de Investigaciones Jurídicas de la UNAM

La Corte IDH se refirió al artículo 29.b) de la Convención Americana que señala que "ninguna disposición de la misma, podrá ser interpretada de manera que se limite el goce y ejercicio de otro derecho o libertad que pudiera estar reconocido por otra Convención en la que el Estado sea parte". Y, citando a la Corte Internacional de Justicia resaltó "la importancia de tomar en cuenta el sistema jurídico en el cual se inscriben y el momento en que la interpretación tiene lugar". ${ }^{16}$ De lo anterior concluyó que, con base en esa interpretación evolutiva, "el artículo 21 de la Convención protege el derecho a la propiedad en un sentido que comprende, entre otros, los derechos de los miembros de las comunidades indígenas en el marco de la propiedad comunal". ${ }^{17}$

La Corte, además, ha analizado el derecho de propiedad del territorio de los pueblos indígenas en conjunto con otros instrumentos internacionales, como el Convenio 169 de la OIT, el Pacto Internacional de Derechos Civiles y Políticos y el Pacto Internacional de Derechos Económicos, Sociales y Culturales. En este sentido, la Corte ha afirmado que, al dar interpretación a un tratado, no sólo se toman en cuenta los acuerdos e instrumentos formalmente relacionados con éste (inciso segundo del artículo 31 de la Convención de Viena), sino también el sistema dentro del cual se inscribe (inciso tercero del

formación sobre la Asistencia Consular en el Marco de las Garantías del Debido Proceso Legal. Opinión Consultiva OC-16/99 del 1 de octubre de 1999. Serie A, No. 16, párr. 114, citando: CEDH, Tyrer vs. The United Kingdom, 5856/72. Sentencia del 25 de abril de 1978. Series A, No. A26, párr. 31.

${ }^{16}$ Corte IDH, El Derecho a la Información sobre la Asistencia Consular en el Marco de las Garantías del Debido Proceso Legal. Opinión Consultiva OC16/99 del 1 de octubre de 1999. Serie A No. 16, párr. 113.

17 Corte IDH, Caso Mayagna (Sumo) Awas Tingni vs. Nicaragua. Fondo, Reparaciones y Costas. Sentencia del 31 de agosto del 2001. Serie C, No. 79, párr. 148. 
mismo artículo). ${ }^{18}$ De igual manera, el Tribunal Interamericano ha considerado que podría "abordar la interpretación de un tratado siempre que esté directamente implicada la protección de los derechos humanos en un Estado miembro del Sistema Interamericano", ${ }^{19}$ aunque dicho instrumento no provenga del mismo sistema regional de protección. ${ }^{20}$ De esta manera, la protección colectiva de los derechos territoriales de los pueblos indígenas en el Sistema Interamericano encuentra su protección en el artículo 21, pero también ampliando su interpretación a la luz de otros instrumentos internacionales de derechos humanos.

\section{A. Obligación de delimitación, demarcación y titulación}

El primer caso ante la Corte IDH en relación con la propiedad comunitaria indígena es el de la Comunidad Mayagna (Sumo) Awas Tingni vs. Nicaragua, del 31 de agosto de 2001, en el cual se determinó que el derecho a disfrutar del derecho a la

18 Corte IDH, Caso Tibi vs. Ecuador, Excepciones Preliminares, Fondo, Reparaciones y Costas. Sentencia del 7 de septiembre de 2004. Serie C, No. 114, párr. 144. En igual sentido, Convención de Viena sobre el derecho de los Tratados.

19 Corte IDH, "Otros Tratados" Objeto de la Función Consultiva de la Corte (art. 64 Convención Americana sobre Derechos Humanos). Opinión Consultiva OC-1/82 del 24 de septiembre del 1982. Serie A, No. 1, párr. 21.

20 Además, "[n]o existe ninguna razón para excluir, previa y abstractamente, que pueda solicitarse de la Corte, y ésta emitir, una consulta sobre un tratado aplicable a un Estado americano en materia concerniente a la protección de los derechos humanos, por el solo hecho de que sean también partes de dicho tratado, Estados que no pertenecen al sistema interamericano, o de que no haya sido adoptado dentro del marco o bajo los auspicios de éste". En Corte IDH, "Otros Tratados" Objeto de la Función Consultiva de la Corte (art. 64 Convención Americana sobre Derechos Humanos). Opinión Consultiva OC-1/82 del 24 de septiembre de 1982. Serie A No. 1, párr. 48, y Condición Jurídica y Derechos Humanos del Niño. Opinión Consultiva OC-17/02 del 28 de agosto de 2002. Serie A, No. 17, párr. 22. 
propiedad, protegido en el artículo 21 de la Convención Americana, incluye el derecho de los pueblos indígenas para la protección de su propiedad comunal. ${ }^{21}$ En ese sentido, la Corte destacó que:

Entre los indígenas existe una tradición comunitaria sobre una forma comunal de la propiedad colectiva de la tierra, en el sentido de que la pertenencia de ésta no se centra en un individuo sino en el grupo y su comunidad. Los indígenas por el hecho de su propia existencia tienen derecho a vivir libremente en sus propios territorios; la estrecha relación que los indígenas mantienen con la tierra debe de ser reconocida y comprendida como la base fundamental de sus culturas, su vida espiritual, su integridad y su supervivencia económica. Para las comunidades indígenas la relación con la tierra no es meramente una cuestión de posesión y producción sino un elemento material y espiritual del que deben gozar plenamente, inclusive para preservar su legado cultural y transmitirlo a las generaciones futuras. ${ }^{22}$

En dicho caso, el Estado había faltado a su deber de delimitar y demarcar el territorio de la Comunidad Awas Tingni, respecto del cual otras comunidades, y el propio Estado, consideraban que existían traslapes, e incluso, Nicaragua había otorgado concesiones de manejo forestal y tala a terceras personas. La situación había creado "un clima de incertidumbre permanente entre los miembros de la Comunidad... en cuanto no sab[ían]

21 Anaya, James y Grossman, Claudio, "The Case of Awas Tingni vs. Nicaragua: A New Step in the International Law of Indigenous Peoples", Arizona Journal of International and Comparative Law, vol. 19, núm. 1, 2002, pp. 1-15.

22 Corte IDH, Caso Mayagna (Sumo) Awas Tingni vs. Nicaragua. Fondo, Reparaciones y Costas. Sentencia del 31 de agosto del 2001, Serie C, No. 79, párr. 149. 
con certeza hasta dónde se ext[endía] geográficamente su derecho de propiedad comunal y, consecuentemente, desconoc[ían] hasta dónde $\mathrm{p}$ [odía]n usar y gozar libremente de los respectivos bienes". ${ }^{23}$

Por tal motivo, la Corte, en su sentencia, determinó que el modo de subsistencia, así como el uso y goce de la tierra habitada por la comunidad, eran "llevadas a cabo dentro de un espacio territorial de acuerdo con un esquema de organización colectiva tradicional", ${ }^{24}$ y ordenó a Nicaragua delimitar, demarcar y titular el territorio de la comunidad, además de abstenerse de realizar "hasta tanto no se reali[zara] esa delimitación, demarcación y titulación, actos que pu[dier]an llevar a que los agentes del propio Estado, o terceros que actúen con su aquiescencia o su tolerancia, afecten la existencia, el valor, el uso o el goce de los bienes ubicados en la zona geográfica donde habitan y realizan sus actividades los miembros de la Comunidad". ${ }^{25}$ En 2009 la Corte IDH dio por cumplida la sentencia, constituyendo una de las pocas con cumplimiento total en la jurisprudencia del Tribunal. ${ }^{26}$

Después de la sentencia de Mayagna (Sumo) Awas Tingni, existen tres sentencias importantes de la Corte IDH -a las que deben agregarse dos casos más conocidos exclusivamente por la Comisión IDH- en cuanto al reconocimiento efectivo de los derechos de los pueblos indígenas a sus territorios ancestrales. Nos referiremos a estos casos como los casos paraguayos: Caso Comunidad Indígena Yakye Axa vs. Paraguay, del 17 de

${ }^{23}$ Corte IDH, Caso Mayagna (Sumo) Awas Tingni vs. Nicaragua. Fondo, Reparaciones y Costas. Sentencia del 31 de agosto del 2001, Serie C, No. 79, párr. 153.

24 Ibidem, párr. 103e).

25 Ibidem, párr. 153.

26 Corte IDH, Resolución de Supervisión de Cumplimiento de Sentencia, Caso de la Comunidad Mayagna (Sumo) Awas Tingni, 3 de abril de 2009. 
Este libro forma parte del acervo de la Biblioteca Jurídica Virtual del Instituto de Investigaciones Jurídicas de la UNAM

junio de 2005; Caso Comunidad Indígena Sawhoyamaxa vs. Paraguay, del 29 de marzo de 2006, y Caso Comunidad Indígena Xákmok Kásek vs. Paraguay, del 24 de agosto de 2010.27

En las sentencias de los Casos de las Comunidades Indígenas de Yakye Axa y Sawhoyamaxa, ambos contra Paraguay, la Corte IDH hizo un análisis histórico, llegando a la conclusión de que dichas comunidades habían habitado ancestralmente ciertos territorios del Chaco paraguayo, por lo que el Estado estaba obligado a devolvérselos, pese a que los mismos estuvieran a nombre de propietarios particulares y aun cuando estuvieran siendo explotados. En ese sentido, la Corte especificó claramente que el hecho de que las tierras ancestrales de las comunidades estuvieran siendo productivas para los actuales propietarios no era razón para no devolverlas. No obstante, la Corte previó en sus sentencias la posibilidad de que, en caso de que no fuera posible, por razones justificadas, reintegrarlas, el Estado podía devolver tierras alternativas, siguiendo las propias formas de consulta y decisión de las comunidades, sus valores, usos y costumbres. ${ }^{28}$ La Corte otorgó al Estado paraguayo plazos

27 Véase, además, demanda de la Comisión IDH (2005), Comunidad Indígena de Sawhoyamaxa, 2 de febrero de 2005, y la demanda de la Comisión IDH (2009), Comunidad Indígena Xákmok Kásek, 3 de julio de 2009, en http:// www.oas.org/es/cidh/decisiones/demandas.asp. Véase también el Informe de Admisibilidad núm. 55/07, 24 de julio de 2007, en el Caso Comunidad Indígena Kelyenmagategma del Pueblo Enxet-Lengua y sus miembros vs. Paraguay. Así como el Informe No. 90/99, Caso 11.713, 29 de septiembre de 1999, en el Caso de las Comunidades Indígenas Enxet-Lamenxay y Kayleyphapoyet (Riachito) vs. Paraguay.

${ }^{28}$ Véase en este sentido: "Si por motivos objetivos y fundamentados, la reivindicación del territorio ancestral de los miembros de la Comunidad Yakye Axa no fuera posible, el Estado deberá entregarle tierras alternativas, que serán electas de modo consensuado con la Comunidad, conforme a sus propias formas de consulta y decisión, valores, usos y costumbres. En uno u otro caso, la extensión de las tierras deberá ser la suficiente para garantizar el mantenimiento y desarrollo de la propia forma de vida de la Comunidad". Corte IDH, 
de tres años (contados a partir de la notificación de las sentencias) para cumplir con esa obligación.

Tres años después de la sentencia de la comunidad indígena de Sawhoyamaxa, ${ }^{29}$ la Corte volvió a conocer un caso similar, el de la comunidad indígena de Xákmok Káse ${ }^{30}{ }^{30}$ en cuya sentencia reiteró los estándares previamente establecidos, con un importante cambio. En una decisión sin precedentes jurisprudenciales en la Corte IDH, ésta ordenó nuevamente a Paraguay reconocer, devolver y titular los territorios ancestrales, pero determinó que, de no cumplirse la orden en el tiempo previsto de tres años, el Estado tendría que pagar diez mil dólares por cada mes de retraso. ${ }^{31}$ Decisión que sólo puede leerse, estimamos, a la luz del incumplimiento total por parte del Estado paraguayo, hasta ese momento, de las sentencias en los Casos de las comunidades Yakye Axa y Sawhoyamaxa en cuanto a la devolución de su territorio.

Es importante destacar que, en cumplimiento de la sentencia de la Corte IDH, Paraguay tituló, a principios de 2012, tierras alternativas a la comunidad de Yakye $A x a,{ }^{32}$ las cuales, sin

Caso Comunidad Indígena Yakye Axa vs. Paraguay, Fondo, Reparaciones y Costas. Sentencia del 17 de junio de 2005. Serie C, No. 125, párr. 217.

${ }^{29}$ Es importante destacar el cambio conceptual de la Corte en el caso de la Comunidad de Sawhoyamaxa comparado con Yakye Axa en el acápite de reparaciones. En el caso de Yakye Axa la Corte ordenó la devolución del territorio dentro del concepto de otras formas de reparación, y en el caso de Sawhoyamaxa lo hace al inicio del capítulo de reparaciones, en el entendido que sería una forma cercana a la restitutio in integrum.

30 Comisión IDH, demanda del 3 de julio de 2009, en http://www.cidh.org/ demandas/12.420\%20Xakmok\%20Kasek\%20Paraguay\%203jul09\%20ESP. pdf.

${ }^{31}$ Corte IDH, Caso Comunidad Indígena Xákmok Kásek vs. Paraguay, Fondo, Reparaciones y Costas. Sentencia del 24 de agosto de 2010. Serie C, No. 214, párr. 288.

32 “El Paraguay devolvió a Yakye Axa su tierra”, en http://www.tierraviva.org. py/site/noticias_int/22. 
embargo, no se encuentran bien comunicadas, por lo que actualmente se está intentando, por la vía judicial y legislativa, crear una servidumbre de paso o un camino público que llegue hasta las tierras. Con relación a las tierras de la comunidad de Sawhoyamaxa, el 30 de septiembre de 2014, la Sala Constitucional de la Corte Suprema de Justicia, mediante la Sentencia No. 981, declaró de interés social la expropiación - a favor del Instituto Nacional del Indígena (INDI)— de más de 14 mil hectáreas para su posterior transferencia a la comunidad, para así restituir parte de su territorio tradicional. No obstante, es preocupante la información relativa a la existencia una nueva acción de inconstitucionalidad relativa a la expropiación de las tierras. ${ }^{33}$

Si bien las acciones anteriores comparten un importante paso en el reconocimiento del derecho de los pueblos indígenas, queda sin respuesta la orden de la Corte IDH de que el Estado diera razones justificadas para no otorgar a las comunidades sus territorios ancestrales. Tal como se resaltó por la delegación paraguaya en audiencia pública sobre la supervisión del cumplimiento de este punto ante la Corte IDH, ${ }^{34}$ luego de diversos intentos del Poder Ejecutivo por expropiar las tierras, las propuestas fueron frenadas por el Poder Legislativo con el argumento de que las tierras estarían siendo productivas —argumento inválido desde lo destacado en las propias sentencias de la Corte IDH_- Ante el poco éxito, el Poder Ejecutivo, a través del INDI, intentó en varias ocasiones comprar las tierras, pero en algunos casos obtuvieron como respuesta el aumento exorbitante de precios por parte de los dueños actuales, por lo

33 Nota de prensa de la Corte Suprema de Justicia de Paraguay, Realizan aclaración sobre sentencias, 24 de febrero de 2015, en http://www.pj.gov.py/ notas/10638-realizan-aclaracion-sobre-sentencias.

34 Véase video de audiencia pública, compuesta de supervisión de cumplimiento al respecto, en noviembre de 2011, en http://vimeo.com/32480699. 
que se optó por la entrega de tierras alternativas, con el acuerdo de la comunidad.

Con relación al tercer caso, el de la comunidad de Xákmok Kásek, existe información pública de que en marzo de 2015 autoridades paraguayas se reunieron con miembros de la comunidad para informarles sobre los trámites administrativos llevados a cabo para adquirir las tierras que aquélla reivindica, sin que existan avances concretos. ${ }^{35}$ Además, no se sabe a ciencia cierta si el gobierno está pagando la cantidad ordenada por la Corte IDH en caso de que no restituyera las tierras a la comunidad en el plazo de tres años luego de la emisión de la sentencia, plazo que ya venció.

Ahora bien, es importante destacar que meses antes de que Paraguay devolviera las tierras a la comunidad indígena de Yakye Axa, hizo lo propio con un cuarto caso, el de la comunidad de Kelyenmagategma, en trámite ante la Comisión IDH y respecto del cual existe un informe de admisibilidad. ${ }^{36}$ Asimismo, más de ocho años antes, Paraguay había llegado a un pacto de solución amistosa en el que se concertó, entre otros acuerdos, la devolución de las tierras a las comunidades indígenas Enxet-Lamenxay y Kayleyphapopyet. ${ }^{37}$

En cuanto a las similitudes de los tres casos, la Corte IDH consolidó una serie de reglas respecto a la propiedad comunitaria indígena:

35 Véase http://www.tierraviva.org.py.

$36 \mathrm{CIDH}$, Informe de Admisibilidad No. 55/07, Petición 987-04, Comunidad Indígena Kelyenmagategma del Pueblo Enxet-Lengua y sus miembros, respecto de Paraguay, 24 de julio de 2007.

$37 \mathrm{CIDH}$, Informe de Solución Amistosa No. 90/99, Caso 11.713, Comunidades Indígenas Enxet-Lamenxay y Kayleyphapopyet-Riachito, respecto de Paraguay, 29 de septiembre de 1999. 
El Tribunal recuerda su jurisprudencia respecto a la propiedad comunitaria de las tierras indígenas, según la cual: 1) la posesión tradicional de los indígenas sobre sus tierras tiene efectos equivalentes al título de pleno dominio que otorga el Estado; 2) la posesión tradicional otorga a los indígenas el derecho a exigir el reconocimiento oficial de propiedad y su registro; 3) el Estado debe delimitar, demarcar y otorgar título colectivo de las tierras a los miembros de las comunidades indígenas; 4) los miembros de los pueblos indígenas que por causas ajenas a su voluntad han salido o perdido la posesión de sus tierras tradicionales mantienen el derecho de propiedad sobre las mismas, aún a falta de título legal, salvo cuando las tierras hayan sido legítimamente trasladadas a terceros de buena fe, y 5) los miembros de los pueblos indígenas que involuntariamente han perdido la posesión de sus tierras, y éstas han sido trasladadas legítimamente a terceros inocentes, tienen el derecho de recuperarlas o a obtener otras tierras de igual extensión y calidad. ${ }^{38}$

Adicionalmente, la Corte IDH identificó que Paraguay reconocía el derecho de los pueblos indígenas a solicitar la devolución de sus tierras tradicionales perdidas, inclusive cuando se encontraran bajo dominio privado y no tuvieran plena posesión de las mismas. El Estatuto de Comunidades Indígenas paraguayo contemplaba el procedimiento a seguirse para la reivindicación de tierras bajo dominio privado, por lo que si bien los miembros de las comunidades no tenían la posesión de las tierras reclamadas, conforme a la jurisprudencia de la Corte y al derecho interno paraguayo, tenían el derecho de recuperarlas. ${ }^{39}$

38 Corte IDH, Caso Comunidad Indígena Xákmok Kásek vs. Paraguay, Fondo, Reparaciones y Costas. Sentencia del 24 de agosto de 2010. Serie C, No. 214, párr. 109.

39 Ibidem, párrs. 110 y 111. 
Hasta este punto jurisprudencial, la Corte IDH había desarrollado tres obligaciones: demarcar, delimitar y titular. Sin embargo, ni la Corte IDH ni la Comisión IDH han establecido la diferencia entre las obligaciones de delimitar y demarcar, pues la jurisprudencia interamericana pareciera usarlas indistintamente.

En 2013, la Comisión IDH presentó ante la Corte IDH el Caso de los Pueblos Indígenas Kuna de Madungandí y Emberá de Bayano y sus miembros vs. Panamá, en el que se alegaba la violación continuada del derecho a la propiedad colectiva de dichos pueblos, como consecuencia del incumplimiento por parte de Panamá, del pago de indemnizaciones económicas derivadas del despojo e inundación de sus territorios ancestrales desde el año 1969. En el caso se planteó también la falta de reconocimiento, titulación y demarcación, durante mucho tiempo, de las tierras otorgadas al pueblo indígena Kuna de Madungandí, y la falta de reconocimiento, demarcación y titulación, de las tierras otorgadas al pueblo indígena Emberá de Bayano. Además, la Comisión IDH planteó la falta de protección efectiva del territorio y los recursos naturales, y destacó que el Estado incumplió con sus obligaciones de prevención frente a la invasión de colonos no indígenas y la tala ilegal de madera. Finalmente, la Comisión alegó el incumplimiento estatal para brindar, de manera pronta y efectiva, acceso a los pueblos indígenas a la propiedad de sus territorios. ${ }^{40}$

La sentencia de la Corte IDH resultó poco afortunada, tanto para el caso en concreto como por los criterios que omitió desarrollar para los pueblos indígenas y tribales de la región. En efecto, el desarrollo jurisprudencial de la Corte poco respondió

$40 \mathrm{CIDH}$, Informe de Fondo No. 125/12, Caso 12.354, Pueblos Indígenas Kuna de Madungandí y Emberá de Bayano y sus miembros respecto de Panamá, 26 de febrero de 2013, en http://www.oas.org/es/cidh/decisiones/ corte/12.354FondoEsp.pdf. 
Este libro forma parte del acervo de la Biblioteca Jurídica Virtual del Instituto de Investigaciones Jurídicas de la UNAM

a los alegatos planteados sobre la violación al derecho a la propiedad.

Por otra parte, es cuestionable la posición de la Corte IDH en la excepción preliminar en razón de tiempo (ratione temporis) para dejar fuera de la litis del caso la violación continuada por la falta del pago de la indemnización pactada, ${ }^{41}$ pues la Corte IDH decidió, en el fondo, la violación del artículo 21 de la Convención Americana por la ausencia de delimitación, demarcación y titulación de las tierras de las comunidades afectadas; y dejó fuera de su análisis - en excepciones preliminares - la indemnización que el Estado se había comprometido a otorgar. La Corte IDH justificó dicha diferencia en que la obligación de delimitación, demarcación y titulación de las tierras es a partir de la aceptación de la competencia contenciosa del tribunal por parte del Estado y no antes, como habría sucedido con el tema de la falta del pago de la indemnización. No obstante, la crítica se dirige hacia la omisión, por parte de la Corte IDH, de brindar mayor fundamentación y motivación a su razonamiento en cuanto a que la falta de indemnización, la cual tiene una afectación colateral a otros derechos - y a lo largo del tiempo- no implicara, en el caso concreto, una violación continuada.

La Corte IDH mucho pudo aportar para establecer obligaciones específicas de una justa indemnización para los pueblos indígenas de la región una vez que éstos han sido afectados en su territorio, específicamente cuando ya se han concretado los proyectos de desarrollo (independientemente de si se respetó o no el derecho a la consulta previa). En todo caso, se perdió una oportunidad para desarrollar su jurisprudencia en una problemática a la cual se enfrentan los pueblos indígenas cons-

41 Corte IDH, Caso de los Pueblos Indígenas Kuna de Madungandí y Emberá de Bayano y sus miembros vs. Panamá, Excepciones Preliminares, Fondo, Reparaciones y Costas. Sentencia del 14 de octubre de 2014. Serie C, No. 284. 
tantemente, ya que en muchos casos las transgreciones tienen naturaleza de violaciones continuadas compuestas. ${ }^{42}$

Aunado a lo anterior, la Corte IDH optó por una postura muy similar al Caso Mayagna (Sumo) Awas Tingni vs. Nicaragua, resuelto trece años antes -y reiterado por los casos paraguayos-, al establecer que el Estado había fallado en su obligación de delimitar, demarcar y titular las tierras a las cuales habían sido desplazados los pueblos luego de que fueran despojados de sus territorios ancestrales, sin distinguir entre las tres acciones, lo que, en el presente caso, hubiera sido de gran utilidad no sólo para reparar la violación al derecho a la propiedad comunal, sino para resolver, de hecho, el problema actual que viven esos pueblos. Asimismo, hubiera brindado una herramienta importante al dar contenido y alcance a dicho derecho en un tema que es constante con las tierras de los pueblos indígenas. Tampoco abordó la Corte IDH, de manera directa, el planteamiento sobre la obligación del Estado respecto de terceros, invasores no indígenas, a los territorios de los pueblos indígenas, como sucedió en el presente caso.

Bajo este panorama, es claro que la Corte IDH omitió desarrollar importantes y nuevos temas directamente planteados, teniendo como consecuencia el no dar contenido a las obligaciones de los Estados parte de la Convención Americana frente a los pueblos indígenas.

\section{B. Obligación de saneamiento}

La Comunidad Garífuna de Punta Piedra y sus miembros tenían el territorio titulado a su favor, pero sus miembros no po-

42 Voto del Juez Eduardo Ferrer Mac-Gregor al caso Corte IDH, Caso de los Pueblos Indígenas Kuna de Madungandí y Emberá de Bayano y sus miembros vs. Panamá, Excepciones Preliminares, Fondo, Reparaciones y Costas. Sentencia del 14 de octubre de 2014. Serie C, No. 284, párr. 35. 
Este libro forma parte del acervo de la Biblioteca Jurídica Virtual del Instituto de Investigaciones Jurídicas de la UNAM

dían ingresar a él pues se encontraba en un poblado con infraestructura; es decir, no tenían acceso real al territorio. ${ }^{43}$ Así que en este caso, la Corte IDH reiteró la obligación del Estado de garantizar el uso y goce efectivo del derecho a la propiedad indígena o tribal, para lo cual debían adoptarse diversas medidas, "entre ellas el saneamiento de la tierra", el cual "consiste en un proceso que deriva en la obligación del Estado de remover cualquier tipo de interferencia sobre el territorio en cuestión", ${ }^{44}$ incluidos los terceros sin título de dominio.

\section{Derecho/obligación de consulta}

Dentro del análisis del derecho a la propiedad de los pueblos indígenas, la Comisión IDH ha realizado una interpretación evolutiva dando especial importancia al derecho de consulta que tienen los pueblos indígenas y tribales a través de pronunciamientos en casos específicos, ${ }^{45}$ así como en informes de país ${ }^{46}$

43 Corte IDH, Caso Comunidad Garífuna de Punta Piedra y sus miembros vs. Honduras, Excepciones Preliminares, Fondo, Reparaciones y Costas. Sentencia del 8 de octubre de 2015. Serie C, No. 304, párr. 170.

44 Ibidem, párr. 181.

$45 \mathrm{CIDH}$, Informe de Fondo No. 40/04, Caso 12.053, Comunidades Indígenas Mayas del Distrito de Toledo vs. Belice, 12 de octubre de 2004; CIDH, Informe de Fondo No. 75/02, Caso 11.140, Mary y Carrie Dann vs. Estados Unidos, 27 de diciembre de 2002. Véase $\mathrm{CIDH}$, Demanda ante la Corte IDH en el Caso de los doce Clanes Saramaka (Caso 13.338) vs. la República de Suriname, 23 de junio de 2006, y la Demanda ante la Corte IDH en el caso del Pueblo Indígena Kichwa de Sarayaku y sus miembros (Caso 12.465) vs. Ecuador, 26 de abril de 2010, en http://www.oas.org/es/cidh/decisiones/demandas.asp.

46 Véase, por ejemplo, CIDH, Informe de Seguimiento, Acceso a la justicia e inclusión social: El camino hacia el fortalecimiento de la democracia en Bolivia, OEA/Ser/L/V/II.135, Doc. 40, 7 de agosto de 2009; CIDH, Informe sobre la situación de los derechos humanos en Ecuador, Conclusiones del Capítulo IX, OEA/Ser.L/II.96, Doc. 10, rev. 1, 24 de abril de 1997; CIDH, Tercer Informe sobre la situación de los derechos humanos en Colombia, Capítulo X, Recomendación No. 4, OEA/Ser.L/V/II.102, Doc. 9 rev. 1, 26 de febrero de 
e informes temáticos. ${ }^{47}$ En virtud de las características del presente escrito nos enfocaremos únicamente en los casos.

La Comisión IDH, en decisiones precursoras en el tema de consulta previa, se pronunció en los Casos de las Comunidades Indígenas Mayas del Distrito de Toledo vs. Belice y en el de las Hermanas Mary y Carrie Dann vs. Estados Unidos. ${ }^{48}$

Con relación a este último caso, la Comisión IDH analizó la actividad aurífera llevada a cabo con la anuencia estatal en el territorio ancestral del pueblo Western Shoshone, sin consultarlos previamente. Al respecto, la Comisión IDH consideró que, respecto de dicha actividad, los miembros deberían "como mínimo [estar] plena y cabalmente informados de la naturaleza y las consecuencias del proceso y se les brinde una oportunidad efectiva de participar individual o colectivamente". ${ }^{49}$

Posteriormente, en el Caso de las Comunidades Indígenas Mayas del Distrito de Toledo vs. Belice, la Comisión IDH se refirió, entre otras, a una concesión maderera otorgada por el Estado. La Comisión IDH llegó a la conclusión de que:

[E]l Estado, al otorgar concesiones... a terceros para utilizar los bienes y recursos que podrían estar comprendidos por las tierras que deben ser delimitadas, demarcadas y tituladas 0 aclaradas y protegidas... sin consulta efectiva y sin el con-

1999; CIDH, Informe sobre acceso a la justicia e inclusión social: El camino hacia el fortalecimiento de la democracia en Bolivia, Capítulo IV, Derechos de los pueblos indígenas y comunidades campesinas, OEA/Ser.L/N/II, Doc. 34, 28 de junio de 2007.

$47 \mathrm{CIDH}$, Informe sobre derechos de los Pueblos Indígenas y Tribales sobre sus tierras ancestrales y recursos naturales, OEA/Ser.L/V/II., Doc. 56/09, 30 de diciembre de 2009.

48 Ninguno de los anteriores casos fue conocido por la Corte IDH, en virtud de que ni Estados Unidos ni Belice han aceptado su competencia.

$49 \mathrm{CIDH}$, Informe de Fondo No. 75/02, Caso 11.140, Mary y Carrie Dann vs. Estados Unidos, 27 de diciembre de 2002, párr. 140. 
sentimiento informado del pueblo maya, y que dieron lugar a un perjuicio contra el medio ambiente, también viola el derecho de propiedad... en perjuicio del pueblo maya. [En ese sentido, resaltó que] uno de los elementos centrales para la protección de los derechos de propiedad de los indígenas, es el requisito de que los Estados establezcan consultas efectivas y previamente informadas con las comunidades indígenas en relación con los actos y decisiones que puedan afectar sus territorios tradicionales. ${ }^{50}$

En ese sentido, es importante destacar que en dicho caso, la Comisión IDH reconoció que los pueblos indígenas tienen, - desde el punto de vista del derecho internacional y los derechos humanos - derechos colectivos de propiedad sobre sus tierras tradicionales y sus recursos, independientemente de ser reconocidos a nivel nacional. ${ }^{51}$ Por tanto, concluyó que el Estado debía consultar a las comunidades mayas y obtener su consentimiento informado antes de tomar cualquier decisión que afectara sus tierras.

Posteriormente, la Comisión IDH sometió a la Corte IDH el Caso de los Doce Clanes Saramaka vs. Surinam. En su sentencia, la Corte IDH se pronunció, por primera vez, sobre el derecho de consulta de los pueblos indígenas y tribales, enmarcándolo dentro del derecho a la propiedad, consagrado en la Convención Americana en el artículo 21, y haciendo una interpretación evolutiva del mismo. En dicho caso, la Corte IDH consideró que Surinam estaba obligado a realizar la consulta, aun cuando éste no hubiera ratificado el Convenio 169 de la

$50 \mathrm{CIDH}$, Informe de Fondo No. 40/04, Caso 12.053, Comunidades Indígenas Mayas del Distrito de Toledo vs. Belice, 12 de octubre de 2004, párrs. 142 y 153 (citado en la demanda del Pueblo Kichwa de Sarayaku). Belice ratificó el Convenio OIT No. 169 en 1991.

51 Idem. 
OIT, puesto que consideró que la obligación surgía tanto de la Convención Americana como de otros instrumentos internacionales ratificados por el Estado, como el Pacto Internacional de Derechos Civiles y Políticos o el Pacto Internacional de Derechos Económicos, Sociales y Culturales. ${ }^{52}$

La Corte IDH destacó que los Estados deben garantizar la participación efectiva de los pueblos indígenas, conforme a sus costumbres y tradiciones, y previo consentimiento libre e informado con relación a "todo plan de desarrollo, inversión, exploración o extracción... que se lleve a cabo dentro de [su] territorio". ${ }^{53}$ Así, consideró que si el Estado quería restringir:

...legítimamente los derechos a la propiedad comunal, [el Estado debía] consultar con las comunidades afectadas respecto de los proyectos de desarrollo que se lleven a cabo en los territorios ocupados tradicionalmente, compartir los beneficios razonables con ellas, y realizar evaluaciones previas de impacto ambiental y social. ${ }^{54}$

Es necesario leer la sentencia de fondo del caso, junto con la sentencia de interpretación, en la cual la Corte precisó varios puntos, como el hecho de que la participación efectiva debe ser promovida por el Estado para llegar a un acuerdo:

52 Cabe destacar la reciente aprobación de la Declaración Americana sobre Derechos de los Pueblos Indígenas, aprobada el 14 de junio de 2016.

53 Corte IDH, Caso del Pueblo Saramaka vs. Surinam, Excepciones Preliminares, Fondo, Reparaciones y Costas. Sentencia del 28 de noviembre de 2007. Serie C, No. 172, párr. 129. El pueblo Saramaka, como parte de los distintos pueblos afrodescendientes maroon de Surinam, fue considerado como pueblo tribal por la Corte, puesto que no eran indígenas a Surinam, pero mantenían una relación con sus tierras y estructuras culturales y políticas diferenciadas de manera similar a los pueblos indígenas.

54 Ibidem, párr. 143. 
...requiere que el Estado acepte y brinde información al respecto en un formato entendible y públicamente accesible. Además... cuando se trate de planes de desarrollo o de inversión a gran escala que podrían afectar la integridad de las tierras y recursos naturales del pueblo (indígena o tribal), el Estado tiene la obligación, no sólo de consultar(los), sino también de obtener su consentimiento libre, informado y previo, según sus costumbres y tradiciones. ${ }^{55}$

En 2010, la Comisión IDH sometió ante la Corte IDH la demanda en el Caso del Pueblo Indígena Kichwa de Sarayaku vs. Ecuador. En junio de 2012, la Corte IDH emitió la sentencia en el caso referido, respecto de la cual se pueden destacar dos temas fundamentales con relación al derecho de consulta: por un lado, el momento a partir del cual se considera que el Estado se encuentra obligado a la consulta, y por otro, el alcance del consentimiento necesario en el proceso de consulta.

Respecto del primer punto, la Corte IDH concluyó que "está claramente reconocida hoy en día la obligación de los Estados de realizar procesos de consulta especiales y diferenciados cuando se vayan a afectar determinados intereses de las comunidades y pueblos indígenas" ${ }^{56}$ y que la obligación de consultar es un "principio general de derecho internacional". ${ }^{57}$ Para llegar a dicha conclusión se refirió a la Convención Americana "en conjunto con otros derechos reconocidos por el Estado en sus leyes internas o en otras normas internacionales relevantes", 58

55 Corte IDH, Caso del Pueblo Saramaka vs. Surinam, Interpretación de la Sentencia de Excepciones Preliminares, Fondo, Reparaciones y Costas. Sentencia del 12 de agosto de 2008. Serie C, No. 185, párr. 17.

56 Corte IDH, Caso Pueblo Indígena Kichwa de Sarayaku vs. Ecuador. Fondo y Reparaciones. Sentencia del 27 de junio de 2012. Serie C, No. 245, párr. 160.

57 Ibidem, párr. 164.

58 Ibidem, párr. 171. 
a su propia jurisprudencia en el Caso Saramaka, e hizo un recuento del reconocimiento que algunas legislaciones nacionales de las Américas hacen respecto del derecho a la consulta.

No obstante, la Corte IDH mantuvo una postura distinta a la de Saramaka en cuanto al nacimiento de la obligación de consultar. Recordemos que en dicha sentencia la Corte había considerado que no era necesaria la ratificación del Convenio 169 de la OIT. En el Caso Sarayaku, por otro lado, la Corte IDH asumió una postura intermedia, destacando que si bien antes de la ratificación de dicho convenio "existía la obligación de garantizar al pueblo Sarayaku el derecho al goce efectivo de su propiedad conforme su tradición comunitaria, teniendo en cuenta las particularidades propias de su identidad indígena en su relación con el territorio... al menos" desde que Ecuador ratificó el citado Convenio se tendría la obligación internacional en relación con el derecho de consulta, y desde que se consagraron los derechos colectivos de los pueblos indígenas y afroecuatorianos en la Constitución Política del Ecuador de 1998. ${ }^{59}$ Queda abierta la pregunta, entonces, de cómo se lee este razonamiento de la Corte a la luz de sus propias afirmaciones de que "se encuentra claramente establecida el derecho de consulta" y que la obligación de consultar es "un principio general de derecho internacional". ${ }^{60}$

Por otro lado, la sentencia de Sarayaku es relevante en cuanto a que la Corte IDH es más explícita en los requisitos para garantizar el derecho de consulta de los pueblos indígenas o tribales. Algunos de los requerimientos son:

1. La obligación de consultar es responsabilidad del Estado, por lo que la planificación y realización del proceso de con-

59 Ibidem, párr. 172.

60 Ibidem, párrs. 164 y 165. 
sulta no puede delegarse en una empresa privada o en terceros, "mucho menos en la misma empresa interesada en la explotación de los recursos en el territorio de la comunidad sujeto de la consulta". ${ }^{61}$

2. Involucramiento en todas las fases de planeación y desarrollo del proyecto - y no sólo cuando surja la necesidad de obtener la aprobación de la comunidad-que pueda afectar el territorio sobre el cual se asienta un pueblo indígena o tribal u otros derechos esenciales para su supervivencia.

3. No debe haber coerción contra el pueblo por parte del Estado o de agentes o terceros que actúen con su autorización o aquiescencia, es decir, no debe haber intentos de desintegración de la cohesión social de las comunidades afectadas.

4. La consulta no es un mero trámite formal, sino que debe concebirse como "un verdadero instrumento de participación", "de buena fe", donde debe haber "confianza mutua" y "con miras a alcanzar un consenso entre las mismas". ${ }^{62}$

5. Los procesos de diálogo y búsqueda de acuerdos deben realizarse desde las primeras etapas de la elaboración o planificación de la medida propuesta.

6. El Estado tiene el deber de consultar, activamente y de manera informada, con las comunidades, según sus costumbres, tradiciones y métodos tradicionales de toma de decisiones.

7. El Estado debe supervisar los estudios de impacto ambiental, a la luz de su deber de garantizar la efectiva participa-

61 Ibidem, párr. 187.

62 Ibidem, párr. 186. 
ción del pueblo indígena en el proceso de otorgamiento de concesiones. ${ }^{63}$

8. Los pueblos deben tener conocimiento de los posibles beneficios y riesgos, para que puedan evaluar si aceptan el plan de desarrollo o inversión propuesto.

9. Cuando se trate de consulta previa a la adopción de una medida legislativa, los pueblos indígenas deberán ser consultados previamente en todas las fases del proceso de producción normativa, y dichas consultas no deben ser restringidas a propuestas.

10. Es deber del Estado - y no de los pueblos indígenas- demostrar efectivamente, en el caso concreto, que todas las dimensiones del derecho a la consulta previa fueron efectivamente garantizadas.

Finalmente, corresponde hacer un comentario respecto del consentimiento necesario en la consulta. Si bien es cierto que la Corte IDH ya se había referido en el Caso Saramaka a la necesidad de que los pueblos indígenas dieran su consentimiento en megaproyectos que afectaran sus territorios, en el Caso Sarayaku, parecería que la Corte evitó entrar en la discusión. No obstante, de una lectura integral de la sentencia se podría concluir que la Corte lo toma en consideración, pero abordándolo de una manera distinta que con su precedente.

Así, cuando la Corte recuerda que "la consulta debe tener en cuenta los métodos tradicionales del pueblo o comunidad para la toma de decisiones", ${ }^{64}$ hace referencia al párrafo de

63 Un avance importante de la sentencia es el grado de detalle en relación con las características relativas a como debe realizarse un estudio de impacto ambiental.

64 Corte IDH, Caso Pueblo Indígena Kichwa de Sarayaku vs. Ecuador. Fondo y reparaciones. Sentencia del 27 de junio de 2012. Serie C, No. 245, párr. 177. 
Saramaka, que textualmente destaca que "cuando se trate de planes de desarrollo o de inversión a gran escala que tendrían un mayor impacto dentro del territorio, el Estado tiene la obligación, no sólo de consultar a los Saramakas, sino también debe obtener el consentimiento libre, informado y previo de éstos, según sus costumbres y tradiciones". ${ }^{65}$ Aunado a ello, en la sentencia de Sarayaku, la Corte constantemente hace referencia a la necesidad de buscar y llegar a acuerdos, mantener el diálogo y llegar a consensos.

Con independencia de lo anterior, es importante destacar que la Comisión Interamericana —en 2009_ identificó tres circunstancias en las cuales el requisito del consentimiento se vuelve de carácter obligatorio: ${ }^{66}$

a) Los planes o proyectos de desarrollo o inversión que impliquen el desplazamiento de los pueblos o comunidades indígenas de sus territorios tradicionales, es decir, su reubicación permanente.

b) En los casos en que la ejecución de planes de inversión o desarrollo o de concesiones de explotación de los recursos naturales privaría a los pueblos indígenas de la capacidad de gozar y usar sus tierras y otros recursos naturales necesarios para su subsistencia.

c) En el depósito o almacenamiento de materiales peligrosos en tierras o territorios indígenas.

65 Corte IDH, Caso del Pueblo Saramaka vs. Surinam. Excepciones Preliminares, Fondo, Reparaciones y Costas. Sentencia del 28 de noviembre de 2007. Serie C, No. 172, párr. 50.

$66 \mathrm{CIDH}$, Relatoría Especial sobre los Derechos de los Pueblos Indígenas, Informe sobre los Derechos de los pueblos indígenas y tribales, sobre sus tierras ancestrales y recursos naturales, normas y jurisprudencia del sistema interamericano de derechos humanos, OEA/Ser.L/V/II, 30 de diciembre de 2009, párr. 334. 
La posición de la Corte IDH no sólo respecto de la consulta previa, sino de la actuación del Estado frente a invasores, se ha visto a prueba en dos casos: el de los Pueblos Kaliña y Lokono vs. Surinam (2015) — similar al Caso Saramaka (2007) — y el de la Comunidad Garífuna Triunfo de la Cruz y sus miembros vs. Honduras (2015).

En el Caso de los Pueblos Kaliña y Lokono, la Comisión IDH alegó diversas violaciones a los derechos de los miembros de ocho comunidades de esos pueblos indígenas, por la existencia de un marco normativo que les impide, como pueblos, el reconocimiento de la personalidad jurídica, lo cual, a su vez, les impide proteger su derecho a la propiedad colectiva. Además, argumentó que Surinam no ha establecido las bases normativas que permitan un reconocimiento del derecho a la propiedad colectiva de las tierras, territorios y recursos naturales de los pueblos indígenas, lo cual ha sido acompañado de la emisión de títulos de propiedad individuales a favor de personas no indígenas y el otorgamiento de concesiones en reservas naturales para la minería y en parte de sus territorios ancestrales. ${ }^{67}$

Al respecto, la Corte IDH consideró que el Estado debía otorgar el reconocimiento legal de los pueblos mediante la personalidad jurídica colectiva. Esto se debe llevar a cabo mediante la creación de un mecanismo de delimitación, demarcación y titulación de los territorios de los pueblos indígenas y tribales en Surinam, así como adecuar los recursos internos para que las comunidades puedan acceder de manera colectiva a la justicia. ${ }^{68}$

${ }^{67}$ Comisión IDH, Informe No. 79/13, 26 de enero de 2014 (Pueblos Kaliña y Lokono vs. Surinam), en http://www.oas.org/es/cidh/decisiones/ corte/12639FondoEs.pdf.

${ }^{68}$ Corte IDH, Caso Pueblos Kaliña y Lokono vs. Surinam. Fondo, Reparaciones y Costas. Sentencia del 25 de noviembre de 2015. Serie C, No. 309, párr. 305. 
Resulta relevante la referencia de la Corte IDH a la extracción de recursos naturales, pues por primera vez se remite a los Principios de Ruggie (o Principios Rectores sobre las Empresas y los Derechos Humanos) y se impone a los Estados el deber de proteger tanto las áreas de reserva natural como los territorios tradicionales, para prevenir daños en el territorio indígena, inclusive aquel que proceda de terceros, "a través de mecanismos adecuados de supervisión y fiscalización". ${ }^{69}$

En el Caso de la Comunidad Garífuna de Triunfo de la Cruz vs. Honduras, la Comisión IDH alegó que el Estado omitió proteger su territorio ancestral frente a la ocupación y despojo por parte de terceros (tanto personas privadas como autoridades), lo cual —además - ha generado violencia y falta de seguridad en la comunidad. Agregó que la comunidad no tiene título de propiedad idóneo y culturalmente adecuado sobre su territorio ancestral, asimismo, se les ha restringido el acceso a ciertas partes del mismo por la creación de áreas protegidas. Por otro lado, en el caso también se alegó la falta de consulta previa, libre e informada a la comunidad en las decisiones que han afectado su territorio, incluyendo, entre otros, proyectos y megaproyectos turísticos.

Al respecto, la Corte IDH dispuso que el Estado debía demarcar las tierras sobre las cuales había sido otorgada la propiedad colectiva dentro del plazo de dos años. ${ }^{70}$ También refirió que si para cumplir la medida de reparación el Estado debe expropiar o reubicar a terceros, deberá pagar a éstos las indemnizaciones correspondientes. ${ }^{71}$ Sin embargo, la Corte IDH expresó que en caso de que, por motivos debidamente fundados, no fuera

69 Ibidem, párr. 221.

70 Corte IDH, Caso Comunidad Garífuna Triunfo de la Cruz y sus miembros vs. Honduras. Fondo, Reparaciones y Costas. Sentencia del 8 de octubre de 2015. Serie C, No. 305, párr. 259.

71 Ibidem, párr. 261. 
posible titular una porción específica del territorio Garífuna, el Estado debería dar un título de propiedad colectiva a la comunidad sobre tierras alternativas, de igual extensión y calidad que las otorgadas, pero siempre se deberá realizar una consulta a la comunidad para llevar a cabo esta reparación. ${ }^{72}$

\section{VIDA DIGNA}

Un tema no menos trascendental en los casos de pueblos indígenas es el tratamiento de las condiciones de vida de las comunidades, la situación de extrema y especial vulnerabilidad en la que se encuentran, así como la falta de presencia estatal. Es de resaltar el análisis de la Comisión y la Corte Interamericanas en cuanto a la responsabilidad internacional del Estado en relación con el derecho a la integridad personal y a la vida digna, de igual manera respecto a ciertas muertes ocurridas en las comunidades por falta de apoyo asistencial.

Así, por ejemplo, en el Caso del Pueblo Indígena Yanomami de Haximú vs. Venezuela, ${ }^{73}$ seguido ante la Comisión IDH, se refleja la destrucción física sufrida por los indígenas como consecuencia de la intervención, ocupación y desarrollo de su territorio en la Amazonia, por la penetración de personas no indígenas. En el Caso Pueblo Indígena Kichwa de Sarayaku vs. Ecuador, la Corte IDH consideró que la falta de garantía de acceso a la propiedad comunitaria por parte del Estado afectó el derecho a la vida digna de los miembros de la comunidad, por privarlos de sus medios de subsistencia tradicionales y del disfrute de los recursos naturales necesarios para la obtención

72 Ibidem, párr. 262.

$73 \mathrm{CIDH}$, Informe de Solución Amistosa No. 32/12, Petición 11.706, Pueblo Indígena Yanomami de Haximú vs. Venezuela, 20 de marzo de 2012, en https://www.oas.org/es/cidh/decisiones/2012/VESA11706ES.doc. 
de agua limpia y para la práctica de su medicina tradicional de prevención y cura de enfermedades. ${ }^{74}$

Por su parte, los casos paraguayos permiten visualizar el cambio de postura de la Corte IDH al respecto. En el Caso Yakye Axa, donde se alegó que había dieciséis víctimas por causas que podrían haberse evitado con una adecuada alimentación y asistencia médica, y como consecuencia de la falta de respuesta adecuada y oportuna del Estado al reclamo de la comunidad de su tierra ancestral, ${ }^{75}$ la Corte IDH determinó que, al no tener prueba, no podía declarar la violación al derecho a la vida (digna). Sin embargo, consideró que existía una violación al derecho a la vida, pues el Estado no había adoptado medidas positivas concretas y orientadas a disminuir las condiciones de vida en las cuales ya se encontraban los miembros de la comunidad. Es decir, la Corte IDH sólo valoró las medidas que se habían tomado (acción u omisión) ${ }^{76}$ con el conocimiento de la existencia de éstas condiciones y no de aquellas que hubiera prevenido, en un primer momento, que la comunidad se encontrara en una vereda y, como consecuencia, tuviera condiciones de vida contrarias a la dignidad humana.

No obstante, en el Caso Sawhoyamaxa, la Corte IDH cambió de criterio y, además de encontrar la violación del derecho a la vida, por no haber adoptado las medidas necesarias para que los miembros de la comunidad dejaran el costado de la ruta y, por ende, había condiciones inadecuadas que ponían en peligro

74 Corte IDH, Caso Pueblo Indígena Kichwa de Sarayaku vs. Ecuador. Fondo y reparaciones. Sentencia del 27 de junio de 2012. Serie C, No. 245, párr. 147.

75 Corte IDH, Caso Comunidad Indígena Yakye Axa vs. Paraguay. Fondo Reparaciones y Costas. Sentencia del 17 de junio de 2005. Serie C, No. 125, párr. 177.

76 Ibidem, párrs. 162 y 163. 
su derecho a la vida. ${ }^{77}$ También consideró que el Estado violaba el derecho a la vida - a diferencia del Caso Yakye Axa- por no adoptar medidas positivas necesarias [preventivas] dentro del ámbito de sus atribuciones, que razonablemente eran de esperarse para prevenir o evitar el riesgo al derecho a la vida de los miembros de la comunidad. ${ }^{78}$

El Caso Xákmok Kásek difiere de los anteriores por dos aspectos: a) que el Estado paraguayo declaró un estado de emergencia (Decreto No. 1830 de 2009) en la comunidad, por lo que adoptó ciertas medidas a su favor, y b) el análisis que hace la Corte IDH sobre la discriminación de facto a las comunidades indígenas paraguayas.

En cuanto al primer punto, la Corte IDH consideró que el Estado sabía del riesgo real e inmediato del que los miembros de la comunidad indígena eran objeto, por lo que le correspondía evaluar las medidas adoptadas para verificar si se cumplía con su deber de garantía del derecho a la vida. ${ }^{79}$ Para ello, la Corte IDH evaluó en cuatro rubros estas medidas: agua y calidad del agua, alimentación, salud y educación.

En cuanto al primero, la Corte IDH consideró que la cantidad de agua suministrada por el Estado durante el periodo otorgado no superaba los 2.17 litros diarios, cuando los estándares internacionales establecían que el mínimo que requiere una persona para satisfacer sus necesidades básicas diarias es de 7.5 litros. ${ }^{80}$ En cuanto al segundo rubro, la Corte constató que la

77 Corte IDH, Caso Comunidad Indígena Sawhoyamaxa vs. Paraguay. Fondo, Reparaciones y Costas. Sentencia del 29 de marzo de 2006. Serie C, No. 146, párr. 166.

78 Ibidem, párr. 178.

79 Corte IDH, Caso Comunidad Indígena Xákmok Kásek vs. Paraguay. Fondo, Reparaciones y Costas. Sentencia del 24 de agosto de 2010. Serie C, No. 214, párrs. 192 y 193.

80 Ibidem, párr. 195. 
entrega de alimentos no era regular, las raciones alimentarias tenían deficiencias nutricionales y que la mayoría de los miembros comían una sola vez al día, además de que la ración disminuyó. ${ }^{81}$ Respecto del tercer rubro, la Corte notó que las medidas adoptadas a partir del Decreto No. 1830, de 2009, eran temporales y transitorias. Además, el Estado no garantizó a la comunidad la accesibilidad física ni geográfica a establecimientos de salud y, de la prueba aportada, no se evidenciaron acciones positivas para garantizar la aceptabilidad de dichos bienes y servicios, ni que se hubieran desarrollado medidas educativas en materia de salud que sean respetuosas de los usos y costumbres tradicionales. ${ }^{82}$ Finalmente, en cuanto a la educación, existía deserción escolar, las meriendas escolares eran temporales y esporádicas y las instalaciones no eran adecuadas. ${ }^{83} \mathrm{La}$ Corte concluyó que las medidas no habían sido suficientes para superar las condiciones de especial vulnerabilidad. ${ }^{84}$

Así pues, la Corte avanzó en el desarrollo de la jurisprudencia en materia de creación de condiciones dignas de vida, al determinar que el Estado no sólo es responsable internacionalmente, en primer lugar, por no adoptar medidas que prevengan razonablemente estas condiciones, sino que, además, puede ser internacionalmente responsable si, aun habiendo adoptado esas medidas, resultaran ineficaces e insuficientes. ${ }^{85}$

Si bien los derechos que la Corte IDH analizó -y valoró de manera individual - en el Caso Xákmok Kásek se encuentran reconocidos en el Protocolo Adicional a la Convención America-

81 Ibidem, párrs. 199 y 200.

82 Ibidem, párr. 208.

83 Ibidem, párrs. 212 y 213.

84 Ibidem, párr. 214.

85 Véase al respecto lo resuelto por la Corte IDH, Caso Trabajadores de la Hacienda Brasil Verde vs. Brasil. Excepciones Preliminares, Fondo, Reparaciones y Costas. Sentencia del 20 de octubre de 2016. Serie C, No. 318. 
na en materia de Derechos Económicos, Sociales y Culturales (Protocolo de San Salvador), han encontrado su justiciabilidad indirecta a través de los derechos a la vida y a la integridad (artículos 4 y 5 de la Convención Americana) -incluso a través de las amplias reparaciones que otorga la Corte IDH-. Lo anterior se inserta en el debate y la deuda pendiente de la justiciabilidad directa en el Tribunal Interamericano de los Derechos Sociales, de manera genérica en todos los casos, y de manera muy específica en los casos de pueblos indígenas.

\section{DISCRIMINACIÓN}

En la sentencia sobre la desaparición forzada de María y Josefa Tiu Tojín, madre e hija, indígenas mayas K'iche', la Corte IDH hizo referencia a la discriminación a la que fueron sometidos los familiares de las víctimas en su búsqueda de justicia por parte de las autoridades estatales guatemaltecas.$^{86}$ Además, destacó que:

...para garantizar el acceso a la justicia de las víctimas -en tanto miembros del pueblo indígena Maya - y que la investigación de los hechos se realice con la debida diligencia, sin obstáculos y sin discriminación, el Estado debe asegurar que aquellas puedan comprender y hacerse comprender en los procedimientos legales iniciados, facilitándoles intérpretes u otros medios eficaces para tal fin. ${ }^{87}$

86 Corte IDH, Caso Tiu Tojín vs. Guatemala. Fondo, Reparaciones y Costas. Sentencia del 26 de noviembre de 2008. Serie C, No. 190, párrs. 92-100.

87 Ibidem, párr. 100. 
Dando un paso más hacia adelante, y ante el planteamiento expreso de la Comisión IDH, ${ }^{88}$ la Corte determinó en el Caso de la Comunidad Indígena Xákmok Kásek, que el Estado había sometido a sus miembros a discriminación de facto, los había marginalizado en el goce de sus derechos y, además, no había adoptado las medidas positivas necesarias para revertir tal exclusión..$^{89}$ Quizá el elemento más distintivo de esta sentencia es que la Corte IDH destacó que:

...la situación de extrema y especial vulnerabilidad de los miembros de la Comunidad se debe, inter alia, a la falta de recursos adecuados y efectivos que en los hechos proteja los derechos de los indígenas y no sólo de manera formal; la débil presencia de instituciones estatales obligadas a prestar servicios y bienes a los miembros de la Comunidad, en especial, alimentación, agua, salud y educación; y a la prevalencia de una visión de la propiedad que otorga mayor protección a los propietarios privados por sobre los reclamos territoriales indígenas, desconociéndose, con ello, su identidad cultural y amenazando su subsistencia física. Asimismo, quedó demostrado el hecho de que la declaratoria de reserva natural privada sobre parte del territorio reclamado por la Comunidad no tomó en cuenta su reclamo territorial ni tampoco fue consultada sobre dicha declaratoria. ${ }^{90}$

${ }^{88}$ Corte IDH, Caso Comunidad Indígena Xákmok Kásek vs. Paraguay. Fondo, Reparaciones y Costas. Sentencia del 24 de agosto de 2010. Serie C, No. 214, párr. 265.

89 Ibidem, párr. 274.

90 Ibidem, párr. 273. 
En las sentencias de los casos contra México de Inés Fernán$d e z^{91}$ y Valentina Rosendo ${ }^{92}$ — dos mujeres indígenas mep'haa violadas sexualmente por militares, que denunciaron los hechos y cuyos casos fueron conocidos, hasta hace pocos meses, por la jurisdicción militar - la Corte IDH recordó que "Ios Estados deben abstenerse de realizar acciones que de cualquier manera vayan dirigidas, directa o indirectamente, a crear situaciones de discriminación de jure o de facto", ${ }^{93}$ y destacó que para garantizar el acceso a la justicia de los miembros de los pueblos indígenas es "indispensable que los Estados otorguen una protección efectiva que tome en cuenta sus particularidades propias, sus características económicas y sociales, así como su situación de especial vulnerabilidad, su derecho consuetudinario, valores, usos y costumbres". ${ }^{94}$

Por otro lado, en su demanda en el Caso Norín Catriman y otros (Dirigentes, miembros y activista del Pueblo Indígena Mapuche) vs. Chile, en el que varios indígenas, líderes indígenas y defensores de indígenas fueron juzgados por el delito de terrorismo por haber, supuestamente, incendiado un predio, la Comisión IDH consideró, al analizar el proceso al que fueron sometidas dichas personas, que "si la raza o el origen étnico de una persona es tomado en cuenta como elemento para ca-

91 Corte IDH, Caso Fernández Ortega y otros vs. México. Excepción Preliminar, Fondo, Reparaciones y Costas. Sentencia del 30 de agosto de 2010. Serie C, No. 215.

92 Corte IDH, Caso Rosendo Cantú y otra vs. México. Excepción Preliminar, Fondo, Reparaciones y Costas. Sentencia del 31 de agosto de 2010. Serie C, No. 216.

93 Corte IDH, Caso Fernández Ortega y otros vs. México. Excepción Preliminar, Fondo, Reparaciones y Costas. Sentencia del 30 de agosto de 2010. Serie C, No. 215, párr. 200, y Corte IDH, Caso Rosendo Cantú y otra vs. México. Excepción Preliminar, Fondo, Reparaciones y Costas. Sentencia del 31 de agosto de 2010. Serie C, No. 216, párr. 184.

94 Ibidem. 
Este libro forma parte del acervo de la Biblioteca Jurídica Virtual del Instituto de Investigaciones Jurídicas de la UNAM

lificar un hecho normalmente considerado delito común como un delito terrorista, se estaría ante un escenario de aplicación selectiva de la ley penal"..$^{95}$

Además, la Comisión IDH alegó que dicha aplicación selectiva configuraba una diferencia de trato frente a otras personas, y al incluir el criterio de pertenencia étnica - considerada como categoría sospechosa - era necesario realizar un "escrutinio especialmente estricto", independientemente de que en las decisiones internas se hubieran considerado otros elementos distintos para llegar a las conclusiones respectivas. La Comisión concluyó que, al calificar los hechos como delitos terroristas, tomando en cuenta la pertenencia y/o el vínculo de las víctimas del caso con el pueblo indígena Mapuche, sin fundamentación de la relación directa de los hechos investigados y los alegados actos de violencia cometidos por grupos minoritarios del pueblo, constituyó un acto de discriminación. ${ }^{96}$

En su sentencia, en relación con el alegato relativo a la aplicación selectiva de la Ley 18.314, que determina conductas terroristas y fija su penalidad, mejor conocida como "La Ley Antiterrorista", contra los miembros del pueblo Mapuche, la Corte IDH reconoció que, en efecto, doce de diecinueve causas bajo la Ley Antiterrorista se relacionaban con las reivindicaciones Mapuches, y destacó que tanto el Relator Especial de los Pueblos Indígenas como el Relator Especial contra el Terrorismo, así como los Comités de Naciones Unidas, han manifestado su preocupación por la aplicación desproporcionada de

${ }^{95}$ Citado en Corte IDH, Caso Norín Catrimán y otros (Dirigentes, miembros y activista del Pueblo Indígena Mapuche) vs. Chile. Fondo, Reparaciones y Costas. Sentencia del 29 de mayo de 2014. Serie C, No. 279, párr. 189; CIDH, Informe de Fondo 176/10, Norín Catriman y otros vs. Chile, 7 de agosto de

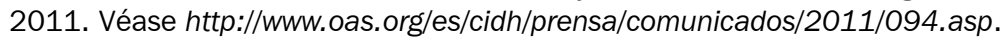

${ }_{96} \mathrm{CIDH}$, Informe de Fondo No. 176/10, Segundo Aniceto Norín Catriman, Juan Patricio Marileo Saravia, Victor Ancalaf Llaupe y otros vs. Chile, 5 de noviembre de 2010, párrs. 170 y ss. 
dicha ley a los miembros del pueblo Mapuche. ${ }^{97}$ Sin embargo, en un salto argumentativo que no se entiende en la decisión, la Corte IDH consideró que "la mayor aplicación a miembros del Pueblo Indígena Mapuche de esa ley penal... no permite concluir que se ha dado la alegada aplicación selectiva de carácter discriminatorio". ${ }^{98}$ Como en varios de los últimos casos decididos por la Corte IDH, éste es renuente a reconocer patrones estructurales.

Pese a lo anterior, en el apartado en el que analizó las decisiones judiciales que condenaron a las víctimas del caso, la Corte IDH destacó lo siguiente en cuanto a la discriminación en las mismas:

Puede haber una aplicación discriminatoria de la ley penal si el juez o tribunal condena a una persona basándose en un razonamiento fundado en estereotipos negativos que asocien a un grupo étnico con el terrorismo para determinar alguno de los elementos de la responsabilidad penal. Incumbe al juez penal verificar que todos los elementos del tipo penal hayan sido probados por la parte acusadora, puesto que, como ha expresado esta Corte, la demostración fehaciente de la culpabilidad constituye un requisito indispensable para la sanción penal, de modo que la carga de la prueba recaiga, como corresponde, en la parte acusadora y no en el acusado..$^{99}$

Los estereotipos constituyen pre-concepciones de los atributos, conductas, papeles o características poseídas por personas que pertenecen a un grupo identificado... Asimismo, la Corte ha indicado que las condiciones discriminatorias

97 Corte IDH, Caso Norín Catrimán y otros (Dirigentes, miembros y activista del Pueblo Indígena Mapuche) vs. Chile. Fondo, Reparaciones y Costas. Sentencia del 29 de mayo de 2014. Serie C, No. 279, párr. 218.

98 Ibidem, párrs. 217-221.

99 Ibidem, párr. 223. 
“basadas en estereotipos... socialmente dominantes y socialmente persistentes... se agravan cuando los estereotipos se reflejan, implícita o explícitamente, en políticas y prácticas, particularmente en el razonamiento y el lenguaje de [las autoridades]...". ${ }^{100}$

La Corte IDH analizó las decisiones judiciales del caso concreto tomando en cuenta el contexto en el que se produjeron, y observó cómo se utilizó un lenguaje cargado de estereotipos de lo que - para los juzgadores nacionales - era el pueblo Mapuche y el comportamiento que sus miembros tendrían. Por tanto, concluyó que los razonamientos de las decisiones denotaron estereotipos y prejuicios que constituyeron una violación al principio de igualdad y no discriminación y al derecho a la igual protección ante la ley.

\section{LIBERTAD DE CONCIENCIA Y RELIGIÓN ${ }^{101}$}

El derecho a la libertad de conciencia y religión ha sido poco desarrollado en el Sistema Interamericano. No obstante, las escasas referencias existentes se dan, mayoritariamente, en casos relacionados con pueblos indígenas. En ese sentido, cabe destacar la demanda del Caso de la Masacre Plan de Sánchez vs. Guatemala, ${ }^{102}$ en la que la Comisión alegó que para los pueblos indígenas, el derecho a la cultura y a su identidad étnica se traducen, en general, en la expresión y la preservación, entre otros, de

\section{Ibidem, párr. 224.}

101 La información contenida en este subapéndice está contenida en un artículo más extenso, en proceso de publicación, sobre el derecho a la libertad de conciencia y religión en el Sistema Interamericano.

${ }_{102} \mathrm{CIDH}$, demanda en el caso de la Masacre de Plan de Sánchez vs. Guatemala, 25 de octubre de 1996, en http://www.corteidh.or.cr/cf/Jurisprudencia2/ver_expediente.cfm?nld_expediente $=39 \& / a n g=e s$. 
creencias y lugares sagrados. Asimismo, la Comisión IDH alegó que existía violación del derecho a la libertad de conciencia y religión, en términos más generales, en virtud de que la comunidad indígena del pueblo maya de Plan de Sánchez se vio impedida, por miedo, a practicar sus creencias antes y después de la masacre. Además, en términos específicos, consideró que el Estado había vulnerado los derechos de los miembros de la comunidad, por la sepultura indigna que se hizo de los restos mortales de la gente masacrada en Plan de Sánchez y por el hecho de que los miembros del pueblo indígena no pudieron sepultarlos conforme a sus costumbres y creencias. En la sentencia de fondo de la Masacre Plan de Sánchez vs. Guatemala, en virtud de la aceptación de responsabilidad internacional y al allanamiento de los hechos y al derecho alegado por la Comisión IDH en su demanda, la Corte, si bien hizo referencia a dicho artículo y lo consideró como violado, no realizó consideraciones jurídicas concretas. ${ }^{103}$

Por otro lado, la visión flexible que ha tenido la Corte IDH, con relación al derecho a la integridad personal, ha permitido incluir, en el análisis del mismo, cuestiones que podrían caber en el contenido de otros derechos, como es el caso de la libertad de conciencia y religión. Así, por ejemplo, en el Caso Bámaca Velásquez vs. Guatemala, la Corte consideró que los familiares tenían derecho a sepultar dignamente los restos mortales de la persona forzadamente desaparecida, debido a su "repercusión en la cultura maya". ${ }^{104}$ Además, la Corte destacó que el cuidado de los restos mortales "observado en todas las culturas, asume una significación muy especial en la cultura maya [pues para ésta] las honras fúnebres aseguran la posibilidad de un reencuentro entre las generaciones de los vivos, la persona fallecida

103 Corte IDH, Caso Masacre Plan de Sánchez vs. Guatemala. Fondo. Sentencia del 29 de abril de 2004. Serie C, No. 105.

104 Corte IDH, Caso Bámaca Velásquez vs. Guatemala. Reparaciones y Costas. Sentencia del 22 de febrero de 2002. Serie C, No. 91, párr. 79. 
y los antepasados muertos". ${ }^{105}$ Finalmente, en el Caso de la Comunidad Moiwana vs. Surinam, la Corte consideró, en un sentido similar, que los sobrevivientes no pudieron honrar y enterrar a sus seres queridos según su cultura N'djuka. ${ }^{106}$

En el Caso Masacres de Río Negro vs. Guatemala, en el que más de quinientas personas fueron ejecutadas, la Corte concluyó que el Estado era responsable de la destrucción de su estructura social, la desintegración familiar y la pérdida de las prácticas culturales y tradicionales de los miembros de la comunidad indígena maya achí de Río Negro. ${ }^{107}$ Además, recordó que:

...la relación especial de los pueblos indígenas con sus territorios ancestrales no estriba solamente en que constituyen su principal medio de subsistencia, sino un elemento integrante de su cosmovisión, religiosidad ${ }^{108} \mathrm{y}$, por ende, de su identidad... o integridad cultural, el cual es un derecho fundamental y de naturaleza colectiva de las comunidades indígenas, que debe ser respetado en una sociedad multicultural, pluralista y democrática. ${ }^{109}$

Por tanto, concluyó que el Estado era responsable de la violación al derecho a la integridad personal de los miembros de la comunidad de Río Negro, en relación con el derecho a

105 Ibidem, párr. 81.

106 Corte IDH, Caso de la Comunidad Moiwana vs. Surinam. Excepciones Preliminares, Fondo, Reparaciones y Costas. Sentencia del 15 de junio de 2005. Serie C, No. 124, párr. 100.

107 Corte IDH, Caso Masacres de Río Negro vs. Guatemala. Excepción Preliminar, Fondo, Reparaciones y Costas. Sentencia del 4 de septiembre de 2012. Serie C, No. 250, párr. 162.

108 Desde nuestro punto de vista, hubiera sido mejor utilizar el término espiritualidad.

109 Corte IDH, Caso Masacres de Río Negro vs. Guatemala. Excepción Preliminar, Fondo, Reparaciones y Costas. Sentencia del 4 de septiembre de 2012. Serie C, No. 250, párr. 160. 
la libertad de conciencia y religión, constituyendo éste el primer caso en el que hace referencia directa a tal derecho, aun cuando expresó que la Convención Americana no contiene "un derecho a enterrar a los muertos". ${ }^{110}$

Sin embargo, pese a haber dado este avance jurisprudencial en el Caso Miembros de la Aldea Chichupac y comunidades vecinas del Municipio de Rabinal vs. Guatemala, la Corte IDH no hizo un pronunciamiento autónomo y declaró la no violación del artículo 12 de la CADH frente a las alegaciones que habían realizado las víctimas, con el argumento de que al haber sido desplazadas de sus territorios no habían podido practicar su cultura. ${ }^{111}$

\section{DERECHO DE PARTICIPACIÓN POLÍTICA}

Ya en un informe de 1997, la Comisión IDH estableció que la protección de los pueblos indígenas requiere que los Estados tomen las medidas necesarias para garantizar la participación significativa y efectiva de los representantes indígenas en los procesos de

${ }^{110}$ En este entendido, la Corte IDH consideró: “155. La Convención Americana no contempla explícitamente el derecho de "enterrar a los muertos". La Corte Interamericana ha abordado este tema no como un derecho sustantivo, sino en el marco de las reparaciones en casos de desapariciones forzadas, principalmente, como consecuencia de la vulneración de algún otro derecho que sí esté previsto en la Convención...". Corte IDH, Caso Masacres de Río Negro vs. Guatemala. Excepción Preliminar, Fondo, Reparaciones y Costas. Sentencia del 4 de septiembre de 2012. Serie C, No. 250, párrs. 155 y 165.

${ }^{111}$ Corte IDH, Caso Miembros de la Aldea Chichupac y comunidades vecinas del Municipio de Rabinal vs. Guatemala. Excepciones Preliminares, Fondo, Reparaciones y Costas. Sentencia del 30 de noviembre de 2016. Serie C, No. 328, párrs. 194-202 y 204. 
Este libro forma parte del acervo de la Biblioteca Jurídica Virtual del Instituto de Investigaciones Jurídicas de la UNAM

toma de decisiones acerca del desarrollo y otros temas que los afectan a ellos y a su supervivencia cultural. ${ }^{112}$

El caso más representativo de la participación política de los miembros de pueblos indígenas en el Sistema Interamericano es el Caso Yatama vs. Nicaragua, en el cual la Corte IDH reconoció el derecho de los pueblos indígenas para participar, de manera directa y proporcional a su población, en la dirección de los asuntos públicos del país, sin necesidad de afiliarse a un partido y desde sus propias instituciones, de acuerdo con sus valores, usos, costumbres y formas de organización, siempre que éstos sean compatibles con los derechos humanos reconocidos en la Convención. ${ }^{113}$

En el Caso del Pueblo Saramaka vs. Surinam, la Corte IDH hizo referencia a la participación de los pueblos indígenas en el proceso de consulta, pero no incluyó expresamente el derecho a la participación política. En su demanda del Pueblo Indígena Kichwa de Sarayaku vs. Ecuador, la Comisión IDH consideró que el derecho de consulta involucraba, además del derecho a la propiedad, los derechos a la participación política y al acceso a la información. Específicamente, la Comisión consideró que "el derecho a la consulta previa es una dimensión del ejercicio de los derechos políticos de los Pueblos Indígenas, como el medio para garantizar la participación significativa y efectiva de los Pueblos Indígenas en los procesos de toma de decisiones acerca del desarrollo y de otros temas que los afecten". ${ }^{114}$

$112 \mathrm{CIDH}$, Informe sobre la situación de los derechos humanos en Brasil, 29 de septiembre de 1997, OEA/Ser.L/V/II.97, Doc. 29, rev. 1, párr. 63 y ss., en http://www.cidh.org/countryrep/Brasesp97/capitulo_6\%20.htm.

113 Corte IDH, Caso Yatama vs. Nicaragua. Excepciones Preliminares, Fondo, Reparaciones y Costas. Sentencia del 23 de junio de 2005. Serie C, No. 127, párr. 225.

$114 \mathrm{CIDH}$, Demanda ante la Corte Interamericana de Derechos Humanos en el caso del Pueblo Indígena Kichwa de Sarayaku y sus miembros (Caso 
En ese sentido, durante la audiencia pública del Caso Pueblo Indígena Kichwa de Sarayaku vs. Ecuador ante la Corte IDH, el Relator de Naciones Unidas para los Pueblos Indígenas manifestó, en relación con la participación política de los pueblos indígenas en los procesos de consulta, que éstos tienen el derecho de "determinar sus propios destinos al igual que los demás seres humanos", para lo cual deben respetarse las estructuras de autoridad tradicional, la cultura indígena y el derecho consuetudinario. ${ }^{115}$

En su sentencia, la Corte IDH, si bien hace referencia al acceso a la información que deben tener los pueblos indígenas en los procesos de consulta, no consideró necesario hacer un análisis jurídico del derecho a la participación e información, puesto que consideró que ya habían sido abordados en el análisis del derecho de consulta. ${ }^{116}$

Recientemente, en el Caso Pueblos Kaliña y Lokono vs. Surinam, la Corte IDH sí se pronunció sobre la participación efectiva de consulta -aplicando el principio iura novit curia pues las partes no alegaron la violación de éste derecho- ${ }^{117}$ y determinó que la falta de ésta deriva de la violación del artículo 23 de la CADH y consideró que:

12.465) vs. Ecuador, 26 de abril de 2010, párr. 159, en http://cidh.org/demandas/12.465\%20Sarayaku\%20Ecuador\%2026abr2010\%20ESP.pdf.

115 Audiencia Pública ante la Corte Interamericana del Caso Kichwa de Sarayaku vs. Ecuador, en http://www.corteidh.or.cr/index.php/es/al-dia/galeriamultimedia?start $=40$.

116 Corte IDH, Caso Pueblo Indígena Kichwa de Sarayaku vs. Ecuador. Fondo y reparaciones. Sentencia del 27 de junio de 2012. Serie C, No. 245, parr. 230.

117 Corte IDH, Caso Pueblos Kaliña y Lokono vs. Surinam. Fondo, Reparaciones y Costas. Sentencia del 25 de noviembre de 2015. Serie C, No. 309, párr. 126. 
...el artículo 23 de la Convención Americana dispone el deber de gozar de los derechos y oportunidades "de participar en la dirección de los asuntos públicos...". En este sentido, la participación en la conservación del medio ambiente para las comunidades indígenas resulta no sólo en un asunto de interés público sino parte del ejercicio de su derecho como pueblos indígenas a participar en la adopción de decisiones en las cuestiones que afectan sus derechos, de conformidad con sus propios procedimientos e instituciones.

En vista de ello, a fin de garantizar el uso y goce del derecho a la propiedad colectiva indígena, conforme a los artículos 1.1 y 21 de la Convención, frente a la utilización o explotación de recursos naturales en su territorio tradicional, el Estado debe, para efectos del presente caso, contar con mecanismos para garantizar la participación efectiva de los pueblos indígenas, a través de procedimientos culturalmente adecuados para la toma de decisiones de dichos pueblos. Lo anterior no sólo consiste en un asunto de interés público, sino que también forma parte del ejercicio de su derecho a participar en la adopción de decisiones en las cuestiones que afectan sus intereses, de conformidad con sus propios procedimientos e instituciones, en relación con el artículo 23 de la Convención Americana. ${ }^{118}$

De esta manera, y en este caso, por primera vez la Corte IDH enmarcó la violación del derecho a la consulta en otro artículo diferente al 21, y lo denominó participación efectiva de consulta; ${ }^{119}$ sin embargo, como advierten dos jueces, la nomenclatura en nada afecta el contenido esencial del derecho. ${ }^{120}$

118 Ibidem, párrs. 196 y 203.

119 Ibidem, párr. 230.

120 Véase el Voto Concurrente a la Sentencia de los Jueces Humberto Sierra Porto y Eduardo Ferrer Mac-Gregor Poisot. 


\section{MUJERES INDÍGENAS}

Los Casos Fernández Ortega y otra y Rosendo Cantú y otra vs. México representan un paso fundamental en cuanto al reconocimiento, por parte de la Corte IDH, de la violación sexual como tortura. Además, tal como quedó referenciado en el acápite de discriminación, la Corte determinó que el trato brindado por las autoridades estatales a las víctimas constituyó un trato discriminatorio. Por otro lado, cabe destacar que en audiencia pública ante la Comisión IDH, en el 144 periodo de sesiones, un grupo de mujeres indígenas de la región -incluyendo mujeres de Colombia, Argentina y Canadá- destacaron la importancia de los casos de Inés Fernández y Valentina Rosendo como mujeres y como indígenas, pero manifestaron su preocupación de que el elemento colectivo no se habría visto reflejado en la sentencia. En ese sentido, en una crítica constructiva, refirieron la necesidad de que los órganos del Sistema Interamericano aborden casos futuros desde la integralidad de la mujer indígena perteneciente a un grupo indígena. ${ }^{121}$

Años antes de las sentencias en los casos de Inés Fernández y Valentina Rosendo, la Comisión IDH emitió un informe en el Caso Ana, Beatriz y Celia González Pérez, también contra México. ${ }^{122}$ Las indígenas tzetzales fueron sometidas por un grupo de militares a un interrogatorio ilegal, en medio de abusos físicos que incluyeron la violación sexual en 1994. El caso no fue conocido por la Corte IDH.

121 Audiencia pública ante la Comisión IDH durante el 144 Periodo de Sesiones sobre Discriminación Contra las Mujeres Indígenas en las Américas, 28 de marzo de 2012, en http://www.oas.org/es/cidh/audiencias/hearings.aspx?la $n g=$ es\&session $=125 \&$ page $=2$.

122 CIDH, Informe No. 53/01, Caso 11.656. Ana, Beatriz y Celia González Pérez vs. México, 4 de abril de 2001, en http://www.cidh.org/annualrep/2000sp/ capituloiii/fondo/Mexico11.565.htm. 
Finalmente, es importante destacar que el Caso Comunidad Indígena Xákmok Kásek vs. Paraguay fue la primera sentencia en el ámbito internacional en abordar el tema de la mortandad materna debida a la extrema pobreza y la falta de adecuada atención médica, así como en destacar las obligaciones de los Estados para brindar políticas adecuadas de salud a las mujeres. ${ }^{123}$

\section{DeSPLAZAMIENTO FORZADO}

En el Caso de las Masacres de Río Negro vs. Guatemala, la Corte IDH dio por probado que los miembros de la comunidad se vieron forzados a huir de sus tierras luego de las masacres cometidas en su contra, e impedidos a regresar a las mismas por el contexto de conflicto armado que se vivía en el país, así como por la construcción de una represa sobre su territorio. Por tanto, concluyó que la persecución sistemática y el desplazamiento provocaron afectaciones en los sobrevivientes de las mismas. ${ }^{124}$ En ese sentido, la Corte destacó que:

...el desplazamiento forzado de los pueblos indígenas fuera de su comunidad o bien de sus integrantes, los puede colocar en una situación de especial vulnerabilidad, que "[p]or sus secuelas destructivas sobre el tejido étnico y cultural... genera un claro riesgo de extinción, cultural o físico, de los pueblos indígenas"... por lo cual es indispensable que los Estados adopten medidas específicas de protección... considerando las particularidades propias de los pueblos indíge-

123 Corte IDH, Caso Comunidad Indígena Xákmok Kásek vs. Paraguay. Fondo, Reparaciones y Costas. Sentencia del 24 de agosto de 2010. Serie C, No. 214, párr. 233.

124 Véase peritaje rendido por Rosalina Tuyuc en la audiencia pública celebrada el 19 y 20 de junio de 2012, en http://vimeo.com/album/1983401. 
nas, así como su derecho consuetudinario, valores, usos y costumbres... para prevenir y revertir los efectos de dicha situación. ${ }^{125}$

La Corte concluyó que si bien el país había realizado esfuerzos para reasentar a los sobrevivientes de las masacres, no había "establecido las condiciones ni proporcionado los medios indispensables para reparar o mitigar los efectos de su desplazamiento, provocado por el propio Estado". ${ }^{126}$

Como ya se destacó anteriormente, en el Caso de los Pueblos Indígenas Kuna de Madungandí y Emberá de Bayano y sus miembros vs. Panamá, la Corte IDH eludió varios de los temas planteados - algunos de los cuales consideró fuera de su competencia sin hacer un análisis de la violación continuada-, uno de ellos era el desplazamiento al que se vieron obligados los miembros de dichos pueblos. ${ }^{127}$

Ahora bien, un caso de especial significación es el Caso de las comunidades afrodescedientes desplazadas de la Cuenca del Río Cacarica (Operación Génesis) vs. Colombia - este caso se refería a comunidades tribales afrodescendientes-, en el cual se protegió, por primera vez, el artículo 21 de la Convención Americana aplicando el Derecho Internacional Humanitario por Conflicto Armado no Internacional. Eran dos los principales alegatos: las afectaciones (individuales y colectivas) de las co-

125 Corte IDH, Caso Masacres de Río Negro vs. Guatemala. Excepción Preliminar, Fondo, Reparaciones y Costas. Sentencia del 4 de septiembre de 2012. Serie C, No. 250, párr. 177.

126 Corte IDH, Caso Masacres de Río Negro vs. Guatemala. Excepción Preliminar, Fondo, Reparaciones y Costas. Sentencia del 4 de septiembre de 2012. Serie C, No. 250, párr. 169.

127 Corte IDH, Caso de los Pueblos Indígenas Kuna de Madungandí y Emberá de Bayano y sus miembros vs. Panamá. Excepciones Preliminares, Fondo, Reparaciones y Costas. Sentencia del 14 de octubre de 2014. Serie C, No. 284. 
munidades de la Cuenca del Río Cacarica (vivienda), y la presunta explotación ilegal de los territorios del Consejo Comunitario de dichas comunidades. ${ }^{128}$

Al tratarse de un pueblo tribal, la Corte IDH recordó que en el contexto del derecho a la propiedad de los miembros de los pueblos indígenas y tribales, el artículo 21 protege la vinculación estrecha de éstos con la tierra, lo recursos naturales de los territorios ancestrales y los elementos incorporales que se desprendan de ellos, por lo que, debido a esa conexión intrínseca de los integrantes de los pueblos indígenas y tribales con su territorio, la protección de la propiedad, uso y goce sobre éste, es necesaria para garantizar su supervivencia. ${ }^{129} \mathrm{Al}$ hacer dicho análisis, la Corte IDH invocó las normas 7a. y 133 del Derecho Internacional Humanitario Consuetudinario, la última de las cuales estipula que "deberán respetarse los derechos de propiedad de las personas desplazadas". ${ }^{130}$

Con relación al derecho a la vivienda, la Corte IDH constató la destrucción de los hogares de los pobladores de las comunidades, lo que originó que además de constituir una gran pérdida de carácter económico, les causara una pérdida de sus condiciones básicas de existencia, lo cual hacía que la violación al derecho a la propiedad fuera de especial gravedad. ${ }^{131}$

Asimismo, la Corte IDH consideró que existía una violación al derecho a la propiedad colectiva indígena por el desplazamiento que habían sufrido las comunidades, la falta de acceso a sus

128 Corte IDH, Caso de las Comunidades afrodescendientes desplazadas de la Cuenca del Río Cacarica (Operación Génesis) vs. Colombia. Excepciones Preliminares, Fondo, Reparaciones y Costas. Sentencia del 20 de noviembre de 2013. Serie C, No. 270, párr. 344.

129 Ibidem, párr. 346.

130 Ibidem, párr. 349.

131 Ibidem, párr. 352. 
tierras y que las actividades de explotación de recursos fueron ilegales en ese territorio. ${ }^{132}$

\section{Personalidad JuRídicA de LOS Miembros Y PUEBLOS INDÍGENAS Y TRIBALES}

Un tema muy relevante dentro de la temática indígena y tribal en la jurisprudencia interamericana ha sido la personalidad jurídica de sus miembros, así como del concepto de pueblo. En este sentido, la Corte IDH ha enmarcado la violación de este derecho a la luz del artículo 3o. de la Convención Americana. Del acervo jurisprudencial se pueden identificar tres vertientes respecto del tratamiento de este derecho: a) reconocimiento de la personalidad jurídica de manera colectiva para ejercer sus derechos colectivos; b) los "pueblos indígenas y tribales" como sujetos de derechos diferenciados de sus miembros como víctimas, y c) la falta de registros (actas de nacimiento) de miembros de comunidades indígenas.

En cuanto al primer punto, en el Caso del Pueblo Saramaka vs. Surinam, la Corte IDH reconoció el derecho a la personalidad jurídica del pueblo, dándoles un reconocimiento que les permitiera elegir a sus propios representantes, sobre quienes recaería la responsabilidad de las decisiones que afectaran a la comunidad en su conjunto. ${ }^{133}$ Además, la Corte consideró que dicho pueblo:

132 Ibidem, párrs. 256 y 257.

133 Corte IDH, Caso del Pueblo Saramaka vs. Surinam. Excepciones Preliminares, Fondo, Reparaciones y Costas. Sentencia del 28 de noviembre de 2007. Serie C, No. 172, párr. 169. 
...era entidad tribal distintiva que se encontraba en una situación de vulnerabilidad, tanto respecto del Estado así como de terceras partes privadas, en tanto que carecían de capacidad jurídica para gozar, colectivamente, del derecho a la propiedad y para reclamar la presunta violación de dicho derecho ante los tribunales internos. La Corte consideró que el Estado debía reconocer a los integrantes del pueblo Saramaka dicha capacidad para ejercer plenamente estos derechos de manera colectiva. ${ }^{134}$

Sin embargo, este reconocimiento constituyó un obiter dicta y no fue plasmado en la ratio decidendi. ${ }^{135}$ Esta situación fue diferente en el Caso Pueblos Kaliña y Lokono vs. Surinam, pues en este caso sí se consideró que la violación por la falta de ejercicio de la personalidad jurídica recaía tanto en el pueblo (al ser una colectividad) así como en sus miembros (individuales). ${ }^{136}$

Ahora bien, en relación con la personalidad jurídica de los pueblos indígenas como posibles víctimas de violación a sus derechos humanos en el Sistema Interamericano, el primer caso en donde la Corte IDH hizo este análisis diferenciado fue en el Caso Pueblo Indígena Kichwa de Sarayaku vs. Ecuador. Pese a que fue constantemente alegado por la Comisión IDH en casos anteriores, fue hasta esta sentencia que la Corte IDH determinó que el pueblo —y no sólo sus miembros - fue víctima de violaciones a sus derechos humanos por parte del Estado ecuatoriano. ${ }^{137}$ Esta postura se reafirmó en la Opinión Consultiva No. 22 sobre

134 Ibidem, párr. 174.

135 En los resolutivos de la sentencia, la Corte IDH hizo alusión a la violación del artículo 3o. sólo refiriéndose a los "miembros".

136 En los resolutivos de la sentencia, la Corte IDH hizo alusión a la violación del artículo 3o. sólo refiriéndose a los "pueblos" y a los "miembros".

137 Corte IDH, Caso Pueblo Indígena Kichwa de Sarayaku vs. Ecuador. Fondo y Reparaciones. Sentencia del 27 de junio de 2012. Serie C, No. 245, resolutivos 2 y 4 . 
Titularidad de Derechos de las Personas Jurídicas en el Sistema Interamericano de Derechos Humanos, en la que la Corte IDH insistió en que los pueblos indígenas son entes colectivos de derecho internacional y tienen que ser considerados de manera colectiva, ${ }^{138}$ lo cual podría considerarse una excepción al artículo 1.2 de la Convención Americana. Así, concluye que:

De acuerdo a lo anterior, la Corte concluye que, por disponerlo varios instrumentos jurídicos internacionales, de los que son partes los Estados del sistema interamericano, y algunas de sus legislaciones nacionales, las comunidades indígenas y tribales, por encontrarse en una situación particular, deben ser consideras como titulares de ciertos derechos humanos. Adicionalmente, ello se explica en atención a que, en el caso de los pueblos indígenas su identidad y ciertos derechos individuales, como por ejemplo el derecho a la propiedad o a su territorio, solo pueden ser ejercidos por medio de la colectividad a la que pertenecen. ${ }^{139}$

En cuanto a la falta de registros de nacimiento, en el Caso Comunidad Indígena Sawhoyamaxa vs. Paraguay, la Corte IDH se enteró del fallecimiento de 18 personas por el incumplimiento del Estado de su deber de prevención, y manifestó, además, que dichas personas no habían contado con registros de su nacimiento o defunción, ni con algún otro documento proveído por el Estado capaz de demostrar su existencia e identidad. Igualmente, la Corte IDH destacó que de los hechos se desprendía

138 Corte IDH, Titularidad de derechos de las personas jurídicas en el Sistema Interamericano de Derechos Humanos (Interpretación y alcance del artículo 1.2, en relación con los artículos 1.1, 8, 11.2, 13, 16, 21, 24, 25, 29, 30, 44, 46, y 62.3 de la Convención Americana sobre Derechos Humanos, así como del artículo 8.1 A y $B$ del Protocolo de San Salvador). Opinión Consultiva OC-22/16 del 26 de febrero de 2016. Serie A, No. 22, párr. 72-84.

139 Ibidem, párr. 83. 
que los miembros de la comunidad vivían en condiciones de extremo riesgo y vulnerabilidad, por lo que tenían serios impedimentos económicos y geográficos para obtener el debido registro de nacimientos y defunciones, así como otros documentos de identidad. En suma, la Corte IDH apuntó que los miembros de la comunidad habían permanecido en un limbo legal en que, si bien habían nacido o muerto en el Paraguay, su existencia misma e identidad nunca estuvo jurídicamente reconocida; es decir, que no tenían personalidad jurídica. ${ }^{140}$ Esta situación se reiteró en el Caso Comunidad Indígena Xákmok Kásek vs. Paraguay, ${ }^{141}$ así como en el Caso Masacres de Río Negro vs. Guatemala.

\section{OTROS TEMAS SUSTANTIVOS:}

INTEGRIDAD CULTURAL, USO DEL IDIOMA E IDENTIDAD CULTURAL

Existen, sin duda, muchas más aristas en los casos relativos a derechos de los pueblos indígenas; baste con dejar mencionadas tanto las masacres como la afectación a la integridad cultural.

En ese sentido, se debe destacar el tratamiento que el Sistema Interamericano ha dado a los casos de masacres de comunidades indígenas, principalmente en Guatemala. Así, por ejemplo, en los Casos Masacre Plan de Sánchez y Masacres de Río Negro, la CIDH solicitó que la Corte analizara los casos tomando en consideración el contexto de genocidio en el cual se dieron.

140 Corte IDH, Caso Comunidad Indígena Sawhoyamaxa vs. Paraguay. Fondo, Reparaciones y Costas. Sentencia del 29 de marzo de 2006. Serie C, No. 146, párrs. 191, 192 y 193

${ }^{141}$ Corte IDH, Caso Comunidad Indígena Xákmok Kásek vs. Paraguay. Fondo, Reparaciones y Costas. Sentencia del 24 de agosto de 2010. Serie C, No. 214, párrs. 245-254. 
Otro tema de relevancia ha sido la afectación a la integridad cultural sufrida por miembros de comunidades indígenas como consecuencia de las violaciones a sus derechos, tema abordado principalmente en el Caso de Florencio Chitay Nech, líder indígena desaparecido en Guatemala. ${ }^{142}$ En la sentencia, la Corte IDH realizó —al igual que en otros casos de desaparición - un análisis de los efectos y violaciones que causó dicho abuso múltiple y continuado, con las implicaciones personales, comunitarias y culturales que la desaparición tuvo en su familia, principalmente en sus hijos menores de edad — quienes tuvieron que desplazarse y negar sus orígenes - y en su comunidad, al perder a uno de sus líderes.

Otro tema trascendental dentro del contexto indígena es el relativo al uso del idioma, que ha sido desarrollado en los Casos López Álvarez vs. Honduras y Chitay Nech y otros vs. Guatemala. En el Caso López Álvarez, la Corte encontró que al prohibir a Alfredo López Álvarez expresarse en el idioma de su elección - en su lengua como miembro de una comunidad garífuna-, durante su detención en el Centro Penal de Tela, el Estado aplicó una restricción al ejercicio de su libertad de expresión, incompatible con la garantía prevista en la Convención y que, a su vez, constituyó un acto discriminatorio en su contra. ${ }^{143}$ En ese sentido, recordó que los Estados deben tomar en consideración los datos que diferencian a los miembros de pueblos indígenas de la población en general, y que conforman la identidad cultural de aquéllos ${ }^{144}$ y agregó que la lengua es uno de los más importantes elementos de identidad de un pueblo, precisamen-

142 Corte IDH, Caso Chitay Nech y otros vs. Guatemala. Excepciones Preliminares, Fondo, Reparaciones y Costas. Sentencia del 25 de mayo de 2010. Serie C, No. 212.

143 Caso López Álvarez vs. Honduras. Fondo, Reparaciones y Costas. Sentencia del 1 de febrero de 2006. Serie C, No. 141, párr. 173.

144 Ibidem, párr. 171. 
te porque garantiza la expresión, difusión y transmisión de su cultura. ${ }^{145}$ En el presente caso, la restricción al ejercicio de la libertad de hablar su idioma, aplicada también a algunos reclusos garífunas del Centro Penal de Tela, fue discriminatoria y en perjuicio del señor López Álvarez.

Las anteriores consideraciones llevaron a la Corte a concluir que el Estado era responsable por la violación al derecho a la libertad de pensamiento y de expresión y al derecho de igualdad ante la ley, así como por el incumplimiento de la obligación general de respetar y garantizar los derechos y libertades, en perjuicio de Alfredo López Álvarez. ${ }^{146}$

En el Caso Chitay Nech, el desplazamiento de sus familiares fuera de su comunidad provocó una ruptura con su identidad cultural, afectando el vínculo con sus familiares, su idioma y su pasado ancestral. ${ }^{147}$ En consecuencia, conforme a su jurisprudencia constante en materia indígena, la Corte IDH consideró que el desplazamiento forzado de los pueblos indígenas o de sus integrantes los puede colocar en una situación de especial vulnerabilidad, que "[p]or sus secuelas destructivas sobre el tejido étnico y cultural... genera un claro riesgo de extinción, cultural o físico, de los pueblos indígenas". Por tanto, consideró indispensable que los Estados adopten medidas específicas de protección, considerando las particularidades propias de los pueblos indígenas, así como su derecho consuetudinario, valores, usos y costumbres, para prevenir y revertir los efectos de tal situación. ${ }^{148}$

145 Ibidem, párr. 172.

146 Ibidem, párr. 174.

147 Corte IDH, Caso Chitay Nech y otros vs. Guatemala. Excepciones Preliminares, Fondo, Reparaciones y Costas. Sentencia del 25 de mayo de 2010. Serie C, No. 212, párr. 146.

148 Ibidem, párr. 147. 
Finalmente, un tema que no debe pasar desapercibido es el relativo al derecho a la identidad cultural. El único caso en el cual la Corte IDH ha expresado la vulneración de manera autónoma a este derecho (como ratio decidendi) es en el Caso Pueblo Indígena Kichwa de Sarayaku vs. Ecuador, en cuya sentencia destacó que:

...bajo el principio de no discriminación establecido en el artículo 1.1 de la Convención, el reconocimiento del derecho a la identidad cultural es ingrediente y vía de interpretación transversal para concebir, respetar y garantizar el goce y ejercicio de los derechos humanos de los pueblos y comunidades indígenas protegidos por la Convención y, según el artículo 29.b) de la misma, también por los ordenamientos jurídicos internos. ${ }^{149}$

La Corte IDH consideró que dos instrumentos internacionales tienen particular relevancia en el reconocimiento del derecho a la identidad cultural de los pueblos indígenas y tribales: el Convenio No. 169 de la OIT, sobre pueblos indígenas y tribales, y la Declaración de las Naciones Unidas sobre los Derechos de los Pueblos Indígenas, ${ }^{150}$ y agregó que:

...el derecho a la identidad cultural es un derecho fundamental y de naturaleza colectiva de las comunidades indígenas, que debe ser respetado en una sociedad multicultural, pluralista y democrática. Esto implica la obligación de los Estados de garantizar a los pueblos indígenas que sean debidamente consultados sobre asuntos que inciden o pueden incidir en su vida cultural y social, de acuerdo con sus valores, usos, costumbres

149 Corte IDH, Caso Pueblo Indígena Kichwa de Sarayaku vs. Ecuador. Fondo y reparaciones. Sentencia del 27 de junio de 2012. Serie C, No. 245, párr. 213. 150 Ibidem, párr. 215. 
y formas de organización. En el mismo sentido, el Convenio No. 169 de la OIT reconoce las aspiraciones de los Pueblos indígenas a "asumir el control de sus propias instituciones y formas de vida y de su desarrollo económico y a mantener y fortalecer sus identidades, lenguas y religiones, dentro del marco de los Estados en que viven. ${ }^{151}$

\section{MEDIDAS DE PROTECCIÓN}

Finalmente, es importante destacar que el Sistema Interamericano ha dado especial importancia a las medidas de protección, tendientes a responder a situaciones que prima facie sean de gravedad. En específico, la Comisión IDH ha dictado numerosas medidas cautelares otorgadas a favor de comunidades indí-

151 Llama la atención en este caso las referencias que se hacen respecto del valor simbólico que tienen ciertos elementos del territorio indígena con relación a la afectación de la integridad cultural, 219. Dada la importancia que tienen los sitios de valor simbólico para la identidad cultural del pueblo Sarayaku y su cosmovisión, como sujeto colectivo, varios de los testimonios y peritajes producidos durante el proceso indican el fuerte lazo que existe entre los elementos de la naturaleza y de la cultura, por un lado, y las dimensiones del ser de cada integrante del pueblo, por otro. Lo anterior denota también las profundas afectaciones a las relaciones sociales y espirituales que los integrantes de la comunidad pueden tener con los diferentes elementos de la naturaleza que los rodea cuando son destruidos o menoscabados, 220. La Corte considera que la falta de consulta al pueblo Sarayaku afectó su identidad cultural, por lo que no cabe duda que la intervención y destrucción de su patrimonio cultural implica una falta grave al respeto debido a su identidad social y cultural, a sus costumbres, tradiciones, cosmovisión, y a su modo de vivir, produciendo, naturalmente, gran preocupación, tristeza y sufrimiento entre los mismos. Corte IDH, Caso Pueblo Indígena Kichwa de Sarayaku vs. Ecuador. Fondo y Reparaciones. Sentencia del 27 de junio de 2012. Serie C, No. 245, párr. 219. 
genas ${ }^{152}$ en situaciones de desplazamiento, ${ }^{153}$ de desalojo, ${ }^{154} \mathrm{de}$ conflicto armado, ${ }^{155}$ de aislamiento voluntario, ${ }^{156}$ o afectadas por proyectos en alegados territorios indígenas. ${ }^{157}$ Asimismo, ha ordenado la protección de líderes indígenas. ${ }^{158}$ Por su parte, la Corte $\mathrm{IDH}$ ha dictado medidas de protección a las comunidades de Colotenango, Plan de Sánchez, del Pueblo Indígena Kankuamo, de la Comunidad Mayagna (Sumo) Awas Tingni, del Pueblo Indígena Sarayaku y a integrantes de la comunidad indígena Choréachi. ${ }^{159}$

152 Pueden verse todas las medidas cautelares en el siguiente enlace: http://www.oas.org/es/cidh/indigenas/proteccion/cautelares.asp.

153 Véanse, por ejemplo, las medidas cautelares MC 197-10 y MC 60/12 de San Juan Copala, del 2010 y 2012 (México).

154 Véanse, por ejemplo, las medidas cautelares MC21/11, de las catorce comunidades maya Q'echi, del 2011 (Guatemala).

155 Véanse, por ejemplo, las medidas cautelares MC-61/11 a favor del pueblo Awá, de 2011 (Colombia), y medidas cautelares MC255/11 a favor del pueblo Nasa del 2011 (Colombia).

156 Véanse, por ejemplo, las medidas cautelares a favor del pueblo Tagaeri/Taromenani (Ecuador), en http://www.oas.org/es/cidh/indigenas/proteccion/ cautelares.asp.

157 Véanse, por ejemplo, las medidas cautelares a favor de las comunidades Ngöbe (Panamá), Bello Monte (Brasil), y Mina Marlin (Guatemala), en http://www.oas.org/es/cidh/indigenas/proteccion/cautelares.asp.

158 Véanse, por ejemplo, las siguientes medidas cautelares: Dirigentes del Consejo Regional Indígena del Cauca (CRIC) y sus asesores (Colombia), Aura Lolita Chávez Ixcaquic (Guatemala), Lideresas del pueblo indígena wayúu (CoIombia), Leonidas Iza (Ecuador), Rosalina Tuyuc (Guatemala), Zenilda Maria de Araujo y Marcos Luidson de Araujo (Cacique Marquinhos), líderes indígenas del pueblo Xucuru (Brasil), Aldo González Rojas y Melina Hernández Sosa (México), Asociación Nacional de Mujeres Campesinas e Indígenas de Colombia (Anmucic) (Colombia), entre otras.

159 Véanse las resoluciones de la Corte con relación al asunto de la comunidad de Colotenango respecto de Guatemala, solicitadas en 1994 y levantadas en 2007; Resoluciones respecto del caso de la comunidad Mayagna (Sumo) Awas Tingni respecto de Nicaragua, otorgadas en 2002 y levantadas en 2007; Resolución de la Masacre Plan de Sánchez (Salvador Jerónimo y otros) vs. Guatemala, otorgadas en 2004 y levantadas en 2005; Resoluciones del Asunto Pueblo Indígena Kankuamo respecto de Colombia, otorgadas en 2004 y levantadas en 2011; Resoluciones del Pueblo Indígena Sarayaku respecto de 
Como se ha visto, si bien el desarrollo jurídico de los derechos de los pueblos indígenas continúa, no se puede negar que la jurisprudencia que los órganos del Sistema Interamericano han ido desarrollando en el reconocimiento de los derechos de los pueblos indígenas ha permitido dar importantes pasos en la materia, no sólo a nivel conceptual, sino en conseguir efectos concretos para ellos.

Ecuador, solicitadas en 2004 y vigentes a la fecha; Asunto Serech and Saquic respecto de Guatemala, solicitadas en 1996 y levantadas en 1997. Véase en similar sentido: Corte IDH, Asunto Integrantes de la Comunidad Indígena de Choréachi respecto de México. Solicitud de medidas provisionales. Resolución de la Corte Interamericana de Derechos Humanos de 25 de marzo de 2017. 


\section{SISTEMA AFRICANO DE DERECHOS HUMANOS}

Sistema Africano de Derechos Humanos, el más joven
de los sistemas regionales de derechos humanos (1981),
reconoce la naturaleza individual y colectiva de protección, es decir, de las personas y de los pueblos. Su marco jurídico principal es la Carta Africana de los Derechos Humanos y de los Pueblos, o Carta de Banjul.

Es importante destacar tres casos en el Sistema Africano: el Caso Endorois vs. Kenia y el Caso Ogoni vs. Nigeria, resueltos por la Comisión Africana de Derechos Humanos, y el Caso Ogiek vs. Kenia, resuelto por la Corte Africana de Derechos Humanos y de los Pueblos.

\section{CASO ENDOROIS VS. KENIA}

En este caso, la Comisión Africana de Derechos Humanos determinó que la falta de acceso al lago Bogoria —que el pueblo Endorois siempre había utilizado como sitio sagrado para ceremonias religiosas y culturales, como bodas, funerales e iniciaciones tradicionales - no permitía al pueblo ejercer su derecho a la vida cultural, pues se sentían desconectados de sus tierras y de sus ancestros. ${ }^{160}$ En el caso se alegó la violación de los derechos de

160 ACHPR, Centre for Minority Rights Development (Kenya) and Minority Rights Group International on Behalf of Endorois Welfare Council vs. Kenya, 276/2003, párr. 108. 
libertad de conciencia y religión (artículo 80.), de propiedad (artículo 14), a participar en la vida cultural (artículo 17), de disposición libre de los recursos naturales (artículo 21) y al desarrollo (artículo 22).

Una cuestión controvertida era si la parte involucrada era una comunidad indígena. ${ }^{161}$ La Comisión africana aclaró los conceptos de pueblos, pueblos indígenas y comunidades, y explicó que no existe una definición universal sobre pueblos indígenas, dada la diversidad de culturas, historia o circunstancias actuales, pues las relaciones entre los pueblos indígenas y los grupos dominantes o la corriente principal de la sociedad, varía de país en país. Añadió que lo mismo puede decirse del término pueblos. ${ }^{162}$

En el caso, la Comisión africana consideró que los Endorois eran un pueblo indígena y expresó que algunos grupos marginados de África eran excluidos de los paradigmas de desarrollo y, en muchos casos, eran víctimas de políticas públicas generales de desarrollo. ${ }^{163}$ Así, enfatizó que los pueblos indígenas se convierten en grupos marginados en su propio país y que necesitan del reconocimiento y la protección de sus derechos humanos básicos y de sus libertades fundamentales. ${ }^{164}$

En segundo lugar, la Comisión estimó que la Carta Africana es un documento innovador, pues enfatiza los derechos humanos de los pueblos" y se aparta sustancialmente de las formulaciones cerradas de otros instrumentos internacionales regionales y universales de protección de derechos humanos. Asimismo, consideró que el término indígena no crea un grupo especial de personas titulares de derechos, sino que se acuña como un concepto para enfrentar las injusticias históricas y actuales, así

\footnotetext{
161 Ibidem, párrs. 144 y 145.

162 Ibidem, párr. 147.

163 Ibidem, párr. 148.

164 Idem.
} 
como a las desigualdades. Finalmente, el concepto indígena, según la Comisión africana, se encuentra estrechamente vinculado con los derechos colectivos o de grupos. ${ }^{165}$

En relación con lo anterior, y en tercer lugar, la Comisión africana externó que los artículos 20 a 24 (derecho de autodeterminación, disposición de recursos naturales, derecho al desarrollo y derecho a un entorno favorable) de la Carta de Banjul, reconocen una serie de derechos para los pueblos, como entes colectivos.

En este sentido, la Comisión refirió, a través de su Grupo de Trabajo de Expertos sobre Poblaciones/Comunidades Indígenas, que existen cinco criterios para identificar a los pueblos indígenas: a) la ocupación y uso de un determinado territorio; b) la perpetuación voluntaria de la distinción cultural; c) la autoidentificación como una colectividad distinta, así como el reconocimiento por otros grupos; d) una experiencia de sometimiento, marginación, desposesión, exclusión o discriminación, y e) una característica clave de la mayoría de los diferentes grupos de antiguos cazadores/recolectores es que la supervivencia de su modo de vida particular depende del acceso y los derechos a sus tierras tradicionales y los recursos naturales. ${ }^{166}$

De este modo, concluyó que, si bien existen diferentes tendencias emergentes que intentan definir "a los pueblos indígenas", todas ellas tienen en común que consideran los vínculos entre los pueblos, la tierra, la cultura y que ese grupo expresa su deseo por ser identificado como un pueblo, o tener la conciencia de ser un pueblo diferente a los demás. ${ }^{167}$

165 Ibidem, párr. 149.

166 Ibidem, párr. 150.

167 ACHPR, Centre for Minority Rights Development (Kenya) and Minority Rights Group International on behalf of Endorois Welfare Council vs. Kenya, 276/2003, párr. 151. 
Adicionalmente, la Comisión se valió de otras fuentes auxiliares de derecho internacional para establecer la relación de los pueblos con las tierras. ${ }^{168}$ Llama particularmente la atención el diálogo de la Comisión africana con la jurisprudencia interamericana, cuando, además de la relación sagrada con la tierra, destacó la autoidentificación como otro criterio importante para la determinación de los pueblos indígenas. En ese sentido, puntualizó que:

...la Corte IDH se ha ocupado de casos de auto identificación donde las comunidades afro descendientes estaban viviendo de manera colectiva y tenían dos o tres siglos desarrollando un vínculo ancestral con sus tierras... dependiendo su modo de vida en gran medida del uso tradicional de las tierras, al igual que su supervivencia cultural y espiritual debido a la existencia de tumbas ancestrales en estas tierras... ${ }^{169}$ destacando dos decisiones pertinentes [:] Moiwana y Saramaka [ambas contra Suriname]..$^{170}$

168 Artículo 61. La Comisión también tomará en consideración, como medidas subsidiarias para determinar los principios del derecho aplicables, otros convenios generales o especiales que establezcan normas expresamente reconocidas por los Estados miembros de la Organización para la Unidad Africana, prácticas africanas que concuerdan con las normas internacionales relativas a los derechos humanos y de los pueblos, costumbres generalmente aceptadas como normas, principios generales del derecho reconocidos por los Estados africanos, así como precedentes legales y creencias. Particularmente refirió a: Grupo de Trabajo sobre Poblaciones Indígenas, la Organización Internacional del Trabajo y la Relator Especial de Naciones Unidas sobre Pueblos Indígenas. ACHPR, Centre for Minority Rights Development (Kenya) and Minority Rights Group International on Behalf of Endorois Welfare Council vs. Kenya, 276/2003, párrs. 152- 156.

169 ACHPR, Centre for Minority Rights Development (Kenya) and Minority Rights Group International on Behalf of Endorois Welfare Council vs. Kenya, 276/2003, párr. 158.

170 Ibidem, párrs. 159-162. 
Como apuntamos, las violaciones alegadas en el caso se relacionaban con los derechos indígenas de preservación de su identidad a través de la identificación con sus tierras ancestrales. ${ }^{171}$ Con base en la argumentación referida, la Comisión africana concluyó que los Endorois son una comunidad indígena que comparte una historia común, una cultura y religión, por lo que podían beneficiarse de los derechos colectivos como pueblo.

Además, en relación con el derecho a la libertad religiosa (artículo 8o.), la Comisión africana estableció que la religión se encuentra, a menudo, vinculada con la tierra, las creencias y las prácticas culturales, y que la libertad de culto y de llevar a cabo actos ceremoniales están en el centro de la libertad de religión. Destacó que las prácticas culturales y religiosas de los Endorois son de vital importancia, y que el lago Bogoria es el hogar espiritual de todos los vivos y muertos del pueblo. ${ }^{172}$ Por tanto, la Comisión africana concluyó que las prácticas ceremoniales y creencias espirituales de los Endorois constituyen una religión, y limitar el acceso al lago — argumentando interés económicofue una violación a este derecho. ${ }^{173}$

Con lo referente al derecho a la propiedad - tras analizar diversos instrumentos regionales de derechos humanos y jurisprudencia (europea, universal e interamericana) — la Comisión concluyó lo siguiente:

(1) la posesión tradicional de la tierra por los indígenas tiene efecto equivalente a la de título de pleno dominio que otorga el Estado; (2) la posesión tradicional otorga a los indígenas para eximir el reconocimiento oficial y el registro de títulos de propiedad; (3) los miembros de los pueblos indígenas que han abandonado sus tierras tradicionales por la fuerza o

171 Ibidem, párr. 162.

172 Ibidem, párr. 166.

173 Ibidem, párrs. 168 y ss. 
perdido la posesión del mismo, mantienen los derechos de propiedad de los mismos, a pesar de carecer de título legal, a unos que las tierras hayan sido transferida legalmente a terceros de buena fe; y (4) los miembros de los pueblos indígenas que involuntariamente han pedido la posesión de sus tierras y éstas han sido transferidas legítimamente a terceros inocentes, tienen el derecho de recuperarlas o a obtener otras tierras de igual extensión y calidad. En consecuencia, la posesión no es una condición necesaria para la existencia de los derechos de restitución de tierras indígenas. ${ }^{174}$

En cuanto a los procedimientos de consulta, destacó que existen dos elementos adicionales que se desprenden de la expresión "de acuerdo con la ley", y se refieren a los requisitos de la consulta y la compensación. En cuanto a la primera, estableció que "el umbral es especialmente estricto en favor de los pueblos indígenas, ya que también requiere que se conceda el consentimiento. El incumplimiento de las obligaciones de consulta y la solicitud del consentimiento -o de indemnizaciónen última instancia, resulta en una violación del derecho de propiedad". ${ }^{175}$

La Comisión consideró que el territorio Endorois había sido invadido de manera desproporcionada sin justificación de necesidad pública y que se contraponía a los estándares nacionales e internacionales. En consecuencia, estimó violados los derechos de religión y propiedad, reconocidos en los artículos 8o. y 14 de la Carta Banjul, ${ }^{176}$ así como al derecho a ejercer las prácticas culturales dentro del territorio (artículos 17.2 y 17.3), y el derecho a disponer de los recursos dentro de dicho territorio y que afectaban su supervivencia como pueblo (artículo 21). Finalmente,

174 Ibidem, párr. 209.

175 Ibidem, párrs. 225 y 226.

176 Ibidem, párr. 238. 
la Comisión estimó que el Estado no había propiciado condiciones necesarias para el desarrollo del pueblo Endorois.

\section{CASO OGONI VS. NIGERIA}

En el caso, los demandantes alegaban que el gobierno militar de Nigeria había participado directamente en la producción de petróleo a través de la empresa petrolera estatal, la Compañía Nacional de Petróleo de Nigeria, como el accionista mayoritario de una asociación con la Shell Petroleum Deveploment Corporation, y que estas operaciones habían causado degradación ambiental y problemas de salud derivados de la contaminación en el pueblo Ogoni. ${ }^{177}$ Por ello, los demandantes alegaron la violación al derecho a la salud y al derecho al medio ambiente sano (artículos 16 y 24). ${ }^{178}$

La Comisión africana consideró que tales derechos reconocen la importancia de un entorno limpio y seguro, estrechamente ligado a los derechos económicos y sociales en la medida en que el entorno afecta la calidad de vida y la seguridad de una persona. ${ }^{179}$ Por tanto, para cumplir con esas obligaciones, el Estado debe incluir una orden, o por lo menos un seguimiento científico independiente de los entornos amenazados, lo que requiere dar a conocer los estudios de impacto ambiental y social antes de cualquier desarrollo industrial importante, y debe, asimismo, darles un seguimiento adecuado e informar a las comunidades expuestas a materiales y actividades peligrosas. Además, debe propiciar oportunidades significativas a las

177 ACHPR, The Social and Economic Rights Action Center and the Center for Economic and Social Rights vs. Nigeria, Communications No. 155/96, párr. 1.

178 Ibidem, párr. 50.

179 Ibidem, párr. 51. 
personas, para que sean escuchadas y puedan participar en las decisiones de desarrollo que afecten a sus comunidades. ${ }^{180}$

Adicionalmente, se alegó la violación del derecho a la libre disposición de sus riquezas y recursos naturales (artículo 21), pues al estar involucrado en la producción de petróleo, el Estado debió supervisar y regular las operaciones de las compañías petroleras. Además, no se incluyó a las comunidades Ogoni en las decisiones que afectaron el desarrollo de la región. ${ }^{181}$ Por otro lado, se alegó la violación del derecho a la vivienda —no reconocido en la Carta Africana, pero que, según los demandantes, estaba implícito en los artículos 14, 16 y 18 de la Carta de Banjul— ${ }^{182}$ y el derecho a la alimentación, tampoco reconocido en la Carta Africana, pero que consideraban implícito en los artículos 4o., 16 y 22 de la de Banjul. ${ }^{183}$ La Comisión africana compartió esa interpretación.

\section{CASO OGIEK VS. KeNIA}

La Corte Africana de Derechos Humanos se pronunció en el Caso Ogiek vs. Kenia, sobre las violaciones a los derechos relacionadas con la comunidad indígena Ogiek del Bosque Mau, la cual, por un decreto del gobierno (a través del Servicio Forestal de Kenia), debía desalojar dicho bosque en treinta días. Según los peticionarios, el aviso de desalojo fue emitido porque se trataba de una zona reservada para la captación de agua.

En lo concerniente a si los Ogiek constituían un pueblo indígena, la Corte africana expresó que el concepto de población

\footnotetext{
180 Ibidem, párr. 53.

181 Ibidem, párr. 55.

182 Ibidem, párrs. 59-63.

183 Ibidem, párrs. 64-67.
} 
indígena no se encuentra definido en la Carta Africana, y, además, no existe una definición universalmente aceptada en otros instrumentos internacionales de derechos humanos. ${ }^{184}$ Así, la Corte destacó que algunos de los factores relevantes a considerar eran la presencia en el tiempo sobre la ocupación y uso de un territorio específico; una perpetuación voluntaria del carácter distintivo de la cultura (como la lengua, la organización social, la religión y los valores espirituales, los modos de producción, las leyes y las instituciones); la autoidentificación, así como el reconocimiento por parte de otros grupos, o por las autoridades del Estado, de que son una colectividad distinta; y una experiencia de sometimiento, marginación, desposesión, exclusión o discriminación, independientemente de que estas condiciones persistan. ${ }^{185}$ La Corte constató que los Ogiek cumplían con todos los requisitos señalados, ${ }^{186}$ por lo que se les reconoció como un pueblo indígena que forma parte del pueblo keniano, con un estatus particular, merecedores de una protección especial derivada de su particular situación de vulnerabilidad. ${ }^{187}$

En relación con el derecho de propiedad (artículo 14 de la Carta de Banjul), el tribunal africano expresó que la disposición puede ser aplicada tanto de manera individual como colectiva, ${ }^{188}$ y consideró que, en su concepción clásica, el derecho de propiedad suele referirse a tres elementos: el derecho a usar lo que es objeto del derecho, el derecho a disfrutar el fruto y el derecho de disponer de la cosa, es decir, el derecho de transferir. ${ }^{189}$ Con

184 ACoHPR, African Commission on Human and People's Rights (Ogiek) vs. Kenya, Application No. 006/2012. Sentencia del 26 de mayo de 2017, párr. 105.

185 Ibidem, párr. 107.

186 Ibidem, párrs. 109-111.

187 Ibidem, párr. 112.

188 Ibidem, párr. 123.

189 Ibidem, párr. 124. 
independencia de lo anterior, la Corte estimó que, en el caso de comunidades indígenas, la lectura debería hacerse de acuerdo con las disposiciones de la Declaración de Naciones Unidas sobre los Derechos de los Pueblos Indígenas, y en especial del artículo 26. ${ }^{190}$

En ese sentido, la Corte africana consideró que, en el caso, la parte demandada no discutía que la comunidad Ogiek había ocupado las tierras desde tiempos inmemorables, por lo que sus miembros tenían derecho a ocupar sus tierras ancestrales, así como al uso y disfrute de dichas tierras; ${ }^{: 191}$ sin embargo, también señaló que el artículo 14 prevé la posibilidad de restringir el derecho de propiedad, incluida la tierra, siempre que tal restricción sea de interés público, y que también sea necesaria y proporcional. ${ }^{192}$

En ese caso en concreto, la Corte constató que la justificación para el desalojo de los miembros de la comunidad había sido la preservación del ecosistema natural. No obstante, el Estado no aportó ninguna prueba de que la presencia continua de los Ogiek en la zona fuera la causa principal del agotamiento del medio natural. Por el contrario, la Corte africana demostró que la degradación ambiental se debía a las invasiones por parte de otros grupos y a las concesiones de tala de madera. Así, el

190 Ibidem, párr. 125. El artículo 26 de la Declaración Universal sobre Derechos de los Pueblos Indígenas establece: 1. Los pueblos indígenas tienen derecho a las tierras, territorios y recursos que tradicionalmente han poseído, ocupado o utilizado o adquirido. 2. Los pueblos indígenas tienen derecho a poseer, utilizar, desarrollar y controlar las tierras, territorios y recursos que poseen en razón de la propiedad tradicional u otro tipo tradicional de ocupación o utilización, así como aquellos que hayan adquirido de otra forma. 3. Los Estados asegurarán el reconocimiento y protección jurídicos de esas tierras, territorios y recursos. Dicho reconocimiento respetará debidamente las costumbres, las tradiciones y los sistemas de tenencia de la tierra de los pueblos indígenas de que se trate.

191 Ibidem, párr. 128.

192 Ibidem, párr. 129. 
desalojo de la población Ogiek del bosque Mau - y la continua negación a que accedieran de nuevo - no podía ser necesaria ni proporcional para lograr la pretendida justificación de la preservación del ecosistema natural. ${ }^{193}$

Derivado de la negación del uso y disfrute de la propiedad colectiva indígena, la Corte determinó que se habían violado el derecho a la religión (artículo 80.), ${ }^{194}$ el derecho a la vida cultural (artículos 17.2 y 17.3), ${ }^{195}$ el derecho a disfrutar de las riquezas (artículo 21) ${ }^{196}$ y el derecho al desarrollo (artículo 22). ${ }^{197}$

Para concluir, es importante estar atentos a la sentencia de reparaciones del caso que emitirá el tribunal africano, pues tal como lo destaca la decisión analizada, la Corte decidió que se pronunciaría "sobre cualquier otra forma de reparación en una decisión separada, teniendo en cuenta las comunicaciones adicionales de las Partes". ${ }^{198}$

193 Ibidem, párr. 130.

194 Ibidem, párr. 169.

195 Ibidem, párr. 190.

196 Ibidem, párr. 201.

197 Ibidem, párr. 211.

198 Ibidem, párr. 223. 
Este libro forma parte del acervo de la Biblioteca Jurídica Virtual del Instituto de Investigaciones Jurídicas de la UNAM

\section{SISTEMA EUROPEO DE DERECHOS HUMANOS}

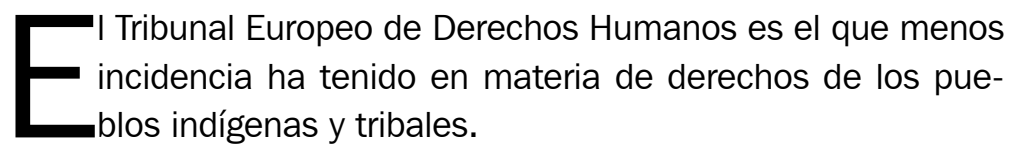

El caso más significativo es Handölsdalen Sami Village y otros vs. Suecia (2010), ${ }^{199}$ relacionado con las Comunidades Sami del norte de Europa, criadoras de renos. ${ }^{200}$ En el caso concreto, un grupo de propietarios iniciaron procesos internos contra cinco pueblos Sami, pues consideraban que éstos no tenían derecho de pastoreo de renos en sus tierras sin un contrato válido celebrado entre el propietario y el pueblo. ${ }^{201}$ Los Sami alegaron la

199 ECoHR, Application No. 27033/95, Caso Könkämä y otros 38 miembros de la Villa Saami vs. Suecia, Admisibilidad del 25 de noviembre de 1996.

200 Los Saami o Sami desde la antigüedad habitaban las regiones del norte de Escandinavia y la Península de Kola. Originalmente vivían de la caza, la pesca y la recolección, posteriormente, sus actividades cambiaron, y ejercían principalmente en la cría de renos. Su uso histórico de la tierra ha dado lugar a un derecho especial a bienes raíces, el derecho de pastoreo de renos (Renskötselrätten). Dicha actividad estaba regulada en Suecia por la Ley sobre la Cría del Reno (Rennäringslagen, 1971: 437), que comprendía el derecho de uso de la tierra y el agua para el propio sustento de los Sami y la de sus renos. Y tal derecho sólo podía ser ejercido por los miembros de un pueblo Sami. La zona de cría de renos comprendía aproximadamente un tercio de la superficie de Suecia y todos los años se divide la tierra de la tierra de pastoreo de invierno. En ciertas partes del país, los límites de la zona de pastoreo son controvertidos y no se han definido en las leyes, especialmente en lo que se refiere a la tierra de pasto de invierno. TEDH, Caso de la Villa Sami Handölsdalen vs. Suecia, Application No. 39013/04, Sentencia del 30 de marzo de 2010, párr. 7.

201 TEDH, Caso de la Villa Sami Handölsdalen vs. Suecia, Application No. 39013/04. Sentencia del 30 de marzo de 2010, párr. 6. 
violación de los derechos de defensa y de plazo razonable (artículo 6o. del Convenio Europeo de Derechos Humanos), por los altos costos de los procedimientos jurisdiccionales que se traducían en un acceso inefectivo a los tribunales para los pueblos que criaban renos y por la duración excesiva de los procedimientos. ${ }^{202}$

Respecto del primer alegato, el tribunal europeo consideró que si bien los propietarios de tierras tenían mayores recursos financieros que los pueblos Sami, la complejidad del caso había contribuido de manera significativa a los costos que dichos pueblos tuvieron que soportar. Por tanto, examinado el proceso en su conjunto, consideró que los demandantes tuvieron una oportunidad razonable de presentar su caso de manera efectiva ante los tribunales nacionales y que no había una desigualdad de armas, por lo que no existía una violación al derecho de defensa (artículo 6.1). ${ }^{203}$

En cuanto al segundo alegato - duración excesiva de los procedimientos- el tribunal observó que el proceso duró trece años y siete meses, del 20 de septiembre de 1990, cuando se inició la primera acción de sentencia declarativa ante el tribunal de distrito, al 29 de abril de 2004, cuando el tribunal supremo denegó la autorización de apelar. Bajo los criterios establecidos en la jurisprudencia, la Corte europea consideró que la duración del procedimiento había sido excesiva y que no había cumplido en un tiempo razonable, por lo que constituía una violación al artículo 6.1 en este extremo. ${ }^{204}$

202 Ibidem, párrs. 45-47.

203 Ibidem, párr. 59.

204 TEDH, Caso de la Villa Sami Handölsdalen vs. Suecia, Application No. 39013/04, Sentencia del 30 de marzo de 2010, párrs. 62, 66 y 67 . Y señaló que: “65. La Corte observó, además, que hubo demoras innecesarias, sobre todo ante el Tribunal Supremo, lo que contribuyó a la duración total. Así le había tomado al Tribunal Supremo dos años y medio para decidir, el 18 de 
Este libro forma parte del acervo de la Biblioteca Jurídica Virtual del Instituto de Investigaciones Jurídicas de la UNAM

En apreciación de la jueza Ineta Ziemele, el tribunal europeo debió declarar también la violación al acceso efectivo a los tribunales, pues al tratarse de un pueblo indígena, existía un desbalance con los propietarios suecos, para lo cual se debieron tomar en cuenta los avances de los derechos de los pueblos indígenas en materia internacional, como el Convenio 169 de la OIT y la Declaración de Naciones Unidas sobre los Derechos de los Pueblos Indígenas. ${ }^{205}$

En relación con los procesos civiles de tribunales nacionales, los pueblos Sami debían producir documentales y dar pruebas de su ocupación desde tiempos inmemoriales, ya que el título de los propietarios privados de la tierra se presumía válido, ${ }^{206}$ y la jueza destacó:

En mi opinión, en la consideración de los derechos de los pueblos indígenas, la Cámara [del Tribunal Europeo] basó su razonamiento en dos premisas falsas. En primer lugar, [que era] aceptado como indiscutible el hecho de que los demandantes en los procesos internos tenían título válido sobre la tierra. En segundo lugar, se acept[ó] que las normas sobre la carga de la prueba, según lo establecido en Suecia en el antiguo Código de Tierras de 1734, es decir, mucho antes

febrero de 1999, que los demandantes no tenían derecho a apelar en lo que refería a la cuestión de si en los procedimientos que carecían de capacidad de actuar como parte. Durante ese periodo se suspendieron los procedimientos ante el Tribunal de Apelación. El Tribunal Supremo también pasó cerca de dos años antes de decidir, el 29 de abril de 2004, el denegar el recurso en lo que respecta al fondo del asunto. Por otra parte, durante la mayor parte del año 2000 no hubo mucha actividad por parte de la corte de apelaciones". TEDH, Caso de la Villa Sami Handölsdalen vs. Suecia, Application No. 39013/04. Sentencia del 30 de marzo de 2010, párr. 65.

205 Voto de la Jueza Ziemele al Caso de la Villa Sami Handölsdalen vs. Suecia, Application No. 39013/04. Sentencia del 30 de marzo de 2010, párrs. $1-3$.

206 Voto de la Jueza Ziemele al Caso de la Villa Sami Handölsdalen vs. Suecia, Application No. 39013/04. Sentencia del 30 de marzo de 2010, párr. 4. 
de que el reconocimiento de los pueblos indígenas surgiera, eran perfectamente capaces de regir la situación. Este enfoque excluye consideraciones relacionadas con el contexto específico de la situación y los derechos de los pueblos indígenas en la medida en que podrían ser relevantes al tema de acceso efectivo a los tribunales.

En las circunstancias de este caso, y teniendo en cuenta la carga de la prueba que los Samis tenían que satisfacer, así como el número de años en los tribunales nacionales, no es de extrañar que los costos legales hubieran llegado a tal nivel... esto equivalía a una discriminación de facto [por lo que] desde la perspectiva de la Corte esto deb[ió] haber sido visto como un caso de acceso ineficaz a las Cortes, sobre todo porque una de las partes parece haber sido, obviamente en desventaja. ${ }^{207}$

La jueza Ziemele concluyó que, al equiparar las partes como litigantes individuales y no pertenecientes a un grupo en situación de vulnerabilidad, el tribunal europeo ignoró el contexto de las comunidades Sami, y en consecuencia, los derechos y las circunstancias particulares que tenían como pueblos indígenas. ${ }^{208}$

207 Ibidem, párrs. 5 y 8.

208 Ibidem, párrs. 9 y 10. 
Este libro forma parte del acervo de la Biblioteca Jurídica Virtual del Instituto de Investigaciones Jurídicas de la UNAM

\section{SISTEMA UNIVERSAL DE DERECHOS HUMANOS ${ }^{209}$}

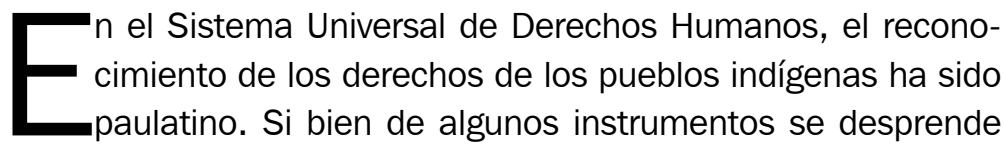
el principio de igualdad y no discriminación - entre otras, por razón de raza-, ${ }^{210}$ la prohibición del genocidio ${ }^{211}$ o el reconoci-

209 La enumeración de documentos que se hace en este capítulo no es limitativa, sino que sólo se mencionan los instrumentos que se consideran más relevantes para el presente estudio. Asimismo, se consideran otros instrumentos internacionales que contemplan disposiciones que protegen derechos de los pueblos indígenas y tribales, tales como: Convención sobre los Derechos del Niño, Convención sobre la Eliminación de Todas las Formas de Discriminación contra la Mujer, Convención sobre la Eliminación de Todas Formas de Discriminación Racial, Convención Internacional sobre la Protección de todos los Trabajadores Migratorios y de sus Familiares, Convenio Sobre la Diversidad Biológica, Declaración sobre la Raza y los Prejuicios Raciales, Declaración sobre los Derechos de las personas pertenecientes a Minorías Nacionales o Étnicas, Religiosas y Lingüísticas, Declaración de Viena y Programa de Acción, Declaración del Milenio de las Naciones Unidas y Declaración Universal de la UNESCO sobre la Diversidad Cultural.

210 ONU, Carta de las Naciones Unidas de 1945, Art. 55. Declaración Universal de los Derechos Humanos Pacto Internacional de los Derechos Civiles y Políticos (PIDCP) y el Pacto Internacional de los Derechos Económicos, Sociales y Culturales (PIDESC) (1966).

211 ONU, Convención para la Prevención y Sanción del Delito de Genocidio.

Algunas organizaciones y pueblos indígenas han invocado esta convención alegando ser víctimas tanto de actos de genocidio como de lo que doctrinalmente se ha denominado genocidio cultural o etnocidio. Ninguna ha tenido respuesta favorable en el seno de la ONU, salvo por referencias de los Relatores Especiales de los Derechos de los Pueblos Indígenas. Cfr. ONU, Consejo Económico y Social, Cuestiones Indígenas, Derechos Humanos y Cuestiones Indígenas, Informe del Relator Especial sobre la Situación de los Derechos 


\section{miento de las minorías étnicas, ${ }^{212}$ no es sino hasta los convenios de la Organización Internacional del Trabajo (OIT) que se hace un análisis específico relacionado a los pueblos indígenas; ${ }^{213}$ y es}

Humanos y las Libertades Fundamentales de los Indígenas, Sr. Rodolfo Stavenhagen. Adición Misión a Colombia, E/CN.4/2005/88/Add.2, 10 de noviembre de 2004, párr. 115.

212 Véase, por ejemplo, artículo 27 del Pacto Internacional de Derechos Civiles y Políticos: “En los Estados en que existan minorías étnicas, religiosas o lingüísticas, no se negará a las personas que pertenezcan a dichas minorías el derecho que les corresponde, en común con los demás miembros de su grupo, a tener su propia vida cultural, a profesar y practicar su propia religión y a emplear su propio idioma. Al respecto O'Donnel señala: “La ambigüedad con que se usa la palabra no puede operar en el sentido de no incluir a los pueblos indígenas, sobre todo porque en él no hay referencia alguna de donde se pueda desprender una interpretación en ese sentido, sino por el contrario, la explicación presenta elementos inherentes a los pueblos indígenas. Excluir a los pueblos indígenas del contenido de los Pactos, puede constituir prácticas de discriminación prohibidas por el propio orden internacional”. Cfr. O’Donnell, Daniel, Derecho Internacional de los Derechos Humanos, Oficina del Alto Comisionado de las Naciones Unidas para los Derechos Humanos México-Tecnológico de Monterrey, Bogotá, abril de 2004, pp. 851- 854.

Por su parte, EI PIDESC menciona las minorías étnicas en su artículo 13, que establece: Los Estados partes en el presente Pacto reconocen el derecho de toda persona a la educación. Convienen en que la educación debe orientarse hacia el pleno desarrollo de la personalidad humana y del sentido de su dignidad, y debe fortalecer el respeto por los derechos humanos y las libertades fundamentales. Convienen asimismo en que la educación debe capacitar a todas las personas para participar efectivamente en una sociedad libre, favorecer la comprensión, la tolerancia y la amistad entre todas las naciones y entre todos los grupos raciales, étnicos o religiosos, y promover las actividades de las Naciones Unidas en pro del mantenimiento de la paz.

213 En 1953, la OIT publicó el primer estudio sobre las condiciones de vida y de trabajo de los pueblos indígenas. A ello siguió la adopción del Convenio No. 107 sobre Poblaciones Indígenas y Tribales en 1957, cuyo texto reflejó el clima prevaleciente en aquella época, en la que los Estados promovían políticas no sólo colonialistas, sino paternalistas de integración y asimilación de las poblaciones indígenas. En 1989, el Convenio No. 169 de la OIT sobre Pueblos Indígenas y Tribales en Países Independientes se dio como resultado de crecientes críticas a la concepción asimilacionista del Convenio No. 107 de la OIT. Véase, entre otros, Oficina Internacional del Trabajo, Las poblaciones Indígenas, Ginebra, Oficina Internacional de Trabajo, 1953. Stavenhaguen Ro- 
Este libro forma parte del acervo de la Biblioteca Jurídica Virtual del Instituto de Investigaciones Jurídicas de la UNAM

hasta 2007 que se firma la Declaración sobre los Derechos de los Pueblos Indígenas de las Naciones Unidas. ${ }^{214}$

Merece especial referencia el Convenio No. 169 de la OIT, que ha permeado distintas decisiones internacionales. Dicho instrumento reconoce la tenencia colectiva de los pueblos indígenas y tribales sobre sus tierras. Es importante destacar que la denominación genérica tierras incluye el concepto de territorios, es decir, "lo que cubre la totalidad del hábitat de las regiones que los pueblos interesados ocupan o utilizan de alguna manera". ${ }^{215}$ Asimismo, protege el derecho de propiedad y posesión sobre tierras que tradicionalmente ocupan los pueblos indígenas, incluyendo que cuando las tierras no las ocupen únicamente ellos, se deben tomar medidas que garanticen su acceso libre para realizar actividades económicas o culturales, y que se establezcan mecanismos adecuados para reivindicar sus tierras cuando esto fuera necesario. ${ }^{216}$ Además, es el principal instrumento que puede garantizar el derecho de los pueblos a no ser trasladados y desalojados de sus territorios frente a gran-

dolfo, Los derechos humanos de los pueblos indígenas, Comisión Nacional de Derechos Humanos, México, 2000, p. 62. Convenio 169 de la Organización Internacional del Trabajo de 1989, artículo 10.

${ }^{214}$ Dicha declaración — que no tiene el carácter vinculante de un tratadohace hincapié en el derecho de los pueblos indígenas a vivir con dignidad, a mantener y fortalecer sus propias instituciones, culturas y tradiciones, y a buscar su propio desarrollo determinado libremente de conformidad con sus propias necesidades e intereses. Asimismo, afirma que los pueblos indígenas tienen derecho, como pueblo o como personas, al disfrute pleno de todos los derechos humanos y las libertades fundamentales reconocidos por la Carta de las Naciones Unidas, la Declaración Universal de Derechos Humanos y la normativa internacional de los derechos humanos. Cfr. Stavenhaguen Rodolfo, Multiculturalismo y Derechos de los Pueblos Indígenas en México, Comisión Nacional de Derechos Humanos, México, 2011, p. 215.

${ }^{215}$ Convenio 169 de la Organización Internacional del Trabajo de 1989, artículo 13.

${ }^{216}$ Convenio 169 de la Organización Internacional del Trabajo de 1989, artículos 15 y 16. 
des proyectos de explotación y extracción de recursos naturales por empresas, a través de la consulta. ${ }^{217}$ Asimismo, implica una protección especial que abarca el aprovechamiento, administración y conservación de los recursos dentro del territorio indígena/tribal correspondiente. ${ }^{218}$

Ahora corresponde hacer referencia a los pronunciamientos de los diferentes órganos del Sistema Universal de Derechos Humanos.

\section{Comité de Derechos humanos de la Organización DE LAS NACIONES UNIDAS}

\section{A. Casos}

A partir de la entrada en vigor del Primer Protocolo Facultativo al Pacto Internacional de Derechos Civiles y Políticos (PIDCP), el Comité de Derechos Humanos (Comité DH) ha examinado diversas comunicaciones individuales relacionadas con derechos de los pueblos indígenas y tribales.

En el Caso Lovelance vs. Canadá, la demandante era una indígena malisset, quien, bajo la ley canadiense, podía vivir en la reserva y gozar de los beneficios sociales subsidiados. Sin embargo, cuando se casó con un no indígena, perdió su estatus de indígena y, con ello, sus derechos de beneficios y el derecho a vivir en la reserva. Esta pérdida de derechos para las mujeres estaba dispuesta en la Ley India.

217 Corte IDH, Caso Pueblo Indígena Kichwa de Sarayaku vs. Ecuador. Fondo y Reparaciones. Sentencia del 27 de junio de 2012. Serie C, No. 245, párr. 164.

218 Convenio 169 de la Organización Internacional del Trabajo de 1989, artículo 15. 
En el caso se alegó la vulneración del derecho a la no discriminación (artículo 2.1), a la igualdad entre mujeres y hombres (artículo 3o.), a la protección de la familia e igualdad de derechos de los esposos (artículo 4o.), a la protección igual ante la ley, independientemente de la raza, lengua, religión, origen nacional o social, propiedad, opinión política o de otro tipo, nacimiento o estatus (artículo 26) y a los derechos de las minorías a gozar y usar su cultura, lengua y religión en comunidad con otros miembros (artículo 27) del PIDCP.

El Comité DH analizó las violaciones a la luz de los derechos de las minorías y concluyó que se había negado a la mujer su derecho a gozar de su cultura en compañía de otros miembros de la comunidad, porque su cultura no existía más allá de los límites de su reserva, donde se le negó el derecho legal de residencia. También señaló que la Ley India no era razonable. ${ }^{219}$

En el Caso Ominayak y Lake Lubicon Band vs. Canadá, el gobierno de la provincia de Alberta había otorgado arrendamientos a corporaciones privadas para explotar petróleo, gas, madera y otros recursos en tierras y territorios del pueblo Lubicon Cree. Además había otorgado un permiso para la construcción de una planta maderera.

En el asunto se alegó la violación del derecho de autodeterminación, el derecho de disponer de la riqueza natural y de los recursos, y el derecho a que los medios de subsistencia fueran salvaguardados (artículo 10.), así como el derecho de las minorías (artículo 27). El Comité DH rechazó las posibles violaciones del artículo 1o. manifestando que según el Protocolo Facultativo 1o. del PIDCP, sólo podían alegarse peticiones individuales. $Y$ con relación al artículo 27 , concluyó que los derechos protegidos incluían derechos de las personas, en comunidad con otras,

219 ONU, Comité de Derechos Humanos, Caso Lovelance vs. Canadá, 30 de julio de 1981, CCPR/C/13/D/24/1977, párr. 17. 
para dedicarse a actividades económicas y sociales que eran parte de la cultura y la comunidad a la que pertenecen. ${ }^{220}$

En el Caso Apirana Mahuika et al. vs. Nueva Zelanda, los demandantes, diecinueve personas maoríes, alegaron la violación de su derecho de consulta. El caso esta relacionado con la Ley de Acuerdo del Tratado de Waitangi de 1992, que expropiaba sus recursos pesqueros comerciales maoríes, que habían sido reconocidos por la Corona Británica en 1840.

Los demandantes declararon la violación a su derecho a la autodeterminación (artículo 10.), al goce de derechos (artículo 2o.), al reconocimiento de la personalidad legal (artículo 16), a la libertad de pensamiento y expresión (artículo 18), a la igualdad ante la ley y prohibición de discriminación (artículo 26) y a los derechos de las minorías (artículo 27). En específico, sobre la ley que expropiaba sus recursos pesqueros, consideraron que violaba los derechos a la autodeterminación y de minorías del PIDCP, y expusieron que la pesca es un aspecto fundamental de la cultura y religión de los maoríes. ${ }^{221}$

Este caso es, quizá, uno de los más relevantes en la jurisprudencia del Comité $\mathrm{DH}$, pues plantea el tema del llamado derecho de veto de los procesos de consulta de los pueblos indígenas cuando se afecte su territorio. Al respecto, el Comité DH concluyó:

...que el Estado Parte emprendió un complejo proceso de consulta para lograr un amplio apoyo maorí a la solución y a la reglamentación de las actividades pesqueras a nivel nacional. Se consultó a las comunidades y a las organizaciones nacionales maoríes y sus propuestas quedaron reflejadas en

220 ONU, Comité de Derechos Humanos, Ominayak y Lake Lubicon Band vs. Canadá, 26 de marzo de 1990, CCPR/C/38/D/167/1984, párr. 32.2.

221 ONU, Comité de Derechos Humanos, caso Apirana Mahuika et al. vs. Nueva Zelanda, 27 de octubre de 2000, CCPR/C/70/D/547/1993, párr. 8.2. 
la solución adoptada. La solución no se promulgó en forma de ley hasta disponer del informe de los representantes de los maoríes según el cual había un sustancial apoyo a la solución. Para muchos maoríes, la ley era una solución aceptable de sus reivindicaciones. El Comité ha tomado nota de las reclamaciones de los autores en el sentido de que ni ellos ni la mayoría de los miembros de sus tribus estaban de acuerdo con la solución, y de que afirman que no se habían tenido en cuenta sus derechos como miembros de la minoría maorí. En tales circunstancias, cuando el derecho de personas a disfrutar de su propia cultura está en conflicto con el ejercicio de derechos paralelos de otros miembros del grupo de la minoría, o de la minoría en su conjunto, el Comité puede considerar si esa limitación favorece a los intereses de todos los miembros de la minoría y si hay una justificación razonable y objetiva para su aplicación a las personas que se declaran afectadas adversamente.

En el proceso de consulta se prestó especial atención al significado cultural y religioso de la pesca para los maoríes, entre otras cosas garantizando la posibilidad de que particulares y comunidades maoríes pudieran dedicarse a actividades pesqueras no comerciales. Aunque le preocupa que la solución alcanzada haya contribuido a dividir a los maoríes, el Comité llega a la conclusión de que el Estado Parte, al participar en amplias consultas antes de promulgar la nueva legislación y al atender específicamente a la sostenibilidad de las actividades pesqueras maoríes, ha adoptado las medidas necesarias para que la solución sobre las pesquerías y su promulgación como ley, incluido el sistema de gestión de cuotas, sean compatibles con el artículo $27 .{ }^{222}$

222 ONU, Comité de Derechos Humanos, Caso Apirana Mahuika et al. vs. Nueva Zelanda, 27 de octubre de 2000, CCPR/C/70/D/547/1993, párrs. 9.6 y 9.8 . 
En el Caso George Howard vs. Canadá, el demandante indígena había sido condenado a una multa de parte de las instancias nacionales por haber pescado fuera del área establecida a su comunidad y en tiempos de veda. En consecuencia, impugnaba la imposibilidad de ejercer individual y colectivamente sus derechos aborígenes a la pesca, pues ello amenazaba su supervivencia cultural, espiritual y social. Sostenía, además, que la caza, la pesca y la recolección son elementos esenciales de su cultura y que la denegación del derecho de practicarlas ponía en peligro la transmisión de la cultura a otras personas y a las generaciones futuras. El demandante alegó la violación de la adecuación del derecho interno (artículo 2.2) y el derecho de las minorías (artículo 27).

Por un lado, Canadá expuso que el demandante tenía derecho a pescar durante todo el año en las reservas que se le habían asignado a la comunidad y además — mediante una licenciatambién podía pescar fuera de éstas y en zonas adyacentes, aun en tiempos de veda. Por otro lado, el demandante consideró que en las zonas adyacentes no había suficientes peces para ejercer la pesca tradicional y que solicitar una licencia constituía un privilegio y no correspondía a su derecho. ${ }^{223}$

Respecto de la licencia, el Comité DH reiteró el Caso Kitok vs. Suecia, en el sentido que los Estados parte del pacto pueden reglamentar actividades que constituyan un elemento esencial de la cultura de una minoría, siempre que no represente una denegación de facto de un derecho. Por tanto, consideró que no podía aceptar el alegato de que la licencia para pescar fuera de la reserva en tiempos de veda constituyera una violación a los

223 ONU, Comité de Derechos Humanos, Caso George Howard vs. Canadá, 26 de julio de 2005, CCPR/C/84/D/879/1999, párr. 12.6. 
Este libro forma parte del acervo de la Biblioteca Jurídica Virtual del Instituto de Investigaciones Jurídicas de la UNAM

derechos, en específico, con relación al derecho de minorías (artículo 27). ${ }^{224}$

Con independencia de este análisis, el Comité consideró que no podía pronunciarse respecto de la demanda, pues ante dicha instancia internacional, ambas partes habían expuesto una serie de argumentos que los tribunales internos no habían tenido oportunidad de conocer, por lo que no se encontraba "en condiciones de extraer conclusiones independientes sobre las circunstancias concretas en que el autor puede ejercer su derecho a pescar y sobre las consecuencias para su derecho a disfrutar de su propia cultura". ${ }^{225}$

El Caso Ángela Poma Poma vs. Perú, el único latinoamericano en materia territorial indígena ante el Comité, es interesante, más allá del fondo, por el reclamo sobre la ausencia de un recurso efectivo a la luz del derecho de las minorías (artículo 27).

El Comité DH se refirió a la demandante como "una mujer perteneciente a una minoría étnica", sin decir que era parte de un pueblo indígena, aun cuando uno de los alegatos principales era que, a nivel interno, las autoridades políticas y judiciales no habían tomado en cuenta los argumentos de la comunidad y sus representantes por el hecho de ser indígenas, por lo que se violaba el derecho a la igualdad ante los tribunales (artículo 14). ${ }^{226} \mathrm{Al}$ respecto se señaló:

224 Ibidem, párr. 12.7.

225 Ibidem, párr. 12.11.

226 ONU, Comité de Derechos Humanos, Caso Ángela Poma Poma vs. Perú, 29 de marzo de 2009, CCPR/C/95/D/1457/2006, párr. 3.4. Así el Comité señaló que: “6.4. Por el contrario, la alegación de una violación del párrafo 1 del artículo 14 debido a que las autoridades no tomaron en cuenta las quejas por tratarse de miembros de una comunidad indígena no ha sido suficientemente fundamentada a efectos de la admisibilidad, y debe ser declarada inadmisible con arreglo al artículo 2 del Protocolo Facultativo". ONU, Comité de Derechos Humanos, Caso Ángela Poma Poma vs. Perú, 29 de marzo de 2009, CCPR/ C/95/D/1457/2006, párr. 6.4. 
El Comité recuerda su Observación General No. 23, con arreglo a la cual el artículo 27 establece y reconoce un derecho que se confiere a las personas pertenecientes a grupos de minorías y que constituye un derecho separado, que se suma a los demás derechos de que pueden disfrutar todas las personas en virtud del Pacto. En algunos de sus aspectos los derechos de las personas amparadas en virtud de ese artículo - por ejemplo, el disfrute de una determinada cultura- pueden guardar relación con modos de vida estrechamente asociados al territorio y al uso de sus recursos. Esto podría ser particularmente cierto en el caso de los miembros de comunidades indígenas que constituyen una minoría. Dicha Observación General señala igualmente, por lo que se refiere al ejercicio de los derechos culturales protegidos por el artículo 27, que la cultura se manifiesta de muchas formas, inclusive un modo particular de vida relacionado con el uso de recursos terrestres, especialmente en el caso de los pueblos indígenas. Ese derecho puede incluir actividades tradicionales tales como la pesca o la caza y el derecho a vivir en reservas protegidas por la ley. El goce de esos derechos puede requerir la adopción de medidas jurídicas positivas de protección y medidas para asegurar la participación eficaz de los miembros de comunidades minoritarias en las decisiones que les afectan. La protección de esos derechos tiene por objeto garantizar la preservación y el desarrollo continuo de la identidad cultural, enriqueciendo así el tejido social en su conjunto.

El Comité ha reconocido en casos anteriores que los derechos protegidos por el artículo 27 incluyen el derecho de las personas a emprender, en forma mancomunada, actividades económicas y sociales que forman parte de la cultura de la comunidad a la que pertenecen. En el presente caso resulta indiscutible que la autora es miembro de una minoría étnica y que la cría de camélidos constituye un elemento esencial de la cultura de la comunidad aymara, siendo ésta una forma de sub- 
sistencia y una práctica ancestral que se ha transmitido de padres a hijos. ${ }^{227}$

En los Casos Kitok vs. Suecia, Ilmani Lansman et al. vs. Finlandia, F. J. Lansman vs. Finlandia, Äärelä y Näkkäläjävi vs. Finlandia y Jouni E. Länsman, Eino A. Länsman y el Comité de Pastores Muotkatunturi vs. Finlandia, ${ }^{228}$ relacionados con miembros de las comunidades Sami dispersas en territorio sueco y finlandés, la jurisprudencia temprana del Comité DH no los consideraba propiamente indígenas, sino minorías (pastores de renos). Sin embargo, en el Caso Kalevi Paadar, Eero Paadar y su familia, Veijo Paadar, y Kari Alatorvinen vs. Finlandia, el Comité de $\mathrm{DH}$ dio un vuelco a su jurisprudencia y, por primera vez, consideró de manera explícita que se trataba de una comunidad indígena. ${ }^{229}$

Es importante destacar, respecto del Caso Poma Poma y de los Casos de las Comunidades Samis, que el Comité, al no referir directamente (como sí lo hace el SIDH) al Convenio No. 169 de la OIT y, por ende, a la autoadscripción como elemento identificador del ser indígena, no explica la razón por la cual no considera a la primera como indígena aymara, ni a los segundos como pueblo indígena en su jurisprudencia temprana.

Finalmente, el Comité DH también ha conocido casos en los cuales se ha involucrado la desaparición y ejecución de líderes

227 ONU, Comité de Derechos Humanos, Caso Ángela Poma Poma vs. Perú, 29 de marzo de 2009, CCPR/C/95/D/1457/2006, párrs. 7.2 y 7.3.

228 En http://juris.ohchr.org/search/results/1?typeOfDecisionFilter=0\&coun tryFilter $=0 \&$ treatyFilter $=0$.

229 En todos los casos enunciados, desde el Caso Lovelance (1981) hasta el Caso Poma Poma (2009), el Comité DH había conceptualizado a las víctimas como parte de una "minoría étnica", sin darles el calificativo de comunidades indígenas, lo cual no excluye que los casos hayan versado sobre pueblos indígenas. 
indígenas, ${ }^{230}$ y sobre la posibilidad que tienen las comunidades indígenas de usar su propia lengua para difundir conocimientos en revistas impresas. ${ }^{231}$

\section{B. Observaciones Generales}

El Comité de Derechos Humanos ha tenido una notable contribución en la interpretación a favor de los derechos de los pueblos indígenas y tribales a través de sus observaciones generales.

En la Observación General No. 12 consideró que el derecho a la libre determinación reconocido en el artículo 10. reviste especial importancia, ya que su ejercicio es una condición esencial para la eficaz garantía y observancia de los derechos humanos individuales y para la promoción y fortalecimiento de esos derechos. Por esta razón, los Estados han enunciado el derecho de libre determinación en una disposición de derecho positivo en ambos Pactos [PIDCP y PIDESC] e incluido en dicha disposición como artículo 10., separado de todos los demás derechos reconocidos en dichos instrumentos y anterior a los mismos. ${ }^{232}$

Adicionalmente, señaló que el artículo 10. reconoce un derecho inalienable de todos los pueblos, que se describe en sus párrafos 1 y 2 . En virtud de ese derecho, los pueblos "establecen libremente su condición política y proveen asimismo a su desarrollo económico, social y cultural". Este derecho y sus obligaciones están vinculados a otras disposiciones del Pacto

230 ONU, Comité de Derechos Humanos, Caso Vicente et al. vs. Colombia, 29 de julio de 1997, CCPR/C/60/D/612/1995.

231 ONU, Comité de Derechos Humanos, caso Mavlonov and Sa'di vs. Uzbekistan, 19 de marzo de 2009, CCPR/C/95/D/1334/2004.

232 ONU, Comité de Derechos Humanos, Observación General No. 12 (Derecho a la libre determinación), 12 de abril de 1984, párr. 1. 
Internacional de Derechos Civiles y Políticos y a normas de derecho internacional. ${ }^{233}$

Según el Comité DH, para garantizar este derecho, los Estados parte deberían describir los procesos constitucionales y políticos que permiten su ejercicio. ${ }^{234}$ Además, se afirma un aspecto especial del contenido económico del derecho de libre determinación, a saber, el derecho de los pueblos para "disponer libremente de sus riquezas y recursos naturales, sin perjuicio de las obligaciones que derivan de la cooperación económica internacional basada en el principio del beneficio recíproco, así como del derecho internacional. En ningún caso podrá privarse a un pueblo de sus propios medios de subsistencia". ${ }^{235}$

En la Observación General No. 23, ${ }^{236}$ el Comité DH consideró que existe una diferencia entre los derechos de las minorías (artículo 27) y el derecho a la libre determinación (artículo 10.), concluyendo que:

El Pacto hace una diferenciación entre el derecho a la libre determinación y el derecho amparado en virtud del artículo 27. En el primer caso, se trata de un derecho perteneciente a los pueblos, que se rige por disposiciones separadas del Pacto (parte I). La libre determinación no es un derecho re-

${ }^{233}$ Ibidem, párr. 2.

234 Ibidem, párr. 4.

235 Ibidem, párr. 5.

${ }^{236}$ El Comité expresó que: 3.2. El disfrute de los derechos a los que se refiere el artículo 27 no menoscaba la soberanía y la integridad territorial de un Estado Parte. No obstante, en algunos de sus aspectos los derechos de las peronas amparadas en virtud de ese artículo - por ejemplo, el disfrute de una determinada cultura - pueden guardar relación con modos de vida estrechamente asociados al territorio y al uso de sus recursos. Esto podría ser particularmente cierto en el caso de los miembros de comunidades indígenas que constituyen una minoría. ONU, Comité de Derechos Humanos, Observación General No. 23 (Derechos de las minorías, art. 27 del Pacto), 26 de abril de 1994, CCPR/C/21/Rev.1/Add.5, párr. 3.2. 
conocido con arreglo al Protocolo Facultativo. Por otra parte, el artículo 27 se relaciona con los derechos reconocidos a las personas en cuanto tales y, al igual que los artículos relacionados con los demás derechos personales reconocidos a todos. ${ }^{237}$

Respecto de los derechos culturales protegidos por esta disposición, el Comité DH expresó que:

...la cultura se manifiesta de muchas formas, inclusive un modo particular de vida relacionado con el uso de recursos terrestres, especialmente en el caso de los pueblos indígenas. Ese derecho puede incluir actividades tradicionales tales como la pesca o la caza y el derecho a vivir en reservas protegidas por la ley. El goce de esos derechos puede requerir la adopción de medidas jurídicas positivas de protección y medidas para asegurar la participación eficaz de los miembros de comunidades minoritarias en las decisiones que les afectan. ${ }^{238}$

En la Observación General No. 25, relativa a la participación en los asuntos públicos y el derecho al voto reconocido en el artículo 25 del PIDCP, el Comité DH expresó que

...los derechos consagrados en [dicho] artículo... están relacionados con el derecho de los pueblos a la libre determinación, aunque son distintos de él. De conformidad con el párrafo 1 del artículo 10., los pueblos gozan del derecho a determinar libremente su condición política, y del derecho a elegir la forma de su constitución o gobierno. El artículo 25 trata del derecho

237 ONU, Comité de Derechos Humanos, Observación General No. 23 (Derechos de las minorías, artículo 27 del Pacto), 26 de abril de 1994, CCPR/C/21/ Rev.1/Add.5, párr. 3.1.

238 Ibidem, párr. 7. 
de las personas a participar en los procesos de dirección de los asuntos públicos. ${ }^{239}$

\section{COMité de DERECHOS ECONÓMICOS, SOCIALES Y CULTURALES}

\section{Observaciones Generales}

El Comité de Derechos Económicos, Sociales y Culturales (Comité DESC), órgano de supervisión de la aplicación del Pacto Internacional de Derechos Económicos, Sociales y Culturales (PIDESC), ha contribuido de manera significativa al desarrollo de tales derechos dentro del sistema universal, especialmente sobre la necesidad de proveer recursos judiciales, u otros recursos efectivos, que permitan a los titulares de derechos presentar quejas en casos de alegada violación.

Es importante destacar que - a diferencia del Comité $\mathrm{DH}$, cuyo protocolo facultativo entró en vigor en 1976 y, por tanto, puede conocer comunicaciones individuales - el Comité DESC fue creado en 1985 y el protocolo facultativo al PIDESC, adoptado en 2008, entró en vigor en 2013. Por tanto, su labor jurisprudencial es reciente y ha decidido pocos casos, ninguno de ellos sobre pueblos indígenas y tribales. No obstante, el Comité ha subsanado esta ausencia, refiriendo en la mayoría de sus observaciones generales a los pueblos indígenas, de manera explícita, como un grupo en situación de vulnerabilidad en el disfrute de los derechos económicos, sociales y culturales.

Así, por ejemplo, en la Observación General No. 7, relativa al derecho a la vivienda en los contextos de desalojos forzosos, el Comité DESC consideró que los pueblos indígenas —al

239 Ibidem, párr. 2. 
igual que otros sectores en situación de vulnerabilidad - se ven afectados en medida desproporcionada por la práctica de desalojos forzosos. También consideró que las mujeres indígenas son particularmente vulnerables a causa de la discriminación jurídica, y a otras formas de discriminación, en materia del derecho de propiedad (incluida la propiedad de una vivienda) - 0 del derecho de acceso a la propiedad o a la vivienda-, y de su particular vulnerabilidad a los actos de violencia y abuso sexual cuando se quedan sin hogar. ${ }^{240}$

En la Observación General No. 12, respecto al derecho a la alimentación en relación con la accesibilidad física, se consideró que la alimentación debe ser asequible a todos, incluidos los individuos físicamente vulnerables, por lo que es necesario prestar atención y, a veces, conceder prioridad a la accesibilidad de los alimentos a quienes viven en zonas propensas a los desastres y a otros grupos particularmente desfavorecidos, como los pueblos indígenas, cuyo acceso a tierras ancestrales puede verse amenazado. ${ }^{241}$

En la Observación General No. 14, relativa al derecho a la salud, el Comité expresó que:

...los pueblos indígenas tienen derecho a medidas específicas que les permitan mejorar su acceso a los servicios de salud y a las atenciones de la salud y que los servicios de salud deben ser apropiados desde el punto de vista cultural, es decir, tener en cuenta los cuidados preventivos, las prácticas curativas y las medicinas tradicionales. Además, los Estados

240 ONU, Comité de Derechos Económicos, Sociales y Culturales, Observación General No. 7, El derecho a una vivienda adecuada (párrafo 1 del artículo 11 del Pacto): los desalojos forzosos, 16 periodo de sesiones, U.N. Doc. E/1999/22, 1997, párr. 10.

241 ONU, Comité de Derechos Económicos, Sociales y Culturales, Observación General No. 12, El derecho a una alimentación adecuada (artículo 11), 20 periodo de sesiones, U.N. Doc. E/C.12/1999/5, 1999, párr. 13. 
deben proporcionar recursos para que los pueblos indígenas establezcan, organicen y controlen esos servicios de suerte que puedan disfrutar del más alto nivel posible de salud física y mental. También deberán protegerse las plantas medicinales, los animales y los minerales que resultan necesarios para el pleno disfrute de la salud de los pueblos indígenas. El Comité DESC observó que, en las comunidades indígenas, la salud del individuo se suele vincular con la salud de la sociedad en su conjunto y presenta una dimensión colectiva. A este respecto, el Comité DESC consideró que las actividades relacionadas con el desarrollo que inducen al desplazamiento de poblaciones indígenas, contra su voluntad, de sus territorios y entornos tradicionales, con la consiguiente pérdida por esas poblaciones de sus recursos alimenticios y la ruptura de su relación simbiótica con la tierra, ejercen un efecto perjudicial sobre a salud de esas poblaciones. ${ }^{242}$

En la Observación General No. 15, relativa al derecho al agua, el Comité DESC consideró indispensable que los Estados garanticen un acceso suficiente al agua para la agricultura de subsistencia y para asegurar la supervivencia de los pueblos indígenas. ${ }^{243}$ Además, señaló que los Estados partes deben prestar especial atención a las personas y grupos que tradicionalmente han tenido dificultades para ejercer el derecho al agua, entre otros, a los pueblos indígenas que deben tener acceso a las fuentes tradicionales de agua en las zonas rurales libres de

242 ONU, Comité de Derechos Económicos, Sociales y Culturales, Observación General No. 14, El derecho al disfrute del más alto nivel posible de salud (artículo 12 del Pacto Internacional de Derechos Económicos, Sociales y Culturales), 22 periodo de sesiones, U.N. Doc. E/C.12/2000/4, 2000, párr. 27.

243 ONU, Comité de Derechos Económicos, Sociales y Culturales, Observación General No. 15, Aplicación del Pacto Internacional de los Derechos Económicos, Sociales y Culturales, El derecho al agua (artículos 11 y 12 del Pacto), 29 periodo de sesiones, U.N. Doc. HRI/GEN/1/Rev.7 at 117, 2002. párr. 7. 
toda injerencia ilícita y contaminación. ${ }^{244}$ Finalmente, destacó que los Estados deben facilitar recursos para que los pueblos indígenas planifiquen, ejerzan y controlen el acceso al agua. ${ }^{245}$

En la Observación General No. 17, sobre el derecho de toda persona a beneficiarse de la protección de los intereses morales y materiales que le correspondan por las producciones científicas, literarias o artísticas de que sea autor(a), el Comité consideró que la accesibilidad a la información comprende el derecho a buscar, recibir y difundir información sobre la estructura y el funcionamiento del régimen legal o reglamentario para proteger los intereses morales y materiales de los autores que les correspondan por sus producciones científicas, literarias y artísticas, incluida la información sobre la legislación y los procedimientos pertinentes; dicha información deberá ser comprensible para todos y publicada en los idiomas de los pueblos indígenas. ${ }^{246}$

En la misma observación, respecto del derecho a beneficiarse de la protección de los intereses morales y materiales por las producciones científicas, literarias o artísticas de los pueblos indígenas, consideró que los Estados deberían adoptar medidas para garantizar la protección efectiva de los intereses de los pueblos indígenas en relación con sus producciones, que a menudo son expresiones de su patrimonio cultural y sus conocimientos tradicionales. Estas medidas, a criterio del Comité DESC, podrían comprender la adopción de medidas para reco-

244 Ibidem, párr. 16, c.

245 Ibidem, párr. 16, d.

246 ONU, Comité de Derechos Económicos, Sociales y Culturales, Observación General No. 17, Aplicación del Pacto Internacional de los Derechos Económicos, Sociales y Culturales, El Derecho de toda persona a beneficiarse de la protección de los intereses morales y materiales que le correspondan por razón de las producciones científicas, literarias o artísticas de que sea autor(a) (artículo 15 del Pacto, apartado c) párrafo 1), 35 periodo de sesiones, U.N. Doc. E/C.12/GC17, 2006, párr. 17, iii. 
nocer, registrar y proteger la autoría individual o colectiva de los pueblos indígenas en el marco de los regímenes nacionales de derechos de propiedad intelectual, y debería impedir el uso no autorizado de las producciones científicas, literarias y artísticas de los pueblos indígenas por terceros. Además, estimó que los Estados parte deberían respetar, siempre que sea posible, el principio del consentimiento libre, previo y fundado, de los autores indígenas en cuestión y las formas orales $u$ otras formas consuetudinarias de transmisión de la producción científica, literaria o artística y, de proceder, deberían velar por que los pueblos indígenas administren de forma colectiva los beneficios derivados de sus producciones. ${ }^{247}$

En similar sentido, en la Observación General No. 21, sobre el derecho de toda persona a participar en la vida cultural, el Comité DESC concluyó, en relación a los pueblos indígenas, que:

Los Estados partes deben adoptar medidas para garantizar que el ejercicio del derecho a participar en la vida cultural tenga debidamente en cuenta los valores de la vida cultural, que pueden ser de carácter sólidamente comunitario o que sólo pueden ser expresados y ejercidos como comunidad por los pueblos indígenas. La fuerte dimensión colectiva de la vida cultural de los pueblos indígenas es indispensable para su existencia, bienestar y desarrollo integral, y comprende el derecho a las tierras, territorios y recursos que tradicionalmente han poseído, ocupado o de otra forma utilizado o adquirido. Hay que respetar y proteger los valores culturales

247 ONU, Comité de Derechos Económicos, Sociales y Culturales, Observación General No. 17, Aplicación del Pacto Internacional de los Derechos Económicos, Sociales y Culturales, El derecho de toda persona a beneficiarse de la protección de los intereses morales y materiales que le correspondan por razón de las producciones científicas, literarias o artísticas de que sea autor(a) (artículo 15 del Pacto, apartado c) párrafo 1), 35 periodo de sesiones, U.N. Doc. E/C.12/GC17, 2006, párr. 32. 
y los derechos de los pueblos indígenas asociados a sus tierras ancestrales y a su relación con la naturaleza, a fin de evitar la degradación de su peculiar estilo de vida, incluidos los medios de subsistencia, la pérdida de recursos naturales $\mathrm{y}$, en última instancia, su identidad cultural. Por lo tanto, los Estados partes deben tomar medidas para reconocer y proteger los derechos de los pueblos indígenas a poseer, explotar, controlar y utilizar sus tierras, territorios y recursos comunales y, en los casos en que se hubieren ocupado o utilizado de otro modo esas tierras o territorios sin su consentimiento libre e informado, adoptar medidas para que les sean devueltos.

...Los pueblos indígenas tienen derecho a actuar colectivamente para que se respete su derecho a mantener, controlar, proteger y desarrollar su patrimonio cultural, sus conocimientos tradicionales, sus expresiones culturales tradicionales y las manifestaciones de sus ciencias, tecnologías y culturas, comprendidos los recursos humanos y genéticos, las semillas, las medicinas, el conocimiento de las propiedades de la fauna y la flora, las tradiciones orales, la literatura, los diseños, los deportes y juegos tradicionales, y las artes visuales e interpretativas. Los Estados partes deben respetar también el principio del consentimiento libre, previo e informado de los pueblos indígenas en todos los aspectos concernientes al ámbito de aplicación de sus derechos específicos. ${ }^{248}$

En la Observación General No. 22, sobre derechos sexuales y reproductivos, el Comité DESC refirió que las mujeres indígenas sufren doble condición de vulnerabilidad, lo que puede acarrear formas de discriminación múltiple o interseccional. ${ }^{249}$

248 ONU, Comité de Derechos Económicos, Sociales y Culturales, Observación General No. 21, El derecho a participar en la vida cultural (artículo 15, párrafo 1 a) del Pacto), 43 periodo de sesiones, U.N. Doc. E/C.12/GC/21/ Rev.1, 2010, párrs. 36 y 38.

249 ONU, Comité de Derechos Económicos, Sociales y Culturales, Observación General No. 22: El derecho a la salud sexual y reproductiva (artículo 12), E/C.12/GC/22, 4 de marzo de 2016, párr. 30. 
Finalmente, en la Observación General No. 23, sobre derecho al trabajo, referente a condiciones de trabajo equitativas y satisfactorias, el Comité DESC expresó en lo relacionado al derecho de iguales oportunidades de promoción a través de procedimientos equitativos, transparentes y basados en el mérito que respeten los derechos humanos, que cobraba especial relevancia, al igual que para otros grupos, en el caso de los pueblos indígenas. ${ }^{250}$

\section{OTROS COMITÉS}

El Comité para la Eliminación de la Discriminación Racial, en su Observación General No. 23, relativa a derechos de los pueblos indígenas, expresó que los Estados deben respetar la cultura, la historia, el idioma y el modo de vida de estos pueblos, como un factor de enriquecimiento de la identidad cultural del Estado. Además, consideró que se debía proporcionar a los pueblos indígenas las condiciones que les permitan un desarrollo económico y social sostenible; que tengan participación efectiva en la vida pública y que no se adopte decisión alguna directamente relacionada con sus derechos e intereses sin su consentimiento informado, y que se garantice que las comunidades indígenas puedan ejercer su derecho a practicar y reavivar sus tradiciones, así como costumbres culturales y presenvar y practicar su idioma. ${ }^{251}$

${ }^{250}$ ONU, Comité de Derechos Económicos, Sociales y Culturales, Observación General No. 23: El derecho a condiciones favorables de trabajo (artículo 7o.), E/C.12/GC/23, 26 de abril de 2016, párrs. 31 y 56.

${ }^{251}$ ONU, Comité para la Eliminación de la Discriminación Racial, Recomendación General No. 23, relativa a los derechos de los pueblos indígenas, 1997, párr. 4 (incisos a-e). También se pueden encontrar otras referencias en las Recomendaciones Generales: No. 24 párrs 1, 2, 3, No. 25, párr. 2/ No. 31, párrs. 36 y 41/ No. 32, párrs. 15 y 26; No. 33, párr. inciso f); No. 34 párrs. 6 y 9. 
Por su parte, el Comité de los Derechos del Niño, en su Observación General No. 11, se pronunció sobre los derechos de los niños indígenas. Esta observación enmarca diversos derechos que deben ser protegidos por los Estados parte de la Convención sobre los Derechos del Niño de las Naciones Unidas. Así, desarrolló aspectos relativos a la no discriminación, el interés superior del niño, el derecho a la vida, a la supervivencia y al desarrollo y el respeto a las opiniones del niño, entre otros. Además, enmarca las obligaciones de los Estados en contextos específicos, como el de los niños indígenas en conflictos armados y en situación de refugio, la explotación económica, sexual y de trata, entre otros. $^{252}$

Finalmente, el Comité para los Derechos de las Personas con Discapacidad, en su Observación General No. 3, y el Comité para la Eliminación de la Violencia contra la Mujer, en su Recomendación General No. 25, han expresado que las mujeres indígenas con discapacidad y las mujeres indígenas, respectivamente, sufren formas múltiples e interseccionales de discriminación en el disfrute de sus derechos protegidos por la Convención de los Derechos de las Personas con Discapacidad y la Convención para la Eliminación de Todas las Formas de Discriminación contra la Mujer. ${ }^{253}$

${ }^{252}$ ONU, Comité de los Derechos del Niño, Observación General No. 11: Los niños indígenas y sus derechos en virtud de la Convención de los Derechos del Niño, CRC/C/GC/11, 12 de febrero de 2009.

253 ONU, Comité para los Derechos de las Personas con Discapacidad, Observación General No. 3 sobre Mujeres y niñas con discapacidad, 2 de septiembre de 2016, CRPD/C/GC/3, párr. 4, y ONU, Comité CEDAW, Recomendación General No. 25, Medidas especiales de carácter temporal (párrafo 1 del artículo 40. de la Convención sobre la Eliminación de Todas las Formas de Discriminación contra la Mujer), 2004, 30 periodo ordinario de sesiones, párrs. 12 y 28. 


\section{RELATORÍA ESPECIAL SOBRE LOS DERECHOS \\ DE LOS PUEBLOS INDÍGENAS}

En 2001, la Comisión de Derechos Humanos decidió nombrar a un relator especial sobre la situación de los derechos humanos y libertades fundamentales de los indígenas, como parte del sistema de procedimientos especiales de la Comisión, el cual ha sido renovado hasta la fecha. En este entendido, destacan los informes anuales ${ }^{254}$ y los informes por país de los relatores. ${ }^{255}$

Uno de los grandes aportes es el informe sobre industrias extractivas, y en especial, las obligaciones extraterritoriales, que establece:

...en muchos casos en que se ha identificado a empresas extractivas como responsables de violaciones de los derechos de los pueblos indígenas, o al menos se las ha relacionado con dichas violaciones, el régimen regulatorio del país en cuestión es débil y las empresas responsables están domiciliadas en otros países, por lo general mucho más desarrollados. Aun cuando los Estados no estén obligados por el derecho internacional a regular las actividades extraterritoriales de las empresas domiciliadas en su territorio con el fin de asegurar o promover la conformidad con las normas de derechos humanos, existen poderosas razones relacionadas con las políticas para que lo hagan, como se afirma en los Principios Rectores sobre las empresas y los derechos humanos. Entre esas razones figura, además de la preservación de la propia reputación del Estado, la mera obligación moral de ejercer la facultad

254 ONU, Relatoría Especial sobre los Derechos de los Pueblos Indígenas, Informes Anuales, en http://www.ohchr.org/SP/Issues/IPeoples/SRIndigenousPeoples/Pages/AnnualReports.aspx.

255 ONU, Relatoría Especial sobre los Derechos de los Pueblos Indígenas, Reportes de Países, en http://www.ohchr.org/SP/Issues/IPeoples/SRIndigenousPeoples/Pages/CountryReports.aspx. 
regulatoria del Estado para promover los derechos humanos y reducir la agitación social siempre que sea posible.

Por lo tanto, los Estados deberían adoptar medidas regulatorias para las empresas domiciliadas en su jurisdicción con objeto de prevenir y, según las circunstancias, sancionar y remediar las violaciones de los derechos de los pueblos indígenas en el extranjero de las que sean responsables o cómplices dichas empresas. [A] lgunos Estados han adoptado medidas regulatorias de alcance extraterritorial en este sentido para abordar los problemas de derechos humanos en ciertos contextos, pero con escasa aplicabilidad a los problemas específicos de los pueblos indígenas. La regulación de las actividades extraterritoriales de las empresas para promover su cumplimiento de las normas internacionales relativas a los derechos de los pueblos indígenas ayudará a establecer una cultura de respeto de esos derechos por las empresas transnacionales y aumentará la posibilidad de que las relaciones entre las empresas extractivas y los pueblos indígenas sean cordiales. ${ }^{256}$

Como se observa, el Sistema Universal de Derechos Humanos, a través de sus diferentes organismos, ha ido reconociendo los derechos de los pueblos indígenas y tribales de manera paulatina, y ha hecho importantes esfuerzos para dotar de protección a los pueblos indígenas y tribales, aunque sus decisiones no tengan la misma fuerza coercitiva que las sentencias emitidas en los diferentes sistemas regionales de derechos humanos.

256 ONU, Relator Especial sobre Pueblos Indígenas, Sr. James Anaya, Las industrias extractivas y los pueblos indígenas, 1 de julio de 2013, A/HRC/24/41, párrs. 47 y 48. 


\section{CONCLUSIÓN}

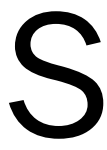

i bien el derecho internacional empezó a referirse a los derechos de los pueblos indígenas a mediados del siglo XX, no es sino hasta a partir de la década de los noventa que, con la entrada en vigor del Convenio No. 169 y de las decisiones del Sistema Interamericano de Derechos Humanos, ha brindado una especial atención a diversas situaciones de violaciones a los derechos humanos de los miembros de los pueblos indígenas y tribales. ${ }^{257}$ Ello ha respondido, sin duda, a la presencia cada vez más activa de los pueblos dentro de los ámbitos de la comunidad internacional en reclamo para el reconocimiento de sus derechos. ${ }^{258}$

De las cuestiones abordadas en el presente escrito, un tema álgido en la agenda es el relativo, indudablemente, al derecho de los pueblos a su territorio y a las decisiones sobre lo que se hace dentro de él; más aún en una realidad de grandes proyectos de extracción y explotación de recursos naturales en territorios indígenas reconocidos - $\mathrm{O}$ no reconocidos- como tales. Sin embargo, existen varios temas pendientes relacionados con los territorios indígenas y con el derecho a la consulta. No todos los países reconocen los territorios de los pueblos indígenas, ni todos los han delimitado claramente; no todas las legislaciones incluyen la consulta previa con consentimiento, y

257 Página de la Relatoría de Derechos de los Pueblos Indígenas de la Comisión IDH, en http://www.oas.org/es/cidh/indigenas/decisiones/cidh.asp.

258 Por ejemplo, se considera que la redacción del Convenio No. 169 de la OIT es de 1989 y la Relatoría de Derechos de los Pueblos Indígenas de la Comisión IDH fue creada en 1990. 
cuando lo hacen, no todas prevén los beneficios a los pueblos que brindaron su consentimiento para realizar proyectos en su territorio.

Por otro lado, quedan deudas en el trato — directa e indirectamente - discriminatorio contra miembros de pueblos indígenas. y faltan legislaciones y prácticas que prevean mecanismos que les permitan el acceso a la justicia, así como el reconocimiento de la autodeterminación como único criterio para su identificación como indígenas. Para ello no basta, evidentemente, que no existan leyes o prácticas abiertamente discriminatorias, sino que es importante que los Estados tomen medidas positivas para modificar las leyes que sean neutrales en apariencia, pero que podrían no serlo frente a un grupo históricamente discriminado, como son los pueblos indígenas en muchos países.

Los conflictos territoriales y de inmersión de industrias y megaproyectos en territorios indígenas se enmarcan en las obligaciones que emanan de instrumentos internacionales de protección de derechos territoriales de los pueblos indígenas y tribales, como, por ejemplo, que sea considerada la consulta como un principio general del derecho internacional, tal como lo ha hecho la Corte $\mathrm{IDH} .{ }^{259}$ Sin embargo, el respeto de este derecho ha resultado uno de los retos más grandes para los Estados y una de las constantes luchas de los pueblos.

Los avances a nivel internacional en esta materia son, sin duda, producto de la lucha de los propios pueblos indígenas y tribales para hacerse escuchar a nivel internacional, tras, lamentablemente, habérseles negado la justicia, a nivel interno, de la reivindicación de sus derechos. Son, y seguirán siendo, ellos mismos los principales artífices de estos cambios.

259 Corte IDH, Caso Pueblo Indígena Kichwa de Sarayaku vs. Ecuador. Fondo y Reparaciones. Sentencia del 27 de junio de 2012. Serie C, No. 245, párr. 164. 


\section{BIBLIOGRAFÍA}

CITRONI, Gabriela y QUINTANA OSUNA, Karla, "Reparations for Indigenous Peoples in the Inter-American Court", en LENZERINI, Federico (ed.), Reparations for Indigenous Peoples. International and Comparative Perspectives, Oxford University Press, 2008.

GonzÁLEZ Morales, Felipe, Sistema Interamericano de Derechos Humanos, Valencia, Tirant lo Blanch-Tratados, 2013.

O'DonNELL, Daniel, Derecho Internacional de los Derechos Humanos, Oficina del Alto Comisionado de las Naciones Unidas para los Derechos Humanos, México-Bogotá, Tecnológico de Monterrey, 2004.

StAVENHAgUeN Rodolfo, Los derechos humanos de los pueblos indígenas, México, Comisión Nacional de Derechos Humanos, 2000.

Multiculturalismo y Derechos de los Pueblos Indígenas en México, México, Comisión Nacional de Derechos Humanos, 2011.

Revistas

AnAYA, James y Grossman, Claudio, "The Case of Awas Tingni vs. Nicaragua: A New Step in the International Law of Indigenous Peoples", Arizona Journal of International and Comparative Law, vol. 19, núm. 1, 2002. 
Jurisprudencia Internacional

Comisión Interamericana de Derechos Humanos

Alegatos de la Comisión IDH ante la Corte IDH, en Corte IDH. Caso Comunidad Indígena Yakye Axa vs. Paraguay. Fondo Reparaciones y Costas. Sentencia del 17 de junio de 2005. Serie C No. 125.

$\mathrm{CIDH}$, demanda en el Caso de la Masacre de Plan de Sánchez vs. Guatemala, 25 octubre 1996, http://www.corteidh.or.cr/cf/Jurisprudencia2/ver_expediente.cfm?nld_expediente $=39 \& / a n g=e s$.

CIDH, Informe de Fondo No. 176/10, Segundo Aniceto Norín Catriman, Juan Patricio Marileo Saravia, Victor Ancalaf Llaupe y otros vs. Chile, 5 de noviembre de 2010.

$\mathrm{CIDH}$, Informe sobre la situación de los derechos humanos en Brasil, 29 de septiembre de 1997, OEA/Ser.L/N/II.97 Doc. 29, rev. 1, http://www.cidh.org/countryrep/Brasesp97/capitulo_6\%20.htm.

Comisión IDH (2009), demanda del 3 de julio de 2009 http:// www.cidh.org/demandas/12.420\%20Xakmok\%20Kasek\%20 Paraguay\%203jul09\%20ESP.pdf.

Comisión IDH, Informe de Admisibilidad No. 55/07, Comunidades Indígenas Enxet-Lamenxay y Kayleyphapoyet respecto de Paraguay, 24 de julio de 2007.

Comunidades Indígenas Mayas del Distrito de Toledo vs. Belice, https://www.cidh.oas.org/annualrep/2004sp/Belize.12053. htm.

Demanda ante la Corte IDH en el Caso de los doce Clanes Saramaka vs. la República de Suriname, http://www.oas.org/es/ cidh/decisiones/demandas.asp.

Demanda ante la Corte IDH en el Caso del Pueblo Indígena de Sarayaku vs. Ecuador, 26 de abril de 2010, http://www.oas. org/es/cidh/decisiones/demandas.asp. 
Demanda de la Comisión IDH (2005), Comunidad Indígena de Sawhoyamaxa, 2 de febrero de 2005, y la demanda de la Comisión IDH (2009), Comunidad Indígena Xákmok Kásek, 3 de julio de 2009, http://www.oas.org/es/cidh/decisiones/demandas.asp.

Informe 125-12, 26 de febrero de 2013, http://www.oas.org/es/ cidh/decisiones/corte/12.354FondoEsp.pdf.

Informe de Admisibilidad No. 55/07, 24 de julio de 2007, en el caso Comunidad Indígena Kelyenmagategma del Pueblo Enxet-Lengua y sus miembros vs. Paraguay.

Informe de Ecuador 1997, Conclusiones del Capítulo IX; Comisión IDH, Informe sobre la situación de los derechos humanos en Colombia, Capítulo X, 1999. Recomendación No. 4.

Informe de Fondo No. 40/04, Comunidades indígenas mayas del Distrito de Toledo vs. Belice, 12 de octubre de 2004. Informe de Fondo No. 75/02, Mary y Carrie Dann vs. Estados Unidos, 27 de diciembre de 2002.

Informe de Seguimiento, Acceso a la Justicia e Inclusión Social: El camino hacia el fortalecimiento de la Democracia en Bolivia. Doc. OEA/Ser/L/N/II.135, Doc. 40, 7 de agosto de 2009. Informe No. 53/01, Hermanas González Pérez vs. México, 4 de abril de 2001, http://www.cidh.org/annualrep/2000sp/capituloiii/fondo/Mexico11.565.htm.

Informe No. 79/13, 26 de enero de 2014, Pueblos Kaliña y Lokono vs. Surinam, http://www.oas.org/es/cidh/decisiones/ corte/12639FondoEs.pdf.

Informe No. 90/99, Caso 11.713, 29 de septiembre de 1999, en el caso de las Comunidades Indígenas Enxet-Lamenxay y Kayleyphapoyet (Riachito) vs. Paraguay.

Informe No. 90/99, Caso 11.713, Comunidades Indígenas EnxetLamenxay y Kayleyphapoyet (Riachito) respecto de Paraguay, 29 de septiembre de 1999. 
Informe sobre acceso a la justicia e inclusión social: El camino hacia el fortalecimiento de la democracia en Bolivia, Capítulo IV, Derechos de los pueblos indígenas y comunidades campesinas. Informe sobre derechos de los Pueblos Indígenas y Tribales sobre sus tierras ancestrales y recursos naturales. Normas y jurisprudencia del Sistema Interamericano de Derechos Humanos ("Informe sobre derechos de los Pueblos Indígenas y Tribales sobre sus tierras ancestrales y recursos naturales"), 30 de diciembre de 2009.

Medidas Cautelares: http://www.oas.org/es/cidh/indigenas/proteccion/cautelares.asp.

Corte Interamericana de Derechos Humanos

Opiniones consultivas

Condición Jurídica y Derechos Humanos del Niño. Opinión Consultiva OC-17/02 de 28 de agosto de 2002. Serie A No. 17.

El Derecho a la Información sobre la Asistencia Consular en el Marco de las Garantías del Debido Proceso Legal. Opinión Consultiva OC-16/99 de 1 de octubre de 1999. Serie A No. 16.

"Otros Tratados" Objeto de la Función Consultiva de la Corte (artículo 64, Convención Americana sobre Derechos Humanos). Opinión Consultiva OC-1/82 del 24 de septiembre de 1982. Serie A No. 1.

Titularidad de derechos de las personas jurídicas en el sistema interamericano de derechos humanos (Interpretación y alcance del artículo 1.2, en relación con los artículos 1.1, 8, 11.2, 13, 16, 21, 24, 25, 29, 30, 44, 46, y 62.3 de la Convención Americana sobre Derechos Humanos, así como del artículo 8.1 A y $B$ del Protocolo de San Salvador). Opinión Consultiva OC-22/16 del 26 de febrero de 2016. Serie A No. 22. 
Casos contenciosos

Caso Bámaca Velásquez vs. Guatemala. Reparaciones y Costas.

Sentencia del 22 de febrero de 2002. Serie C No. 91.

Caso Chitay Nech y otros vs. Guatemala. Excepciones Preliminares, Fondo, Reparaciones y Costas. Sentencia del 25 de mayo de 2010. Serie C No. 212.

Caso Comunidad Garífuna de Punta Piedra y sus miembros vs.

Honduras. Excepciones Preliminares, Fondo, Reparaciones y Costas. Sentencia del 8 de octubre de 2015. Serie C No. 304.

Caso Comunidad Garífuna Triunfo de la Cruz y sus miembros vs.

Honduras. Fondo, Reparaciones y Costas. Sentencia del 8 de octubre de 2015. Serie C No. 305.

Caso Comunidad Indígena Sawhoyamaxa vs. Paraguay. Fondo,

Reparaciones y Costas. Sentencia del 29 de marzo de 2006.

Serie C No. 146.

Caso Comunidad Indígena Xákmok Kásek vs. Paraguay. Fondo,

Reparaciones y Costas. Sentencia del 24 de agosto de 2010. Serie C No. 214.

Caso Comunidad indígena Yakye Axa vs. Paraguay. Fondo, Reparaciones y Costas. Sentencia del 17 de junio de 2005. Serie C No. 125.

Caso de la Comunidad Mayagna (Sumo) Awas Tingni vs. Nicaragua. Fondo, Reparaciones y Costas. Sentencia del 31 de agosto de 2001. Serie C No. 79

Caso de la Comunidad Moiwana vs. Surinam. Excepciones Preliminares, Fondo, Reparaciones y Costas. Sentencia del 15 de junio de 2005. Serie C No. 124.

Caso de las comunidades afrodescendientes desplazadas de la Cuenca del Río Cacarica (Operación Génesis) vs. Colombia. Excepciones Preliminares, Fondo, Reparaciones y Costas. 
Sentencia del 20 de noviembre de 2013. Serie C No. 270. Caso de los Pueblos Indígenas Kuna de Madungandí y Emberá de Bayano y sus miembros vs. Panamá. Excepciones Preliminares, Fondo, Reparaciones y Costas. Sentencia del 14 de octubre de 2014. Serie C No. 284.

Caso del Pueblo Saramaka vs. Surinam. Excepciones Preliminares, Fondo, Reparaciones y Costas. Sentencia del 28 de noviembre de 2007. Serie C No. 172.

Caso Fernández Ortega y otros vs. México. Excepción Preliminar, Fondo, Reparaciones y Costas. Sentencia del 30 de agosto de 2010. Serie C No. 215.

Caso Ivcher Bronstein vs. Perú. Fondo, Reparaciones y Costas. Sentencia del 6 de febrero del 2001, Serie C No. 74.

Caso López Álvarez vs. Honduras. Fondo, Reparaciones y Costas. Sentencia del 1 de febrero de 2006. Serie C No. 141.

Caso Masacre Plan de Sánchez vs. Guatemala. Fondo. Sentencia del 29 de abril de 2004. Serie C No. 105.

Caso Masacres de Río Negro vs. Guatemala. Excepción Preliminar, Fondo, Reparaciones y Costas. Sentencia del 4 de septiembre de 2012. Serie C No. 250.

Caso Miembros de la Aldea Chichupac y comunidades vecinas del Municipio de Rabinal vs. Guatemala. Excepciones Preliminares, Fondo, Reparaciones y Costas. Sentencia del 30 de noviembre de 2016. Serie C No. 328.

Caso Norín Catrimán y otros (Dirigentes, miembros y activista del Pueblo Indígena Mapuche) vs. Chile. Fondo, Reparaciones y Costas. Sentencia del 29 de mayo de 2014. Serie C No. 279. Caso Pueblo Indígena Kichwa de Sarayaku vs. Ecuador. Fondo y reparaciones. Sentencia de 27 del junio de 2012. Serie C No. 245. 
Caso Pueblos Kaliña y Lokono vs. Surinam. Fondo, Reparaciones y Costas. Sentencia del 25 de noviembre de 2015. Serie C No. 306.

Caso Rosendo Cantú y otra vs. México. Excepción Preliminar, Fondo, Reparaciones y Costas. Sentencia del 31 de agosto de 2010. Serie C No. 216.

Caso Tibi vs. Ecuador. Excepciones Preliminares. Fondo, Reparaciones y Costas. Sentencia del 7 de septiembre de 2004. Serie C No. 114.

Caso Tiu Tojín vs. Guatemala. Fondo, Reparaciones y Costas. Sentencia del 26 de noviembre de 2008. Serie C No. 190.

Caso Trabajadores de la Hacienda Brasil Verde vs. Brasil. Excepciones Preliminares, Fondo, Reparaciones y Costas. Sentencia del 20 de octubre de 2016. Serie C No. 318.

Caso Yatama vs. Nicaragua. Excepciones Preliminares, Fondo, Reparaciones y Costas. Sentencia del 23 de junio de 2005. Serie C No. 127.

Supervisión de cumplimiento

Resolución de Supenisión de Cumplimiento de Sentencia, Caso de la Comunidad Mayagna (Sumo) Awas Tingni, 3 de abril de 2009.

Medidas provisionales

Asunto Colotenango respecto Guatemala. Medidas Provisionales. Resolución de la Corte Interamericana de Derechos Humanos del 22 de junio de 1994.

Asunto Colotenango respecto Guatemala. Medidas Provisionales. Resolución de la Corte Interamericana de Derechos Humanos del 12 de julio de 2007. 
Asunto Pueblo Indígena Kankuamo respecto Colombia. Medidas

Provisionales. Resolución de la Corte Interamericana de Derechos Humanos del 5 de julio de 2004.

Asunto Pueblo Indígena Kankuamo respecto de Colombia. Medidas Provisionales. Resolución de la Corte Interamericana de Derechos Humanos del 21 de noviembre de 2011.

Asunto Pueblo Indígena Sarayaku respecto Ecuador. Medidas Provisionales. Resolución de la Corte Interamericana de Derechos Humanos del 6 de julio de 2004.

Asunto Serech y Saquic respecto Guatemala. Medidas Provisionales. Resolución de la Corte Interamericana de Derechos Humanos del 28 de junio de 1996.

Asunto Serech y Saquic respecto Guatemala. Medidas Provisionales. Resolución de la Corte Interamericana de Derechos Humanos del 19 de setiembre de 1997.

Caso de la Comunidad Mayagna (Sumo) Awas Tingni respecto Nicaragua. Medidas Provisionales. Resolución de la Corte Interamericana de Derechos Humanos del 6 de septiembre de 2002.

Caso de la Comunidad Mayagna (Sumo) Awas Tingni respecto Nicaragua. Medidas Provisionales. Resolución de la Corte Interamericana de Derechos Humanos de 26 de noviembre de 2007.

Caso Masacre Plan de Sánchez (Salvador Jerónimo y otros) respecto Guatemala. Medidas Provisionales. Resolución del Presidente de la Corte Interamericana de Derechos Humanos del 30 de julio de 2004.

Caso Masacre Plan de Sánchez (Salvador Jerónimo y otros) respecto Guatemala. Medidas Provisionales. Resolución de la Corte Interamericana de Derechos Humanos del 14 de junio de 2005. Corte IDH, Asunto Integrantes de la Comunidad Indígena de Choréachi respecto de México. Solicitud de medidas provisionales. 
Resolución de la Corte Interamericana de Derechos Humanos del 25 de marzo de 2017.

Sistema Africano de Derechos Humanos

Comisión Africana de Derechos Humanos y de los Pueblos

ACHPR, Centre for Minority Rights Development (Kenya) and Minority Rights Group International on Behalf of Endorois Welfare Council vs. Kenya, 276/2003.

ACHPR, The Social and Economic Rights Action Center and the Center for Economic and Social Rights vs. Nigeria, Communications No. 155/96.

Corte Africana de Derechos Humanos

ACoHPR, African Commission on Human and People's Rights (Ogiek) vs. Kenya, Application No. 006/2012, Sentencia del 26 de mayo de 2017.

Sistema Europeo de Derechos Humanos

Comisión Europea de Derechos Humanos

Application No. 27033/95, Caso Könkämä y otros 38 miembros de la Villa Saami vs. Suecia, Admisibilidad del 25 de noviembre de 1996.

Corte Europea de Derechos Humanos

Caso de la Villa Sami Handolsdalen vs. Suecia, Application No. 39013/04, Sentencia del 30 de marzo de 2010. 
Comité de Derechos Humanos de las Naciones Unidas

Caso Ángela Poma Poma vs. Perú, 29 de marzo de 2009, CCPR/ C/95/D/1457/2006.

Caso Apirana Mahuika et al. vs. Nueva Zelanda, 27 de octubre de 2000, CCPR/C/70/D/547/1993.

Caso George Howard vs. Canadá, 26 de julio de 2005, CCPR/ C/84/D/879/1999.

Caso Lovelance vs. Canadá, 30 de julio de 1981, CCPR/ $\mathrm{C} / 13 / \mathrm{D} / 24 / 1977$.

Caso Mavlonov and Sa'di vs. Uzbekistan, 19 de marzo de 2009, CCPR/C/95/D/1334/2004.

Ominayak y Lake Lubicon Band vs. Canadá, 26 de marzo de 1990, CCPR/C/38/D/167/1984.

Vicente et al. vs. Colombia, 29 de julio de 1997, CCPR/ $\mathrm{C} / 60 / \mathrm{D} / 612 / 1995$.

Relatores de Naciones Unidas

Consejo Económico y Social, Cuestiones Indígenas, Derechos Humanos y Cuestiones Indígenas, Informe del Relator Especial sobre la Situación de los Derechos Humanos y las Libertades Fundamentales de los Indígenas, Sr. Rodolfo Stavenhagen. Adición-Misión a Colombia, E/CN.4/2005/88/Add.2, 10 de noviembre de 2004.

Relator Especial sobre Pueblos Indígenas, Sr. James Anaya, Las industrias extractivas y los pueblos indígenas, 1 de julio de 2013, A/HRC/24/41.

Observaciones generales

Comité CEDAW, Recomendación General No. 25, Medidas especiales de carácter temporal (párrafo 1 del artículo 40. de la 
Convención sobre la Eliminación de Todas las Formas de Discriminación contra la Mujer), 2004, 30 Periodo Ordinarios de Sesiones.

Comité de Derechos Humanos, Observación General No. 12 (Derecho a la libre determinación), 12 de abril de 1984.

Comité de Derechos Humanos, Observación General No. 23 (Derechos de las minorías, art. 27 del Pacto) 26 de abril de 1994, CCPR/C/21/Rev.1/Add.5.

Comité de Derechos Económicos, Sociales y Culturales, Observación general No. 7 , El derecho a una vivienda adecuada (párrafo 1 del artículo 11 del Pacto): los desalojos forzosos (16 Periodo de Sesiones, 1997), U.N. Doc. E/1999/22, (1997).

Comité de Derechos Económicos, Sociales y Culturales, Observación General No. 12, El derecho a una alimentación adecuada (artículo 11) (20 Periodo de Sesiones, 1999), U.N. Doc. E/C.12/1999/5 (1999).

Comité de Derechos Económicos, Sociales y Culturales, Observación General No. 14, El derecho al disfrute del más alto nivel posible de salud (artículo 12 del Pacto Internacional de Derechos Económicos, Sociales y Culturales) (22 Periodo de Sesiones, 2000), U.N. Doc. E/C.12/2000/4 (2000).

Comité de Derechos Económicos, Sociales y Culturales Observación General No. 15, Aplicación del Pacto Internacional de los Derechos Económicos, Sociales y Culturales, El derecho al agua (artículos 11 y 12 del Pacto) (29 Periodo de sesiones, 2002), U.N. Doc. HRI/GEN/1/Rev.7 at 117 (2002).

Comité de Derechos Económicos, Sociales y Culturales, Observación General No. 17, Aplicación del Pacto Internacional de los Derechos Económicos, Sociales y Culturales, El derecho de toda persona a beneficiarse de la protección de los intereses morales y materiales que le correspondan por razón de las producciones científicas, literarias o artísticas de que sea autor(a) 
(artículo 15 del Pacto, apartado c) párrafo 1) (35 Periodo de Sesiones, 2005), U.N. Doc. E/C.12/GC17 (2006).

Comité de Derechos Económicos, Sociales y Culturales, Observación General No. 21, El derecho a participar en la vida cultural (artículo 15, párrafo 1 a) del Pacto), (43 Periodo de Sesiones, 2009), U.N. Doc. E/C.12/GC/21/Rev.1 (2010).

Comité de Derechos Económicos, Sociales y Culturales, Observación General No. 22, El derecho a la salud sexual y reproductiva (artículo 12), E/C.12/GC/22, 4 de marzo de 2016.

Comité de Derechos Económicos, Sociales y Culturales, Observación General No. 23, El derecho a condiciones favorables de trabajo (artículo 7), E/C.12/GC/23, 26 de abril de 2016.

Comité de los Derechos del Niño, Observación General No. 11: Los niños indígenas y sus derechos en virtud de la Convención de los Derechos del Niño, CRC/C/GC/11, 12 de febrero de 2009.

Comité para la Eliminación de la Discriminación Racial, Recomendación General No. 23, relativa a los derechos de los pueblos indígenas, 1997.

Comité para los Derechos de las Personas con Discapacidad, Observación General No. 3, Sobre mujeres y niñas con discapacidad, 2 de septiembre de 2016, CRPD/C/GC/3.

\section{Tratados Internacionales}

Carta Africana de Derechos Humanos y de los Pueblos. Carta de las Naciones Unidas de 1945.

Convención Americana sobre Derechos Humanos.

Convención para la Prevención y Sanción del Delito de Genocidio. Convenio 169 de la Organización Internacional del Trabajo.

Convenio Europeo de Derechos Humanos.

Declaración Universal de Derechos Humanos. 
Pacto Internacional de los Derechos Civiles y Políticos.

Pacto Internacional de los Derechos Económicos, Sociales y Culturales.

Otras fuentes de información

Audiencia pública ante la Comisión IDH durante el 144 Periodo de Sesiones sobre Discriminación Contra las Mujeres Indígenas en las Américas, 28 marzo 2012, http://www.oas.org/ es/cidh/audiencias/hearings.aspx?lang $=$ es $\&$ session $=125 \& p a$ ge $=2$.

Audiencia Pública ante la Corte Interamericana del Caso Kichwa de Sarayaku vs. Ecuador, http://www.corteidh.or.cr/index.php/ es/al-dia/galeria-multimedia?start $=40$.

“El Paraguay devolvió a Yakye Axa su tierra”, http://www.tierraviva. org.py/site/noticias_int/22.

http://www.ilo.org/dyn/normlex/es/f?p=NORMLEXPUB:11300:0:: NO::P11300_INSTRUMENT_ID:312314.

Nota de prensa de la Corte Suprema de Justicia de Paraguay, Realizan aclaración sobre sentencias, 24 de febrero de 2015, http://www.pj.gov.py/notas/10638-realizan-aclaracion-sobresentencias.

Oficina Internacional del Trabajo, Las poblaciones Indígenas, Ginebra, Oficina Internacional de Trabajo, 1953.

ONU, Relatoría Especial sobre los Derechos de los Pueblos Indígenas, Informes Anuales, http://www.ohchr.org/SP/Issues/ IPeoples/SRIndigenousPeoples/Pages/AnnualReports.aspx.

ONU, Relatoría Especial sobre los Derechos de los Pueblos Indígenas, Reportes de Países, http://www.ohchr.org/SP/Issues/ IPeoples/SRIndigenousPeoples/Pages/CountryReports.aspx. 
Página de la Relatoría de Derechos de los Pueblos Indígenas de la CIDH, http://www.oas.org/es/cidh/indigenas/decisiones/cidh. asp.

Peritaje rendido por Rosalina Tuyuc en la Audiencia pública celebrada el 19 y 20 de junio de 2012, http://vimeo.com/album/1983401.

Video de audiencia pública compuesta de supervisión de cumplimiento al respecto en noviembre de 2011, http://vimeo. com/32480699. 
Los derechos de los pueblos indígenas y tribales en los sistemas de derechos humanos, editado por el Instituto de Investigaciones Jurídicas de la UNAM y la Comisión Nacional de los Derechos Humanos, se terminó de imprimir en septiembre de 2017 en los talleres de GVG GRUPO GRÁFICO, S. A. de C. V., Leandro Valle núm. 14-C, colonia Centro, Delegación Cuauhtémoc, C. P. 06010, Ciudad de México. La edición consta de 2,000 ejemplares. 